\title{
LA SUCESION A LOS BIENES DE JUAN ANTONIO LLORENTE, EN PARÍS
}

\author{
POR
}

\author{
ENRIQUE DE LA LAMA
}

Universidad de Navarra

\section{ReSUMEN}

Llorente, uno de los más afamados críticos de la Inquisición de España, afrancesado de alta responsabilidad y bien conocido en su mismo semblante físico por el retrato que le hizo Goya, falleció sin hacer testamento. El presente trabajo estudia detalladamente los documentos notariales de la sucesión «ab intestato», que permiten conocer su biblioteca y sus enseres personales, así como la noticia de una hija natural nacida en Francia durante su exilio.

PALABRAS ClAVE: Inquisición, Bibliografia, Catolicismo ilustrado, Notariado.

\section{AbSTRACT}

Llorente, one of the most famous critics of the Spanish Inquisition, «afrancesado» in top responsibility and well known in his own physical feature wich Goya made of him, died without leaving his last will. The present work studies in detail the notary documents referring to "succesio ab intestato», wich permit to know his library, his personal belongings as well as information about an illegitimate daughter born in France during his exile.

KEY WORDS: Inquisition, Bibliography, Enlightened catolicism, Notarial style.

Yo tengo derecho a que las personas imparciales y desnudas de pasión juzguen mi causa en el tribunal de la opinión pública.

Inquisidores contra la Inquisición Hispania Sacra 55 (2003) 
La diana que se desea acertar —en cualquier trabajo histórico- es siempre el hombre. Su rostro. Su alma. Su vida. Y, por eso, su muerte, que es el suceso de los sucesos: acaecimiento nunca trivial. El único instante total, definitivo e inexorable, que deja en pos de sí la huella más elocuente de la existencia concluida.

\section{LO QUE CONDENA LA VERDAD SINCERA}

A Juan Antonio Llorente le sobrevino el fallecimiento de modo súbito. Era el 5 de febrero de 1823 «a cosa de las dos y media de la tarde», «de resultas de un ataque apopléjico por cuyo motivo no pudo recibir los Santos Sacramentos» - dice el acta de defunción-. Para el Nuncio Giustiniani - retirado en Burdeos por la crudeza de la situación político-religiosa en España- la muerte del «demasiado célebre señor Llorente ... es un visible y tremendo ejemplo de la Justicia divina». Y completa la noticia añadiendo que «dos días antes de su espantoso fin» había visto luz pública un opúsculo de Llorente titulado Notas al dictamen de la comisión encargada del arreglo definitivo del clero, con el que se anima a las Cortes a un abierto Cisma ${ }^{1}$.

No faltará quien se rasgue las vestiduras ante las palabras de Giustiniani, personalidad notablemente propensa a expresiones dramáticas. Pero, aparte la discutible retórica del Nuncio de España, resulta incontestable que la noticia del fallecimiento del eclesiástico riojano impresionó en los ambientes de la Villa y Corte y también y, sobre todo, en Francia donde las páginas de sus últimos libros - Historia crítica de la Inquisición de España, Aforismos Políticos, Retrato político de los Papas - le habían hecho acreedor a un ambiguo

1 Despacho Giustiniani-Consalvi, Notizie ecclesiastiche di Spagna, Bordeaux 22 febbraio 1823. ASV SS, 249 (1823) fasc. $2^{\circ}$ : «Quella (morte) del troppo celebre Sigr. Llorente V.E. l'avrà già saputa dai giornali francesi; essa è un visibile, tremendo esempio della Giustizia Divina. Due giorni prima dello spaventevole suo fine, il Sigr. Llorente avea pubblicato un' opuscolo sotto il titolo di Osservazioni sul nuovo Piano del Clero, per animare le Cortes ad' un aperto scisma. Egli è spirato senza veder coronati i suoi voti; ma se per l' imperscrutabili decreti della Providenza, la rivoluzione di Spagna gli soppravive ancora per qualche tempo, 1 ' opera dell empietà verrà senza dubbio consumata e il Piano del Clero, come già accennai in altro mio dispaccio a V. E., per non sgomentare il popolo, s' introdurrà quasi furtivamente nella Chiesa di Spagna in altrettanti separati decreti, quanti -a un dipresso- sono i principali punti che abbraccia. Il decreto già pronunziato per la vacanza delle sedi de' Vescovi espulsi o da esigliarsi in appresso, servirà di norma al partito giansenista pel successivo sviluppo di tutti i soui dissegni. Il salutare timore di una guerra straniera non a fatto che momentaneamente paralizzarli; ma se qualche inaspettato successo giunge su di ciò à rassicurarli, non vi sarà più ostacolo alcuno che li rattenga». Sirvan estas palabras de Giustiniani para evocar el contexto que rodeó el proceloso atardecer de Juan Antonio Llorente recién llegado a su patria. Y también para valorar la relevancia del discutido eclesiástico como mentor en las Cortes de lo que el Nuncio denomina como partido jansenista. A este partido pertenecían, entre otras personalidades, los también eclesiásticos Espiga y Muñoz Torrero.

Inquisidores contra la Inquisición

Hispania Sacra 55 (2003) 
reconocimiento: «Suetonio de la Inquisición» — seguimos estando ante la grandilocuencia decimonónica-, «calurosísimo defensor de las libertades eclesiásticas», escritor tolerante y culto «cuya filosofia razonable era precisamente el término opuesto a la que acaba de descubrir recientemente M. l'abbé Lamennais, quien, para llegar al conocimiento de lo verdadero, no admite - como es sabido- otra vía que el argumento de autoridad $»^{2}$. - Tales encomios dedicados al recién finado en una nota biográfica y necrológica tienen, sin embargo, su contrapeso. El autor, A. Mahul - amigo de Llorente y, por lo tanto, no sospechoso de animadversión - reconoce defectos patentes en el estilo del eclesiástico español que disminuyen su crédito - negando su savoir faire- como escritor y hombre de letras. Y no sólo defectos externos que restan elegancia, sino quiebras de criterio en merma de su coherencia moral. «Esta obra - dice refiriéndose a Portrait politique des Papes - es un trabajo de gran erudición; pero cabe objetar que proporcionará lamentable entretenimiento a cuantos han quedado escandalizados por los abusos contra la religión y por los pecados de sus sacerdotes. El autor admite una porción de datos de más que dudosa autenticidad, principalmente la historia de la pretendida papisa Juana, cuyo origen de fuente apócrifa está ya hoy suficientemente demostrado; debemos reconocer con dolor que el tema de la obra, el fin pretendido y el mismo tono adoptado desdicen de la condición de un sacerdote católico, cuyo honor es en todo caso inseparable del de la Sede Apostólica; salvo, naturalmente, el derecho inamisible a combatir los errores que pudieran ampararse bajo capa de tan gran autoridad» ${ }^{3}$. Y amplía más adelante Mahul refiriéndose, por un lado, a la nobleza de la causa que Llorente sirvió y, por otro, al desacierto con que la sirvió: «La religión, la política y la historia fueron alternativamente deudoras a M. Llorente de servicios importantes; algunas veces también tuvieron que lamentar sus errores. - Sin duda - continúa - él ha sido benemérito de la religión por combatir y desenmascarar el fanatismo sanguinario que ha mancillado su pureza. Ha debido de atraer a su causa muchos espíritus generosos que se habían ale- jado de ella por culpa de odiosas y falsas interpretaciones; ha contribuido a curarla de esta lepra de la superstición, que tantas veces se adhiere a sus obras: pero, dedicado demasiado exclusivamente a la persecución de los abusos modernos, se le ha visto a veces ofender aquellas tradiciones de origen apostólico que el verdadero católico respeta tanto como los dogmas de su fe. Acostumbrado a remontarse a las fuentes históricas y a verificarlas rigurosamente, ha olvidado en ocasiones que, en la comunión de la Iglesia, hay establecimientos de costumbres y de hechos cuya discusión no ha sido dejada a la libre interpre-

2 A. MAHUL, Notice biographique sur D. J. Antoine Llorente, auteur de l'Histoire de l'Inquisition, l'un des collaborateurs de la «Revue Encyclopédique» como necrológica tras conocer el fallecimiento del clérigo español. Revue Encyclopédique, XVIII (avril 1823) 29.

3 Ibidem, 41. 
tación de cada cual, sino que para nosotros los católicos son y permanecen irrevocablemente fijas por esta tradición constante de las iglesias, que nosotros contamos en el número de las reglas de nuestra fe» ${ }^{4}$.

Y refiriéndose ahora a aspectos de rango profesional que afectan a la personalidad de Llorente y a su prestigio como escritor, Mahul concluye: «M. Llorente poseía un vasto saber, principalmente en materias eclesiásticas e históricas; pero su erudición no tenía esa precisión rigurosa que los sabios de Inglaterra, de Francia y de Alemania exigen hoy en día. Su espíritu no carecía de perspicacia y de método; pero el arte de componer un libro, tal como nosotros lo entendemos en Francia, le era desconocido. Su estilo en su lengua materna, en la medida en que nos es permitido valorarlo, tenía corrección y claridad, pero no se hacía notar por ninguna cualidad brillante; hablaba el francés penosamente, poco correctamente y así también lo escribía. Lo que él ha publicado en nuestra lengua ha debido ser necesariamente revisado por personas a quienes este idioma les era familiar .... $»^{5}$.

A este enjuiciamiento negativo se adhería, consciente o inconscientemente, Alcalá Galiano en 1833 en uno de aquellos artículos que publicó entre abril y junio de ese año en la revista londinense «The Athenaeum». Se refería él a la Historia de la Inquisición en la que reconocía méritos como «aportación a la historia de las instituciones religiosas y del entendimiento humano». Afirmaba que, «antes de que saliera a luz, poco era lo que se sabía del famoso tribunal, aun en España. Cuando la abolieron Napoleón y las Cortes -es decir los dos contendientes por la supremacía política de España - la falta de documentos impidió la publicación de otra cosa que vagas generalidades respecto a sus misteriosos procedimientos». Ahora bien, Alcalá Galiano no se queda corto en el contrapeso: «La historia de la Inquisición resultó, como cabía esperar, un libro curioso. Pero mal escrito. Llorente había nacido en las provincias vascongadas, donde, como es bien sabido, se habla una lengua totalmente diferente de la castellana, y aun de todas las europeas, hasta el punto que entre españoles concordancia vizcaína es sinónimo de sintaxis absurda. Puede que esto sea un prejuicio, pero es verdad respecto a Llorente. La historia de la Inquisición, sus Memorias históricas sobre la revolución de España, su ingeniosísima obra acerca del autor de Gil Blas, y muchos otros trabajos fruto de su infatigable laboriosidad, no puede decirse que estén escritos en castellano. El menos

\footnotetext{
4 Ibidem, 43.

5 Ibidem, 44. En el mismo sentido se expresaba El Independiente -periódico exaltado- en una recensión de los Aforismos políticos publicada el 19 de enero de 1822: «En la traducción se notan más corrección y elegancia que las que suele emplear Llorente en sus escritos, menos atento a esta parte $\tan$ necesaria que a enumerar sus títulos y hacer alarde de sus obras». Cfr. G. DUFOUR, Juan Antonio Llorente en France (1813-1822). Contribution à l'étude du Libéralisme chrétien en France et en Espagne au début du XIX siècle, Droz, Genève 1982, 285, n. 99
}

Inquisidores contra la Inquisición

Hispania Sacra 55 (2003) 
exigente lector español, por mucho que le satisfaga la materia contenida en sus obras, no dejará de sentirse herido por las peculiaridades del estilo» ${ }^{6}$. Está muy claro que ni Llorente era vasco - isi levantara la cabeza...! - ni su estilo es tan descortés y reñido con la limpieza literaria como dice Alcalá Galiano. Ahora bien - algo tiene el agua cuando la bendicen-, también Alcalá Galiano, nada sospechoso de intolerancia antiliberal, escribe a propósito del posicionamiento doctrinal del sacerdote afrancesado: «Los últimos años de su vida los consumió Llorente en una activa lucha contra las pretensiones de la Santa Sede. Aunque había escrito contra los patriotas y abrazado el partido opuesto a las Cortes, al triunfar aquellos en 1820 se convirtió, a favor de una reforma de la Iglesia, en uno de sus más celosos defensores». Y luego, más explícitamente, lo compara a Villanueva, famoso por su sectarismo y su controvertida misión como embajador de España ante la Santa Sede: «En la guerra teológica emprendida por miembros de la Iglesia católica contra su cabeza visible, el romano Pontífice, Llorente tuvo un entusiasta y no menos celebrado compañero, que le igualaba en celo y erudición y lo superaba en mucho como escritor» ${ }^{7}$.

No exagera, por eso, Menéndez Pelayo cuando considera la Historia crítica como un libro mal hecho, que denota la seca fantasía de su autor, «relación ramplona y desordenada, en estilo de proceso, oscura e incoherente, atestada de repeticiones y de fárrago, sin arte alguno de composición, ni de dibujo ni de colorido, sin que el autor acierte nunca a sacar partido de un personaje o de una situación interesante.... ${ }^{8}$.

Pero el estilo no lo es todo. Hemos conocido en la historia personalidades que con toscas maneras, con alardes aparentemente desdeñables y rudeza verbal eran capaces de conmover y arrastrar en pos de sí gentes numerosas, ejerciendo un liderazgo innovador de generaciones. Un pobre diablo puede empuñar y blandir la enseña de la «santa libertad» y caminar delante de los sabios y de los espíritus fuertes que habían hecho de su rabia contenida un tópico social inoperante. En las páginas de Llorente hay una levadura concitadora, capaz de desazonar mentes jóvenes y lúcidas como la de don Marcelino Menéndez Pelayo, pese a su afirmación de que «aquella obra inicua (y él se refiere a la Historia de la Inquisición), en fuerza de ser indigesta, resultó menos perniciosa, porque pocos, sino los eruditos, tuvieron valor para leerla hasta el fin» ${ }^{9}$. Lo cierto es que el ilustre polígrafo montañés, cuando escribía durante su superdotada adolescencia la Historia de los heterodoxos, tenía ante sus ojos la goyesca

${ }^{6}$ A. AlCalÁ Galiano, Literatura española del siglo XIX. De Moratín a Rivas, Traducción, introducción y notas de Vicente LLORENS, Alianza, Madrid 1969, 54-55.

7 Ibidem, 55 y 56.

8 M. MENÉnDEZ Pelayo, Historia de los heterodoxos españoles, VI, en Obras Completas, ed. dirigida por Angel González Palencia, XL, Santander 1948, 19.

9 Ibidem. 
y embrujada mirada de Llorente: «Tantas veces - confiesa- hemos tenido que hablar de la Historia de la Inquisición en este libro, que en cierto modo pude considerarse como una refutación de ella» ${ }^{10}$.

El juicio de Menéndez Pelayo concordaba, por lo tanto, con Mahul y con Alcalá Galiano, si bien el joven escritor santanderino no le reconoce mérito alguno. Ahí estuvo principalmente su exceso: del que más tarde debió arrepentirse - no sé con qué fervor. En todo caso tal ha sido a lo largo del siglo XIX, la fama de Llorente como escritor. Nadie se ha arriesgado a romper una lanza por la opinión contraria.

Pero, entre tanto, menudearon las ediciones de la Historia crítica y se fueron olvidando las demás páginas de aquella pluma áspera e infatigable: páginas apasionadas - aunque sin brillo ni retórica elegante-. M. Serrano y Sanz en su libro de autobiografias y memorias que publicó en la colección «Nueva Biblioteca de Autores Españoles» bajo la significativa dirección de Menéndez Pelayo enjuiciaba -iniciado ya el siglo $\mathrm{xx}$ - la Historia de la Inquisición en estos términos: «De muy diversos modos ha sido juzgada la personalidad de $\mathrm{D}$. Juan Antonio Llorente, no sólo desde el punto de vista literario, mas también en lo referente a su vida y opiniones. Nada tiene de particular el que se granjease un odio casi universal en España quien puso con sus escritos la segur al tronco del carcomido árbol inquisitorial, obra acaso la más laudable que realizó. De la Historia de la Inquisición han dicho unos que era monumento de gran valor, otros lo han reputado libelo calumnioso; opinión falsa, pues si bien contiene multitud de errores, debe considerarse que la escribió sin tener a la vista los innumerables papeles del Santo Oficio que en otro tiempo examinó. Con todo, las últimas investigaciones, hechas algunas de ellas por un jesuita, el P. Fidel Fita, le van dando la razón en muchas cosas». Este enjuiciamiento significaba un cambio de signo aunque quedaban años para que se produjese la beneficiosa reconciliación de las corrientes de estudiosos de la inquisición por los años setenta.

\section{UNA DE LAS DOS ESPAÑAS...}

No obstante, para Serrano, como para tantos compatriotas, la heterodoxia política resultaba más imperdonable que la misma heterodoxia teológica: «Más difícil es y será siempre vindicar a Llorente de otro pecado más cierto: la traición a su patria.... ${ }^{11}$. Pero ¿en qué consistía esa traición, sino en el afrancesamiento?

\footnotetext{
10 Ibidem, 18-19.

11 M. SERRANO Y SANZ, Autobiografias y Memorias coleccionadas e ilustradas, «Nueva Bublioteca de Autores Españoles» 2, Bailly/Balliére, Madrid 1905, p. CLIV.

Inquisidores contra la Inquisición

Hispania Sacra 55 (2003)
} 
Cuando Serrano habla, han transcurrido más de ochenta años a partir del día en que Llorente volvió a entrar en España después de diez años de destierro.

A lo largo del siglo XIX se consolidan, hasta llegar a ser fractura espiritual, las «dos Españas». Esa división es más profunda que la sola ruptura afrancesada. Aunque tiene -en casos - relación con ella. Con penetrante sagacidad ha hecho notar Gérard Dufour el significado de la contienda intestina que se desarrollaba entre los españoles que compartían el dolor del destierro en la capital francesa, y que se exponía a la luz pública fuera de la patria: «... dos grupos se oponen y se espían mutuamente en el seno de la colonia española de París: los antiguos afrancesados y los serviles que orbitaban, según parece, en torno a la embajada. Las «dos Españas» se enfrentaban en París» ${ }^{12}$. De hecho, cuando el día 25 de diciembre de 1822 Llorente atravesó la frontera de Irún, la recepción que se le tributó parece haber sido calurosa: autoridades y pueblo, jóvenes vascos de la provincia que acababan de enterarse de la llegada del desterrado «se reunieron y le ofrecieron una gran serenata mientras cenaba» ${ }^{13}$.

El gobierno del Trienio alcanzaba su cúspide de exaltación y la llegada de Llorente era consonante con el triunfo de los exaltados en el gobierno de Madrid y en las Cortes. «Queremos que sepa España con cuántos descamisados puede contar en el Congreso» - se lee por aquellos días en un libro publicado bajo las planchas de «El Zurriago»- Y en la lista de descamisados se incluye entre otros a Llorente ${ }^{14}$. Se distinguía, pues, a Llorente como a personalidad emblemática en aquel momento de revolución parlamentaria acompañada de activa fermentación social - Sociedad Landaburiana, Comuneros, Carbonarios, que se infiltraban en las filas políticas exaltadas ${ }^{15}$ - Tras diez años de exilio, el repatriado disfrutó en sus últimas semanas del consuelo -llamémoslo asípropio de un triunfo moral: pudo pensar, ante el espectáculo de aquellas breves semanas de enero, que a su incomprendido reformismo le había llegado por fin la hora de levantarse en alborada.

Triunfo efímero. No sólo porque los acontecimientos políticos iban a dar un quiebro. Sino porque el proscrito, que ahora disfrutaba de la miel del retorno, llevaba clavado en su cerebro el dardo definitivo. Tal vez nada envejece tanto como la magnitud de esperanzas con cosecha de desengaños. Y de desengaños, Llorente llevaba un saco sobre sus espaldas. Alcalá Galiano ha dejado un testimonio impresionante: «Llegó a Madrid ya muy viejo, con la salud destrozada, pero con todas sus energías intactas. Tuvo la suerte de asistir pocos días

\footnotetext{
12 G. Dufour, c., 117.

13 Constitutionnel, 4 janvier 1823.

14 Condiciones y semblanzas de 1822-1823, imp. de El Zurriago, 1822, cit. por Iris M. ZAVALA, Masones, comuneros y carbonarios, Siglo XXI de España, Madrid 1971, 47, n. 24 ad finem.

${ }^{15}$ Cfr. Iris M. ZAVALA, c., 112-122.
} 
después de su llegada a aquella famosa sesión de las Cortes en donde las notas dirigidas por el Congreso de Verona fueron objeto de animada e interesante discusión. Era impresionante ver a aquel anciano, el rostro ajado brillando de exaltación, contemplando al cabo de diez años de destierro con sus propios ojos el alentador espectáculo de una asamblea deliberativa española, y oyendo los acentos de sus patrióticos oradores» ${ }^{16}$.

La presencia moral de Llorente en las Cortes venía siendo un hecho. Sus páginas del Proyecto de una constitución religiosa como parte de la civil nacional y su testimonio episcopalista, anti-curial y anti-romano, su hispanismo - entendido el término en analogía con el galicanismo francés, según dijo lúcidamente Menéndez Pelayo- contribuían ahora al apoyo de una Iglesia Nacional. El propio Llorente había difundido la explicación de su retorno: expulsión de Francia por sus escritos doctrinalmente subversivos. O sea, principalmente, por el Portrait politique des Papes y por las intrigas del «Nuncio (en París), auxiliado por el Arzobispo y el Gran Limosnero» ${ }^{17}$.

\section{EL IDEAL CARBONARIO}

Las páginas de Dufour sobre la actividad subversiva de Llorente en los últimos tres años de su permanencia en Francia constituyen una pista fiable para conocer la verdadera razón de su extrañamiento ${ }^{18}$. Expulsión por colaboración subversiva con la Sociedad Carbonaria.

Llorente no fue masón. Por lo menos, no está probado que lo fuese ni se puede aducir indicio alguno que avale seriamente esta etiqueta ${ }^{19}$. Su vinculación con la Carbonería es otra cosa. Mahul - a quien ya conocemos por su necrológica de Llorente- era también vigilado y, de hecho, iba a ser detenido y encarcelado acusado de pertenenecer a dicha sociedad secreta. De hecho, el Ministerio francés tenía tomada ya desde el 19 de octubre de 1822 - dos meses antes de la publicación de Portait politique des Papes- la decisión de expulsar a Llorente ${ }^{20}$. Por eso le venía vigilando e interceptando, cuando pudo, su correspondencia; asimismo siguió vigilando a sus parientes y amigos en los meses que siguieron a su fallecimiento. En todo caso, una masa económica tan magra como la del eclesiástico riojano - a juzgar por la herencia que dejóparece demostrar que su espionaje apenas pasó nunca del nivel propio del agi-

16 A. Alcalá Galiano, $c$., 55.

17 Post data de la carta Llorente-Amorós, París 12 de diciembre de 1822, cit. en G. DUFOUR, c., 337.

18 Cfr. G. Dufour, c., 335-357.

19 Cfr. G. Dufour, c., 193-200.

20 Cfr. la interesantísima información que da al respecto G. DUFOUR, c., 349-356.

Inquisidores contra la Inquisición

Hispania Sacra 55 (2003) 
tador, del confidente y soplón sin oportunidad alguna de marcarse un tanto apreciable en el negocio de las informaciones reservadas.

Si se tiene en cuenta su mentalidad y su sensibilidad, no es demasiado admirable que la tentación de la Carbonería hiciese mella en el arrumbado eclesiástico. En su biografia se percibe un déficit de romanticismo que la inspiración utópica del proyecto carbonario era capaz de colmar. Llorente había traducido su cansancio en una secularización encubierta. Secularización sua sponte. Se comprende, porque su trayectoria vocacional da mucho que pensar desde el comienzo - cuando es embocado hacia el sacerdocio por un destino familiar ineluctable - hasta la época final, cuando se ve desesperadamente encerrado, y sin amigos auténticos, como en el confuso espacio interior de una esfera de espejos. Y, entre esos dos extremos, están los largos años de lucha por superarse, siempre a la busca de una imagen socialmente reconocida, sorbiéndose los vientos para escalar la plataforma de la acomodada burguesía: éxito, ilustración, dinero y prestigio, poder. Y también, a su modo, el amor ilícito, saboreado a hurtadillas. Conflicto, pienso, entre un ethos a lo Tavira, pero sin inspiración - acomodado fría, tosca e inexpresivamente a la sensibilidad hispano-visigótica y a los primeros siglos cristianos-y un pathos revolucionario y sectario, rebeldía contra la estructura impuesta e ineludible. Entre sus bienes de París no hay ni un crucifijo, ni una imagen religiosa, ni libros de piedad. Sólo dos biblias - una de ellas, seguramente, en versión hugonote- y obras de Lactancio. Lo más vivo y palpitante de Llorente estaba a la contra: de ahí nacía su jansenismo de oportunidad - como talante de rechazo- y, también, sus filias y su colaboración carbonarias ${ }^{21}$.

En el santuario espiritual de las personalidades atormentadas - por no decir rebeldes, que tal vez es excesivo- no desaparece el recuerdo de la nobleza, de la belleza original. No me refiero aquí a la añoranza del «paraíso perdido». Hablo de esa hora primigenia que le es concedida a todo hombre como un amanecer: la limpieza de los primeros ojos sin experiencia de negaciones, de traiciones y de ira ${ }^{22}$. Y es aquí - en este santuario en que la personalidad forja sus opciones fundamentales - donde el ideal de la Carbonería pudo obtener el

21 Historias como la de Llorente resultan ya hoy imposibles -0 , por lo menos, distan mucho de ser frecuentes-: como también resulta inactual la atmósfera galdosiana de Doña Perfecta, o de Gloria o de La Familia de León Roch. Pero aquellos eran los tiempos. Las cosas son ya de otro modo, aun cuando el hombre sea siempre hombre y los problemas de falta de libertad psicológica y estructural se repitan en planos y encuadres distintos.

22 «Omne quod est, inquantum est et naturam habet aliquam, in bonum aliquod naturaliter tendit, utpote ex principio bono existens: quia semper effectus convertitur in suum principium». Summa Theologica, I, q.63, a.4 in c.- «Peccatum est contra naturalem inclinationem: ea vero quae contra naturam fiunt, ut in paucioribus accidunt; natura enim consequitur suum effectum vel semper vel ut in pluribus». Ibidem, a.9, in c. 
placet de don Juan Antonio: «porque los carbonarios muestran una fe sincera en la religión de Jesús, pero en la religión de Jesús tal como aparece en el Evangelio, exenta y libre de todos los elementos extraños que los teólogos le han ido añadiendo a lo largo de XVIII siglos. Son, pues, al mismo tiempo reformadores políticos y religiosos $\rangle^{23}$.

A comienzos de 1823, la atmósfera comunera de exultación y exaltación aceleraba emociones y la bóveda del Palacio de las Cortes se apretaba sobre los Padres de la Patria como un firmamento confuso, en anuncio de tormenta. El día 11 de enero, Alcalá Galiano y Agustín Argüelles rechazaron en sus discursos la presencia extranjera en España y cualquier intervención militar foránea, como la amagada - e incluso ya acordada - por el Congreso de Verona. El público enardecido rompió en aplausos - contra la costumbre siempre seguida hasta entonces por las Cortes Españolas, de escuchar y de asentir en silencio a las intervenciones-; salieron luego en hombros de entusiastas entre el delirio popular ${ }^{24}$. Pero como un símbolo de la fortuna que se cernía sobre las personas y la sociedad, Alcalá Galiano grabó en su propia intimidad la imagen última que la historia nos ha legado de don Juan Antonio: «El autor de estas líneas - escribe - no olvidará nunca el momento en que fue presentado a él en el Salón de las Cortes, ni el gesto que acompañó su tembloroso apretón de manos. Pocos días después era cadáver; una piadosa y súbita muerte le ahorró la mortificación de ver aquellos brillantes proyectos deshechos, y le ahorró también la persecución que hubiera amargado sus últimos días, bien recluyéndolo en una prisión, o forzándolo por segunda vez a errar por tierras extranjeras como compañero de otro grupo de emigrados $»^{25}$.

${ }^{23}$ SAINT-EDME, Constitution et organisation des Carbonari, ou documents exacts sour tout ce qui concerne l'existence, l' origine et le but de cette société secrète, cit. por G. DUFOUR, c., 290.

${ }^{24}$ Ante suerte tan torera, compartida por ambos oradores, no me resisto a copiar un juicio de Alcalá Galiano sobre don Agustín Argüelles, que encierra una enseñanza digna de ser meditada, y sazonada de humor: «Bien mirado todo, en la elocuencia del célebrísimo (sic) orador de Asturias, eran los defectos de aquellos que, con la edad crecen y las perfecciones al revés, de las que debían irse menoscabando y menguando hasta casi desaparecer con la fuerza de los años y la mudanza en sus situaciones. - Quien de mozo era difuso, y perdía el hilo de los raciocinios en sus arengas, en la vejez, amiga de digresiones, de rodeos y de consejos, tenía que convertirse en prolijo y desbarajustado. La pasión vehemente, que parece bien en la época de vigor corporal y mental, y excitada por justos motivos, disuena y hasta se vuelve ridícula o poco menos en un cuerpo cascado y una mente decaída, y cuando nada justifica su violencia. - Por otra parte, es Argüelles hombre de los que se mudan poco, preciándose y con razón de consecuente, y la consecuencia perfecta, aun cuando sea un mérito en lo social, como hay quienes pretendan y sustenten, no deja de ser un grandísimo obstáculo a los progresos del entendimiento. El famoso orador de 1810, el apellidado entonces divino, bien puede haber decaído del alto puesto a que arribó... La mudanza que no ha habido en don Agustín se ha efectuado en quienes oyen o leen y juzgan sus discursos...». A. AlCALÁ GaliAnO, Trabajos autobiográficos. Galería de Españoles célebres. Don Agustín Argüelles, en ID., Obras selectas, II, BAE, 84, p. 359.

${ }^{25}$ A. Alcald́ Galiano, c., 55-56.

Inquisidores contra la Inquisición

Hispania Sacra 55 (2003) 


\section{LA «COMMUNIO» QUE VIVIÓ Y SINTIÓ LLORENTE}

Es de ciencia universal que con la muerte termina todo - por lo que a este mundo se refiere-. El cadáver es la imagen nuda y final de la persona que ha concluido su existencia y que ya no está presente. Ante esa imagen, todavía los circunstantes y la historia tendrían algunas preguntas que hacer al que ya se fue; pero tienen que contentarse con hacérselas cada cual a sí mismo y satisfacerse con las conjeturas... Pero no: queda el testamento, que a veces reserva sorpresas y revela actitudes fundamentales del finado. Por ejemplo, don Fernando de Castro, habiendo vestido sotana toda su vida y dado evidencias de eclesiástico ejemplar, de honestidad sin mácula y de elevación de pensamiento, iba a escoger su tumba en el «corralillo» civil. Su testamento causó una fuerte impresión: había perdido la fe hacía años y sólo la muerte daba paso a la publicación de una intimidad dolorida.

Juan Antonio Llorente no alardeó jamás de abandono del cristianismo, ni, mucho menos, profesó ningún tipo de religión filosófica. Había en su interioridad un núcleo inviolable, que constituía su utopía inalcanzable: la pureza de los dos primeros siglos cristianos. Semejante puridad primigenia, limpia e inexpugnable, era su clave declarada, la fuente de su criticismo, la edad de oro siempre añorada que su mentalidad —como cualquier mentalidad izquierdista - necesitaba como sustento alimenticio. Su coraje - y más que coraje-, odio y empecinamiento anti-romano; su reformismo interesado, su trauma existencial, su crisis de conciencia se cohonestaban apelando a esa clave. Hoy sabemos decir, al leer sus escritos - sobre todo, los últimos, a partir del año 1820 - que el criticismo de Llorente rasgaba decisivamente su communio affectiva con la Iglesia.

Consiguientemente hay que hacer demasiados distingos para reconocer sen.tido católico en su visión de la historia de la Iglesia y en su communio effecti$v a$. Opción fundamental que corresponde a tal desgarramiento fue sin duda alguna su apuesta consciente y definitiva por el principio racionalista. A este principio racionalista adviene el jansenismo como sensibilidad adventicia. A lo largo de su vida, es bien posible que nunca hubiera probado siquiera alguna temporada de fervor sincero, de paz espiritual gozosa. Es imposible aducir una sola página inspirada en el instinctus sacerdotalis. Tavira, el mismo Grégoire, no digamos Pascal, quedan muy lejos. «El jansenismo de Llorente -escribí hace años- es mera forma accidental de su mentalidad. Salvedad importante que conviene no olvidar cuando se comprueban en la faz ideológica del eclesiástico los perfiles inconfundibles del jansenismo tardío: antijesuitismo, fobia antifrailesca, denuncia del fariseísmo eclesiástico, aversión a la Curia Romana, apelación a los orígenes del cristianismo, reformismo litúrgico, episcopalismo 
jurisdiccionalista, regalismo táctico, distinción disciplina-dogma, caridad ilustrada, amistades características, crítica mordaz» ${ }^{26}$.

Por ejemplo, el celibato fue para él una disciplina de abstinencia intolerable. No es fácil decir si alguna vez lo comprendió. Pero su discurso en contra de la praxis eclesial en este punto es completamente adverso. «La reforma introducida por Martín Lutero, propagada por Juan Calvino y otros varios del siglo XVI, ha hecho ver después con mayor claridad el error de los papas al conservar el celibato clerical. Se ve por experiencia la pureza de costumbres de los presbíteros luteranos o ministros calvinistas; por lo común son casados, con hijos, y su conducta es ejemplar, edificante y capaz de ponerse por modelo aun de los obispos católicos $\gg{ }^{27}$. Estas expresiones - y, en general, todas las que se leen a lo largo del Discurso X, Sobre el celibato clerical- delatan motivaciones íntimas. El discurso es muy frágil desde el punto de vista lógico; pero es intensamente opcional. Brota de un naturalismo rusoniano. Esa sería su lógica, presentada además con una ingenuidad que no resiste el paso de los tiempos y la experiencia elemental de quien esté al tanto de las noticias. Los problemas de la carne son dolorosos, bochornosos. Pero no son efecto de la estructura, sino de la inautenticidad con que se asume el carisma. La selección de los candidatos al sacerdocio será siempre una responsabilidad delicadísima que nunca debe descuidarse ni siquiera bajo capa de caridad. Falsa caridad sería la de aquel pastor de la Iglesia que admite a los indignos para evitarles el dolor de una prohibición necesaria.

«El ejemplo de los protestantes - continúa diciendo- produjo el efecto de ser más cautos y menos escandalosos los clérigos católicos, porque llegó a causar justo rubor el notar que aquellos ministros de la religión a quienes se achacaba mayor número de crímenes y desórdenes tuvieran vida más santa, edificante y pura que los decantados atletas de la Iglesia de Roma, titulada por ellos como la única de Jesucristo. Pero no por eso son más castos los eclesiásticos de la Iglesia Romana. El objeto que suena deseado por los papas y por el concilio tridentino deja de conseguirse hoy lo mismo que mientras había concubinas públicas. La diferencia está en el modo no en la sustancia» ${ }^{28}$. Ya se ve que Llorente no las tenía todas consigo en lo referente a la identidad cristológica de la Iglesia Romana. Un «ecumenismo» — valga la expresión anacrónica- confu-

${ }^{26}$ E. DE LA LAMA, J.A. Llorente, un ideal de burguesía. Su vida y su obra hasta el exilio en Francia (1756-1813), EUNSA, Pamplona 1991, 322.

27 J.A. LLORENTE, Discursos sobre una constitución religiosa considerada como parte de la civil nacional. Su autor, un americano. La da a luz Don Juan Antonio Llorente, Doctor en Sagrados Cánones, Imp. Stahl, 1820, 197. - Para quien no esté en autos, conviene advertir que esta obra es de Llorente ex integro: el «Autor americano», es una pseudo-autoría, a la que Llorente recurre por motivos que sería largo explicar aquí.

28 Ibidem, 198

Inquisidores contra la Inquisición

Hispania Sacra 55 (2003) 
so le llevaba a dar por buenas y equivalentes diversas confesiones históricas de signo cristiano. Pero, en todo caso, lo que parece ser el epicentro del más apasionado alegato pro domo sua es el fariseísmo de los sacerdotes católicos. Fariseísmo, por cierto, que es el recurso único y necesario de quienes son víctimas del empecinamiento de los papas. «La castidad secreta - asevera con palabras que le comprometen personalmente- no se observó, sino por poquísimos clérigos de complexión débil, enfermiza, de almas tímidas, cobardes $\mathrm{y}$, por lo común, incapaces de ciencia» ${ }^{29}$. Pero Llorente, claro está, nunca se consideró a sí mismo «incapaz de ciencia». Yo "soy tonto, pero no tanto», dijo alguna vez con fácil juego de palabras. Ahora, otro juego de igual nivel: cautos / castos: «Los clérigos son hoy más cautos, pero no más castos. Todos procuran ocultar el vicio; pero lo tienen... Muchos clérigos que temen la pérdida de su opinión en el trato con personas de otro sexo acuden al onanismo; y sea de un modo, sea de otro, viven sin la continencia que Siricio y sucesores dijeron buscar en los ministros del altar» ${ }^{30}$.

Lo cual no quiere decir que Llorente careciese de conciencia católica. La vida del hombre es una profundidad abisal y nunca es posible cortar de un tajo - sin arriesgarse a cometer injusticia - los nudos gordianos que presentan la psicología y la existencia. Debe recordarse que el pulso vital de su época era revolucionario, marcado en la mayoría de sus horas por opiniones exaltadas -muchas de ellas, de altísima eficacia - El dogma de la Infalibilidad Pontificia no estaba aún definido. No hace falta recordar que el Concilio Vaticano I iba a contribuir decisivamente a configurar la mentalidad de los católicos del siglo XX. Por el momento - en las primeras décadas del ottocento-, el influjo ilustrado había contribuido a prestigiar la razón con tal exceso que, en muchos ámbitos (no sólo Llorente era racionalista), el vigor propio del argumento de autoridad - del Magisterio de la Iglesia, por tanto- había llegado a ser considerado inadmisible como sustento de una tesis con valor científico. Se discutí.an, como si se estuviera en época constituyente, cuestiones teológicas y praxis canónicas de gran rango. Todo esto no es disculpa de la irresponsabilidad. Pero es una precisión necesaria. De hecho Llorente nunca toleró verse tratado como anticatólico o acatólico. «Sí señor - responderá a quienes acusan sus expresiones acerca del Santísimo Sacramento-, tengo esta fe, tal vez mucho más firme y mejor fundada que los censores. La distinción entre los dogmas anunciados por los Apóstoles y los definidos por los concilios generales, está ya explicada en su verdadero valor; y cuando no tuviese yo pruebas evidentes de la Presencia real en los cuatro Evangelios y en las Epístolas de S. Pablo, me bastaba y sobraba la definición del santo Concilio Tridentino, al cual como a

\footnotetext{
${ }^{29}$ Ibidem, 192

30 Ibidem, 166
} 
todos los otros ecuménicos sujeto mi razón en todos los puntos dogmáticos, aunque no lo haga siempre cuando se trata de puntos de disciplina, por las razones antes apuntadas $»^{31}$.

\section{SUCESIÓN AB INTESTATO}

En consecuencia, llegado el momento final, don Juan Antonio Llorente, «vestido de hábitos sacerdotales, estuvo depositado públicamente en esta iglesia (San Pedro el Real de Madrid) por espacio de cuarenta y ocho horas, pasadas las cuales, se cantó la misa de cuerpo presente y enseguida fue llevado al campo santo de la Puerta de Fuencarral, extramuros de esta Villa Corte, acompañándole la cruz parroquial y todo el clero de esta iglesia, en cuyo campo santo se le dio sepultura eclesiástica en un nicho que está señalado con el número $122 »^{32}$.

El entierro fue muy de primera clase: dice Mahul que se colocó sobre la tumba una moldura con la efigie del finado ${ }^{33}$. Y es bien posible, habida cuenta del costo del entierro.

Es de creer que el acta de defunción extendida en la madrileña parroquia de San Pedro recoge una información recabada de los deudos, cuando afirma: «Tenía otorgado su testamento - dice-, al parecer fecha en París, del que no se halla copia en su poder y no habiéndose presentado todavía ${ }^{34}$ en este despacho parroquial testimonio alguno de dicha disposición testamentaria no puede expresarse su contenido» ${ }^{35}$.

Estas palabras que concluyen el tenor del acta me llevaron a indagar sobre el paradero de tan interesante testamento. Para eso busqué en los «Archives de France» de donde me remitieron al «Minutier Central des Notaires» que se halla muy próximo, en 87 , Rue Vieille du Temple. Estrictamente hablando

31 Defensa de la obra intitulada «Projet d'une constitution religieuse, considérée comme faisant partie de la constitution civile d'une nation libre independante, écrit par un Américain, publié avec une preface par..., hecha en la causa formada contra la misma en el tribunal eclesiástico de esta ciudad de Barcelona por don José Antonio DE GRASSOT Y GISPERT, doctor en Sagrados Cánones y abogado de los Tribunales nacionales. Junto con la respuesta que hace a la censura de aquella obra su editor don Juan Antonio LLORENTE», (Barcelona 1821) 86-87.

32 Copia auténtica de la fe de defunción de don Juan Antonio Llorente que se halla en la Parroquia de San Pedro de Madrid, libro $8^{\circ}$ de difuntos, f. 34 v. La copia auténtica es de septiembre de 1869. Archivo de Llorente conservado por la familia González-Azpeitia Llorente.

33 Según se lee en el Montant des paiements faits par M. Ruidiaz pour compte de la succession de feu Llorente, depuis son départ de Paris, el día 25 de enero de 1825, aparece el pago de 797 francos con 25 céntimos importe debido por los funerales en Madrid. Cfr. infra, en Sucesión de M. Llorente.

34 En la copia del acta aparecen fundidas las dos palabras: presentadavia.

35 Acta de defunción, c. 
dicho «Minutier Central» no forma parte de los «Archives», sino que tiene organización independiente. Supe allí que en 1871, cuando la breve, pero violenta revolución de la «Commune» de París, fueron asaltados, entre otros, los archivos del notariado y se quemaron una multitud de protocolos, algunos de los cuales se libraron apenas de las llamas y dejaron maltrecha huella de sí; suficiente, sin embargo, como para permitir su reconstitución siquiera parcial. Para ello se creó una oficina - «Reconstitution des Actes de 1' État Civil»que trabajó intensamente. Otros se perdieron. Parecía, pues, que se trataba de «buscar una aguja en un pajar». Pero la verdad es que audaces fortuna iuvat. La audacia y el Cielo: ¿por qué no decirlo?

Lo que allí encontré fue harto satisfactorio: dos chemises de documentos, cosidos con liza como es la costumbre notarial, que contienen la Succession de M. Llorente, París, 47 rue du Faubourg de St. Honoré.

Don Juan Antonio falleció sin hacer testamento. Ni en España - parece claro- ni tampoco en París. Su salida de Francia, urgido por la policía, le impidió levantar su casa, transportar sus libros, recoger sus muebles o venderlos. Llevó consigo lo más urgente que cupo en la maleta, lo necesario para el viaje: solamente dos bultos ${ }^{36}$. Dejó en París los baúles y otros efectos que su sobrino se encargaría de hacerle llegar a través de la administración de mensajerías. En el Montant de paiements faits par M. Ruidíaz constan los gastos hechos por Llorente en las últimas horas de su estancia en París. Se lee en asientos del 14 de diciembre de 1822: un saco de viaje, un portafolios de marroquin, algunos pequeños objetos, cuatro pares de medias negras de algodón y otros dos pares de medias negras de seda, una casquette - gorra de visera - para protegerse de la crudeza de aquel invierno duro, los adelantos de dos billetes de diligencia - para sí mismo y para su secretario-. También pagó Ruidíaz unos días después un toupet - media peluca para la parte superior de la cabeza - que costó 20 francos. Llorente era muy mirado con su atuendo: todavía el 31 de enero se pagarán 222 francos al sastre por diversos trabajos adeudados. Quedaba en París, al cuidado general de sus pertenencias e intereses, su sobrino segundo, Alejandro Fernández Ruidíaz. Don Juan Antonio parece haber tenido siempre particular confianza en este pariente suyo. En 1813, al tiempo de la salida hacia el exilio de todos los miembros y colaboradores del gobierno intruso, Alejandro, se encargó de publicar la carta biográfica que Llorente había compuesto para garantizar su propia imagen.

La noticia del fallecimiento llegó a París con la rapidez posible en la época. El 13 de febrero vemos ya que Ruidíaz paga 40 francos por diversos ejempla-

\footnotetext{
36 «il a emporté avec lui deux valises, e il a laissé, à Paris, ses malles et autres effets ...», avisaba la policía que conoció todos sus movimientos hasta que salió por la frontera de Hendaya. Cfr. G. DUFOUR, c., 337, n. 44.
} 
res de la noticia sobre Llorente aparecida en «Revue Encyclopédique». No hay indicio alguno de que se hayan celebrado funerales en París. Todo el homenaje mortuorio se fue en salvas periodísticas. Los rotativos liberales intentaban hostigar al gobierno de la Restauración subrayando la inhumanidad que había supuesto expulsar a un anciano "septuagenario» - «il ne lui fut pas même permis de reposer quelques jours, à Bayonne, sa tête septuagenaire» ${ }^{37}$ - en lo más cruel del invierno y iqué invierno aquel de 1822!, se decía. A las ocho de la mañana del 29 de diciembre las aguas del Sena se habían helado bajo el puente de Neuilly y, luego, cerca ya del mediodía, también bajo el puente de Sèvres. Bajo dos de los arcos del Pont Royal también. Era insuficiente el trabajo de los obreros rompiendo el hielo para evitar los taponamientos del río: una hola de bajas temperaturas se abatía sobre Europa ${ }^{38}$. «M. Llorente - escribía Lanjuinais en la «Revue Enciclopédique»— ha sucumbido en Madrid el siete de febrero, poco tiempo después de su retorno a España, como consecuencia de las fatigas soportadas con coraje a través de una ruta larga y penosa. Los autores de semejante acto de inhospitalidad y de barbarie que habían expulsado lejos de Francia a uno de sus hijos de adopción, domiciliado en la capital desde hacía siete años, y a quien no se le podía reprochar por acto alguno contrario a los deberes de un buen ciudadano sometido a las leyes del país que habita, pueden con toda razón apuntarse el tanto de la muerte de este infortunado anciano, cuyos profundos conocimientos y el celo ilustrado por la verdadera religión le habrían permitido aún rendir importantes servicios mediante sus escritos» ${ }^{39}$.

\section{PRIMER PROCESO DE SUCESIÓN A LOS BIENES DE LLORENTE. 1823}

Muy pocos días después de llegar la noticia del fallecimiento de Llorente, Alejandro Fernández Ruidíaz presentó su requête ante $\mathrm{M}^{\mathrm{e}}$ Marchoux, notario de París, para acceder a los bienes del difunto - como pariente con mejor derecho y único heredero-. El 17 de febrero de 1823 se celebró el procès verbal d'apposition des scellés, trámite exigido para garantizar la integridad de los bie-

37 MAHUL, c., 42.

38 Cfr. G. DUFOUR, c., 344.

39 LANJUINAIS, «Recensión» a Portait politique des Papes, en Revue Encyclopédique, XVIII (avril 1823) 56. Citado también por DUFOUR, $c$., 343. - Se muestra Dufour condescendiente con el diagnóstico del Dr. Rémy, quien admite la verosimilitud de los sufrimientos del viaje como causa de la defunción de Llorente. Cfr. G. DuFOUR, $c$., 344, n. 68. Personalmente creo que el síndrome apoplético es atribuible a varias causas y en todo caso, y principalmente, a la hipertensión arterial. Que tal hipertensión haya subido a valores letales por causa de la presión psicológica padecida por Llorente -como consecuencia, no sólo del viaje, sino también del recuerdo de lo que dejaba en París y de lo que se le avecinaba en España- parece diagnóstico más verosímil que el basado en las solas inclemencias del tiempo y en la crueldad del viaje.

Inquisidores contra la Inquisición

Hispania Sacra 55 (2003) 
nes del de cuius. Quedaron precintadas las dependencias del que fuera domicilio del finado y se designó como guardiana de $\operatorname{los}_{\text {precintos }}{ }^{40}$ a la portera de la casa $\mathrm{D}^{\mathrm{e}}$ Jeanne Marie Chevalier, la cual murió muy poco tiempo después. En su lugar, en el procès verbal de 7 de abril, hubieron de señalar como guardiana de los scellés a la nueva portera del inmueble, $\mathrm{D}^{\mathrm{e}}$ Marie Françoise Dacier.

Dos meses más tarde, el 9 de junio, se hizo el inventario de los muebles, libros y enseres todos de don Juan Antonio. El 20 de junio de 1823 Fernández Ruidíaz hizo ya - como concernido por su condición de heredero- diversos pagos: entre ellos, la contribución de aquel año, el alquiler de nueve meses del piso - desde enero hasta el primero de octubre-41, todos los embalajes de los libros y los recibos presentados por los correctores de pruebas que habían trabajado en encargos de Llorente y, también, el alquiler que le cobraban por guardar los stocks de ejemplares de sus obras; pagó finalmente al librero Delaunoy los cuatro días de dedicación al inventario de los libros. A partir del mes de octubre no se pagó ningún otro alquiler por el piso del 47 rue du Faubourg de St. Honoré.

Por ministerio de $\mathrm{M}^{\mathrm{e}}$ Déa, comisario tasador de París, en ejecución de lo acordado en el procés verbal del 19 de agosto de 1823, se vendió todo el mobiliario inventariado anunciándolo con carteles y anuncios diversos. No se vendió la biblioteca Se obtuvo un producto neto - una vez pagados todos los gastos- de 306 francos con 19 céntimos. Debe advertirse que Ruidíaz aceptaba la herencia a beneficio de inventario y - de hecho, así lo hizo constar por certificado de la Greffe el 24 de septiembre del año 1827. Se estaba siguiendo, por tanto, el iter determinado para la sucesión «ab intestato» y se llevaba adelante bajo el supuesto de un único heredero. El inventario de los bienes del de cuius - se debe hacer notar igualmente- se refería tan sólo a su caudal en Francia. Aunque bien se puede colegir que los bienes en España no podían ser muchos: sólo los que se pudieron haber ocultado a los ejecutores de los decretos de confiscación.

Hubo ciertos dimes y diretes entre los parientes: puede colegirse por la reclamación de María Nieves de Vinuesa, viuda de Rubio, de algunos de los muebles inventariados, que habían sido pagados — según ella - de su propio dinero o que le habían sido regalados por el difunto. Ruidíaz protestó con firmeza refutando las pretensiones y reservándose las oportunas acciones legales, si llegara el caso. Asimismo Juan Antonio Llorente -el sobrino de de Sevilla, con quien el tío mantuvo afectuosa correspondencia - reclamaba, con cargo a

\footnotetext{
40 Scellés: cintas selladas, puestas a lo largo de las rendijas de las puertas.

${ }^{41}$ Se entiende que, tras la venta del mobiliario, y el traslado de la biblioteca a manos de Ruidíaz, el piso alquilado quedó libre.
} 
la herencia, 3.000 francos pagados por él para el entierro ${ }^{42}$, así como otros 600 francos, devengo de unos títulos de papel del Estado que estaban en manos de la señora Houillier.

Las minutas de todo el primer proceso de sucesión a los bienes de Llorente en Francia quedaron en posesión y bajo la custodia del archivo notarial de $\mathbf{M}^{\mathrm{e}}$ Marchoux, a quien sucedió en la notaría $\mathrm{M}^{\mathrm{e}}$ Corbin. Los derechos de sucesión pagados por Ruidíaz ascendieron a 97 francos con 90 céntimos.

\section{SEGUNDO PROCESO: LIQUIDACIÓN Y PARTICIÓN DE LOS BIENES DE LLORENTE.} $1826-1828$

Da la impresión de que la humilde familia de la señora Houillier procedió con lentitud, de acuerdo con su falta de preparación jurídica y con su actitud desprevenida. Pudieron comprobar que el piso de Llorente se cerraba definitivamente y que con ello desaparecía también la pensión de 50 francos mensuales que la joven madre venía recibiendo. Además, se le reclamaron seguramente- los títulos de papel del Estado que obraban en su poder. Todo esto debió de suscitar lamentos y comentarios en el seno de la familia y buscaron el camino de afirmar sus derechos.

El primer paso fue la celebración de un consejo de familia el 6 de julio de 1824 ante el Juez de Paz de Neuilly: se nombró como tutor de la pequeña Antoinette a M. Michel Barré.

Transcurrieron dos años a partir de este momento: de lo acaecido, con respecto a la herencia, durante ese lapso de tiempo no hay prueba documental. Debe suponerse que Barré interpuso sus oficios para hacer sabedor a Ruidíaz de la situación de su tutelada. Si fue así, no parece que Ruidíaz reaccionase con credulidad condescendiente. Los tiempos no llevaban consigo -ni de lejos - un reconocimiento honorífico para las madres solteras. Por fin, tuvo su inicio el segundo proceso: de liquidación y partición de los bienes de Llorente.

Era 16 de septiembre 1826, cuando se celebró el procès verbal en orden a la rectificación del inventario. Dos días antes, Ruidíaz había recibido la citación del huissier M. Couturier para que acudiese al estudio de $\mathbf{M}^{\mathrm{e}}$ Corbin. Allí se le planteó la realidad en su inequívoca crudeza. Llorente había tenido una hija reconocida legalmente: y esa criatura exigía ahora las tres cuartas partes que le correspondían por ley. Ruidíaz ya no se opuso. Se limitó a reconocer los hechos y a recuperar el dinero que había avanzado.

42 De estos 3000 francos no se volvió a hablar más en todo el proceso. Tan sólo hay constancia de los 797 francos que se pagaron por el funeral. Cfr. supra, nota 33.

Inquisidores contra la Inquisición

Hispania Sacra 55 (2003) 
Conviene advertir - aun cuando pudiera parecer obvio- que la documentación que se conserva de la sucesión a los bienes de Llorente es la de este segundo proceso: si bien en él se exhibieron y quedaron adjuntados los documentos relevantes del primer proceso, o sea, los inventarios de los muebles, ropa y libros.

Dice Mahul en su citada necrológica: «M. Llorente hubiera podido volver a su patria tras la revolución de 1820; pero ya no iba a poder recuperar las posesiones y los honores de que había sido despojado como consecuencia de los pasados acontecimientos. Y puesto que disfrutaba en París de la seguridad y de la consideración acordes con su edad resolvió quedarse aquí hasta el fin de sus días». Acertada consideración porque el eclesiástico español retornaba a su tierra natal en una circunstancia penosa no sólo para él, sino para muchos otros que compartían, en versión económica, la prolongación de los desastres de la guerra. Como escribía Javier de Burgos, era «aterrador el espectáculo de 130.000 familias arruinadas de resultas de haber comprado bienes nacionales en una u otra de aquellas épocas (1808-1813 y 1820-1823). Este temor aparecerá también exagerado, cuando se recapacite que en la primera de éstas los compradores no sólo fueron privados de los bienes que adquirieron, sino que fueron condenados a multas que consumaron la ruina de casi todos ellos» ${ }^{43}$. Tal era el caso de Llorente.

Por otra parte, el eclesiástico español se había labrado una pequeña fortuna en la capital del Sena. Vivía holgadamente en una calle de postín como la Rue $d u$ Faubourg de St Honorét4, y se había iniciado en amores: el levantamiento de Riego en Cabezas de San Juan llegaba tarde como para significar una oportunidad por entero ventajosa. El 20 de septiembre de 1820, fruto de sus relaciones con Françoise-Joséphine Houllier, había nacido Antoinette Elisa: el eclesiástico —que llevaba prácticamente vida de secularizado - reconoció a su hija identificándose a sí mismo como «hombre de Letras». El bautismo de la pequeña fue en la Parroquia de la Madeleine el día 24 de septiembre de

\footnotetext{
43 Exposición a S.M. Fernando VII desde París, 24 de enero de 1826, citada por Iris M. ZAVALA, c., $155-156$

${ }^{4} \mathrm{La}$ rue du Faubourg de St. Honoré era una de las más afamadas por el comercio de la moda: boutiques de lujo, grandes modistos, perfumerías de gran marca, galerías de arte, anticuarios. Firmas famosas de $\mathrm{S}^{\mathrm{t}}$ Honoré habían sido a lo largo del siglo XVIII los negocios de Chez Pompée,Chez Alexandrine, Chez Labille, Chez Fredier, Chez Quentin, Chez Lenoir, nombres todos ellos mágicos para los adictos a la gran moda. El Palais de l'Elysée y la rue Royale, la proximidad de la Madeleine y de la Place Concorde son elocuentes referencias para valorar lo que significaba arrendar un piso en la Rue du Faubourg de $\mathrm{S}^{t}$ Honoré, aun cuando en tiempos de Llorente el paso de la Revolución hubiese allanado mucho la gloria dieciochesca de aquella calle. Cfr. Philippe PERROT, Fashioning the Bourgeoisie. A History of clothing in the Nineteenth Century, translated by Richard Bienvenu, Princeton University Pres, Princeton/New Jersey 1994, 38.
} 
$1820^{45}$. Francia estaba curada de espantos y, de haberse divulgado el desliz, no hubiera significado para él - por lo menos en muchos ambientes - un rechazo denigrante. Pero Llorente lo mantuvo oculto ante sus deudos. A la hora de la herencia sus sobrinos - y concretamente Fernández Ruidíaz- creían ser los únicos herederos

La masa total de la fortuna que dejaba no era gran cosa, pero revela una posición de clase media, suficiente y modesta: imposibilidad de vivir de las rentas y capacidad económica para vivir en rango de pequeño burgués parisiense: capeando el temporal mediante el recurso al desarrollado mercado de bienes de segunda mano, muebles, libros, ropa ${ }^{46}$. Los ropavejeros abundaban en el barrio del Temple: allí se alquilaban o se vendían trajes usados, de color oscuro y apariencia austera o de color alegre y juvenil. Más caros o más baratos: de modo que los trajes y vestidos eran aprovechados hasta el fin, aunque estuviesen ya casi traspillados.

Los libros de Llorente - si'se atiende a los precios que les asignó el commissaire priseur - obligan a pensar en una ocupación de bibliofilia modesta: carissimi libri!, hubiera podido decir basándose en su afanosa y nada desdeñable tarea de recopilación. La biblioteca que logró reunir revela inequívocamente su afán ilustrado, su vasta curiosidad intelectual. Impossibiles libri!, porque apenas existen - si existen - en su biblioteca ediciones caras. Da toda la impresión de un buscador infatigable de libros de segunda mano, revendedor de ocasión, y buscador de nuevos títulos de obras literarias o científicas para ampliar el elenco de ejemplares ansiados. Los libros viejos eran decentemente encuadernados y, luego, si los tenía repetidos, los cajeaba o los vendía. Según parece, él mismo trabajaba también lo que podía como distribuidor de sus propias publicaciones. De hecho todavía quedaba en su casa un importante stock de algunas de ellas.

La masa económica total, una bolsa de diecisiete mil francos, no llegó a la cifra redonda de los veinte mil. No es, por lo tanto, gran cosa. A madame Houllier, la madre de Antoinette, le entregaba - según parece - para sus gastos cincuenta francos mensuales. A su secretario, Gutiérrez, lo mismo, cincuenta francos mensuales ${ }^{47}$. El alquiler del apartamento, cincuenta y cinco francos y pico

45 Cfr. Archives de Paris, Paroisse de la Madeleine, Baptêmes de 1800 à 1827, Archéveché 2700 -année 1820, $\mathrm{n}^{\circ}$ ordre 385. Dice: Nom de Famille, Lorente. Noms de baptême, Antoinette Elisa. Date du baptême 24 septembre 1820 , née le 21 septembre 1820 .

46 Sobre la importancia del mercado de moda de segunda mano cfr. Philippe PERROT, c., 41-52. - Cfr. Eugène SuE, Los misterios de París (tit. orig.: Les mystères de Paris), Bruguera, Barcelona 1968, que presenta al vivo e inmortaliza el pintoresquismo de los vendedores de segunda mano de las calles del barrio parisino de El Temple.

47 Un pasaje de E. SUE orienta sobre lo que podía ganar un artesano manual de abanicos. La acción de la novela comienza en el otoño de 1838. La Cantaora y el Puñales interpelan a Rodolfo: «Pintor de abanicos, es un oficio muy bonito -cortó la Cantaora (goualeuse). -Y qué gana con eso?,

Inquisidores contra la Inquisición

Hispania Sacra 55 (2003) 
cada mes: lo cual está bien para un apartamento en piso alto en una calle lujo$\mathrm{sa}^{48}$. A finales del XVIII la congrua de un sacerdote de medio rural era de 700 libras $^{49}$ anuales. Un racionero podía ganar el doble. Con eso vivían, ayudados también por la limosna de los fieles. Vivían pobremente, pero no como miserables. Luego, se hizo penosa la situación por las persecuciones y por la regulación del sueldo de los juramentados sobre baremo del funcionariado: es bien conocido que a muchos de ellos les acabó yendo muy mal económicamente.

Pero a lo que ahora vamos: se ha podido decir que «la estabilidad de la moneda francesa en el siglo XIX tiene algo de milagroso. El franco permaneció intacto durante el tiempo preciso en que Francia se permitió el lujo de cambiar siete veces de régimen y de sufrir tres invasiones; permaneció invariable, fiel a su definición-oro, en el mismo siglo en que las necesidades de signos moneta-

preguntó el Puñales (chourineur). -Trabajo a destajo y las buenas jornadas me producen tres francos, a veces cuatro. Pero en verano, pues los días son largos... -Y haraganea a menudo, ¿no? -Siempre que tengo dinero, y eso que no lo malgasto. En principio diez gordas por dormir en mi aposento. ¡Caramba monseñor! ¿Usted duerme a diez gordas?, clamó asombrado el Puñales mientras se llevaba la mano al sombrero. -...Me gustan las comodidades y la limpieza. -He aquí a un par de Francia! Un banquero! Un ricachón!, clamó el Puñales. Duerme a diez gordas por noche. -Además, continuó Rodolfo, cuatro perras gordas para tabaco, que suman catorce; cuatro para desayunar son dieciocho; quince para comer; una o dos para aguardiente y ya estamos en treinta y cuatro o treinta y cinco perras gordas por día. Como ves no preciso trabajar toda la semana, y el resto del tiempo me divierto.» Los misterios de París, c., 20-21. Evidentemente tanto la señora Houllier como Gutiérrez podían ganar dinero también por otros trabajos.

48 «-Señora, tengo entendido que existe en esta casa un cuarto y una alcoba por alquilar, dijo remachando la palabra señora a fin de adularla. La mujer le respondió con menos acritud: -Hay una habitación para alquilar en el cuarto, pero no se puede ver. Alfredo ha salido. -Quisiera alquilar esa habitación: el cuarto y la calle me convienen. -Quisiera saber si usted puede encargarse de su gobierno. -Con mucho gusto. Cuidare encantada de su limpieza, y por seis francos mensuales quedará servido como un príncipe. -¿Y si la habitación me conviene cuál será su precio? -Con el retrete, ciento cincuenta francos, señor. No se puede rebajar un céntimo, el casero es un avaro capaz de esquilar un huevo.» Ibidem, 144. Los pisos elevados eran más baratos que los pisos primero y principal. En la Rue du Faubourg de St Honoré, el precio del alquiler por un apartamento como el de Llorente era mucho mayor.

${ }^{49} \mathrm{La}$ libra equivalía muy cercanamente al franco. «El espíritu de sistema (propio de la época ilustrada) había tenido que hacer una primera concesión: la unidad monetaria definida anteriormente por 10 gramos de plata (vendimiario an II) se acabó definiendo por 5 gramos (thermidor an III). Representaba -eso sí- un número entero de gramos: no una cifra decimal. El franco fijado en 5 gramos a 9/10 de fino, es decir, a 4 gr. 50 alcanzaba casi a la libra turnesa, cuyo tenor en plata pura ascendía a 4 gr. 50516 (según el edicto de enero de 1726). La diferencia entre las monedas era por tanto insignificante. - Pero la libra turnesa no contenía sus 4 gr. 50516 de plata, sino a título legal. Según la tolerancia admitida en 1726, la libra podía contener tan sólo 4 gr. 419 . Y de hecho, como muchas piezas en circulación estaban usadas se aproximaban más al título de tolerancia que al título legal. Los reformadores de la Revolución se basaron sobre el principio de que el nuevo franco contenía más plata que la antigua libra... De suerte que el franco valía poco más o menos 1 libra $+1 / 80^{\circ}$ de libra: 80 francos equivalía a 81 libras. René SÉDILLOT, Le Franc. Histoire d'une monnaie des origins à nos jours, Recueil Sirey, Paris 1953, 169-170. 
rios, decuplicados por la expansión económica hubieran podido exigir el fraccionamiento del franco». El hecho es impresionante y requiere explicación por su anacronismo y su aparente falta de consecuencia con los hechos políticos que marcan una de las más graves convulsiones de tipo sociopolítico. La explicación se atribuye a un factum de tipo doctrinal: «la estabilidad de la moneda fue un dogma a lo largo del XIX. Dogma heredado, por lo demás, del siglo XVIII, que lo había puesto en práctica desde 1726. Dogma propagado por los enciclopedistas y por los economistas de la escuela clásica. Dogma adoptado por el público francés que dispensó su confianza en grado superior a cuanto se pueda pensar. El siglo XIX consideró como intangible la moneda, en torno a la cual debían moverse los precios. El franco fue tenido - al igual que el metro, o el gramo o el litro- como una unidad de medida que no era posible modificar».

Lo cual no quiere decir que los precios permaneciesen idénticos. Sino que el poder adquisitivo del franco variaba según los avatares coyunturales; pero la moneda permanecía idéntica en su definición con respecto al metal precioso: lo cual requería - eso sí- una positiva estabilidad económica, que permitiese la variación de precios sólo dentro de una banda razonable. Ya que «una moneda puede ser amenazada de dos modos. O por el déficit de la balanza de pagos, que desequilibra el mercado de divisas; o por el déficit del presupuesto, que genera aumento de la deuda pública, y que puede traer consigo un aumento de la deuda flotante o incluso un exceso de adelantos por parte de la Banca al Estado: en consecuencia, una inflación no contrabalanceada por beneficios ${ }^{50}$. Consta, sin embargo que el balance de los presupuestos desde 1816 hasta 1829 produjo un superávit acumulado hasta un valor de 47 millones de francos. Lo cual significa sin duda una progresiva recuperación del bienestar social en la época de la Restauración.

Eugène Sue, pionero del folletín social, pero indiscutible conocedor de la vida parisienne —en aquella misma época en que Llorente amasó su pequeña fortuna-, nos brinda multitud de datos que permiten una valoración muy cercana del valor adquisitivo del franco. Disculpe el lector la longitud de esta cita final cita, que me parece insustituible:

«Luego se interrumpió para detenerse delante de una tienda. — ¡Oh! Fíjese qué péndulo y qué bonitos jarrones, exclamó la modistilla-. Cuando tenga ahorrado lo que cuesten, me los compraré. Pero aún habré de esperar cinco o seis años. - ¿Hace economías con lo que gana? - No gano más que un franco y medio diario, a veces dos, pero sólo cuento con uno y medio. Hay que ser prudente - respondió Rigoletta, con aire de importancia como si se tratara de regir las finanzas de un Estado. - ¿Cómo puede vivir con un franco y medio al día? - Es muy sencillo. Con eso al día, tengo cuarenta y cinco francos al mes. De ellos tengo que descontar doce de alquiler y veintitrés para comer. - iVeintitrés

50 Ibidem, 229-230.

Inquisidores contra la Inquisición

Hispania Sacra 55 (2003) 
francos al mes para comida? -Pues claro. Confieso que para una tortolita como yo, es demasiado, pero no me privo de nada. - ¿Caramba! ¿Y qué come? - Le advierto que también cuento la comida de los pájaros. - Es cierto que viven los tres arriba. Eso ya es menos exorbitado. Pero veamos el detalle diario... Es para instruirme. - Una libra de pan, dos perras gordas; una de leche, hacen tres, dos de legumbres en invierno o de fruta y ensalada en verano, hacen cinco. Tres perras chicas de mantequilla o aceite, son quince perras chicas, si no me equivoco. Añada a esto dos o tres perras chicas de alpiste todas las semanas para mis pajarillos y verá cómo suman un total de veintidós o veintitrés francos al mes. - ¿Y no come nunca carne? - ¿Carne? i Imposible! Cuesta a doce gordas la libra. ¿Quién puede soñar con eso? Y después necesito la leña y el aceite para el invierno. Hay un plato que me gusta mucho y hago a la perfección. - Sí? ¿Cuál es? - Un buen puré de patatas rociado con un poco de leche y una pizca de sal. Es un plato de dioses. Si quiere, se lo preparo un día. - Hecho con sus manos debe estar delicioso. Pero, y el vestido, el calzado, ese lindo sombrero... - Los sombreros me los monto yo misma. Y en cuanto al vestido y al calzado, acuérdese del Temple. —Ah, ¡sí! ¡Qué felicidad de Temple! —Fíjese; este vestido que costaría unos sesenta francos lo compré por quince, después lo arreglé a mi medida. En verano se pueden comprar vestidos por cinco y seis francos, y borceguíes casi nuevos por dos y tres francos Observe, 'cualquiera diría que fueron hechos para mí - dijo Rigoletta, deteniéndose y enseñando la. punta del pie. - Su pie es encantador y le sientan muy bien. Después de esto me dirá que en el Temple también se venden zapatos de niños. - Usted es muy adulador, vecino. Pero dígame si una joven sola no puede vivir con un franco y medio diario. Y a pesar de todo, no me privo de nada. Me quedan unos francos para mis diversiones.. Tengo pájaros, jarrones con flores. Incluso llegué a poseer tres francos y medio en mi hucha» ${ }^{51}$.

No es posible ni conveniente extenderse más. Baste con lo dicho para facilitar la interpretación de esta huella de una existencia humana, que pasó ya hace casi dos siglos. Nunca sabremos cuáles fueron los últimos pensamientos de don Juan Antonio Llorente. Porque, por más que indaguemos, la profundidad del corazón humano seguirá siendo siempre un misterio.

51 Los misterios de Paris, 330-331. Para una idea bastante aproximada de la equivalencia de la libra y del franco con monedas españolas en esta época cfr. Carlos CASTÁN y Juan R. CAYÓN, Las monedas españolas desde Don Pelayo a Juan Carlos I. Años 718 a 1979, ed. por ellos mismos, Madrid 1978, pp. 1.030-1.047. Tanto la libra como el franco tienen 20 sous; el duro de plata 30 sous, lo cual quiere decir que tanto el franco como la libra equivalen a $1 / 3$ de duro o, lo que es igual, que 3 francos equivalen a dos duros. 


\section{DOCUMENTACIÓN NOTARIAL DE LA SUCESIÓN A LOS BIENES DE LLORENTE}

Minutier Central des Notaires

87, Rue Vieille du Temple-Paris

Llorente, Jean Antoine

Paris. - 47, rue du Faubourg SAINT-HONORÉ

Inventaire après décès. Meubles, vêtements, livres

9 , juin, 1823

Marroux

Cote: $\mathrm{ET} / \mathrm{XCIII} / 432$

\section{Carpeta, Cote: ET/XCIII/432}

9 Juin 1823

Inventaire après le décès de $\mathrm{M}$. Llorente

16 Septembre 1826

Procès verbal tendant à la rectification de l'inventaire ci dessus

1.A. Minuta del «acte notarié» del Inventario de los bienes del difunto Llorente, comenzado el lunes 9 de junio de 1823 y concluido el 12 del mismo mes

(N.B. Ayudará, para una buena inteligencia, precisar las definiciones de algunos términos tomados del Elsevier's Lexicon of Archive Terminology, Compiled and arranged on a systematic basis by a commitee of the international council on archives, Elsevier Publishing Company, Amsterdam, London, New York 196452: 1) « $n^{\circ} 22$. Minute est la rédaction définitive d'un écrit, préparée en vue de son expédition et destinée à être conservée par son auteur. - Pour les actes notariés (es decir los documentos redactados ante notario), on distinguait les minutes proprement dites, établies lors de

52 El Lexicon de Elsevier fue preparado por un Comité creado bajo la presidencia de M. Herman Hardenberg, archiviste général du Royaume des Pays-Bas. Trabajaron como miembros Marcel Baudot (Francia), Robert-Henri Bautier (Francia), Miguel Bordonau (España), Antonino Lombardo (Italia), Herman Meinert (Alemania), Heinrich-Otto Meisner (Alemania del Este), Peter Walne (Inglaterra). Como dice Jean Herbert, el pequeño volumen del Elsevier's Lexicon sienta autoridad en materia archivística. Por esa razón he preferido conservar en estas definiciones el idioma francés, en que está redactado el Lexicon y que conserva el texto acordado. (Cfr. Préface)

Inquisidores contra la Inquisición

Hispania Sacra 55 (2003) 
la passation de l'acte, avec des formules résumées ou simplifiées - et les minutes dites étendues, transcrites seulement au moment de l'expédition avec toutes les formules, dans des registres dits alors registre d'étendues, «liber extensarum» ou "extensoire». On désignait parfois sous le nom de «minutier» (ou registre de brèves) les registres de minutes des notaires, mais ce mot est généralement réservé à l'ensemble des minutes provenant d'un étude notariale». En castellano se llama «minuta». 2) «n 23. $L$ 'expédition est l'exemplaire mis au net d'un acte judiciaire ou notarié est dite "grosse» (...) L'expédition d'un acte administratif fait par l'autorité chargée de l'exécution est dite "ampliation»». En español se llama «original». La "ampliation» es llamada «traslado». 3) «n $n^{\circ} 65$. Un Acte écrit est un document dressé en forme soit pour servir de preuve ("acte probatoire»), soit pour manifester la volonté de l'auteur de l'acte juridique qu'il rapporte ("acte dispositif»). En castellano se habla de «documento» o de «acta». 4) «n $n^{o}$ 69. L'original est l'exemplaire original et parfait d'un document, pourvu des signes de validation destinés à lui donner pleine foi. Selon les cas, cet original peut être la minute ou la expédition première d'un document; il s'oppose à la fois à la copie et au faux». 5) «n ${ }^{\circ} 89$. Un procès verbal est un compte-rendu en forme authentique dressé par qui de droit et portant constatation et temoignage d'un fait, d'une suite de faits ou des débats d'une assemblée. En español se llama 'acta'»53.

L'an mil huit cent vingt trois le lundi neuf heures du matin,

à la requête de $\mathrm{M}$. Alexandre Fernández Ruidíaz, négociant espagnol demeurant à Paris rue Taitbout $n^{\circ} 90$, habile à se dire et porter seul et unique héritier de M. ${ }^{54}$ Jean Antoine Llorente, homme de lettres, décédé à Madrid le cinq février, son cousin issu de germain.

${ }^{53} \mathrm{Al}$ comienzo del documento se leen las anotaciones del greffier (escribano y archivero, notarial -en este caso-). Dice: Fait expédition en 12 de juin, y repite: Fait expédition: con esas palabras se deja constancia de que se han hecho sendas expediciones - una para cada una de las partes- a partir de la minuta que se conserva en la greffe o en el minutier. Esa minuta es la que manejamos. Lleva un número de protocolo: 8778 . Y seguidamente la indicación Registré. Las dos primeras planas rectas de esta pieza documental llevan la marca de tampón de MARCHOUX, N(otai)re. - Asimismo se debe hacer "notar que los tres primeros folios son de papel sellado de acuerdo con la ley: un sello de 75 céntimos y otro sello -éste de cincuenta céntimos, según ley de 1816. - 1) El sello de 75 céntimos ostenta en campo circular el emblema de la Justicia, como matrona en vestimenta clásica, que se presenta en majestad extendiendo sobre Francia -representada por un pilar señalado por una flor de lis-, su mano derecha con una rama de olivo y mostrando en su mano izquierda el speculum sobre el que se refleja un cuadrifolio -signo de la Cruz-. La Justicia protege su cabeza con el casque, que la protege de sus perseguidores. 2) El sello de 50 céntimos ostenta en campo circular la Corona de Francia y -bajo ellael Cetro, erguido, de flores de lis. De la Corona se desprenden hacia ambos lados dos tallos de lis que orlan el Cetro y que, en sendas volutas, sostienen la empuñadura de dos sables que cierran con sus filos el espacio inferior. El conjunto forma la silueta de un manto imperial. Una inscripción recorre el pas-par-tout inscrito en el sello: 50 C. en sus. Loi de 1816.

54 Actualmente, la abreviatura más autorizada de Monsieur es M. - En los textos notariales que manejamos es variable: $\mathrm{M}^{\mathrm{r}} \mathrm{o}$ M. En la transcripción, he optado por escribir dicha abreviatura siempre con el criterio actual, es decir, M.= Monsieur. Cuando el documento, prescindiendo de la abreviatura, plasma todas las letras, la transcripción también prescinde de la abreviatura y escribe por entero Monsieur. 
A la conservation des droits des parties et de tous autres qu'il appartiendra, sans que les qualités ci dessus prises puissent nuire ni préjudicier à qui que ce soit, il va être, par $\mathrm{M}^{\mathrm{e}} 55$ Louis Auguste Marchoux et son collègue, notaires à Paris, soussignés, procédé à l'inventaire fidèle et description exacte de tous les meubles, effets mobiliers, deniers comptant ${ }^{56}$, titres, papiers, livres et renseignements dépendant de la succession de $M$. Llorente, et qui se trouveront dans les lieux ci après désignés dépendant d'une maison site à Paris, rue de Faubourg $\mathrm{S}^{\mathrm{t}}$ Honoré $\mathrm{n}^{\circ} 47$ où $\mathrm{M}$. Llorente demeurait, et dont M. Soisson est propriétaire ${ }^{57}$.

La prisée des meubles et effets sujets à appréciation sera faite par M. Jean François Nicolas Dea, commissaire priseur au Département de la Seine, demeurant à Paris, rue des Jeûneurs $\mathrm{n}^{\circ} 12$, représenté par M. Martinet, aussi commissaire priseur à Paris, $\mathrm{y}$ demeurant rue de la Paix $n^{\circ} 8$, pour à présent, lequel fera la dite prisée au cours du temps, sur la représentation qui sera faite des objets par Marie Françoise Dacier, portière de la maison au rue du Faubourg $S^{t}$ Honoré $n^{\circ} 47$, gardienne actuelle des scellés dont il va être parlé, nommée aux termes d'un procès verbal de $M$. le Juge de Paris, en quatrième arrondissement de Paris, en date du sept avril mil huit cent vingt trois, en remplacement de la $\mathrm{D}^{\mathrm{e}} 58$ Jeanne Marie Chevalier, ancienne portière de la maison qui avait été nommée gardienne des scellés par le procès verbal d'apposition ci après énoncé, laquelle est depuis décédée.

Laquelle dite $\mathrm{D}^{\mathrm{e}}$ Dacier, pour ce présente, a représenté les dits objets après serment par elle fait à la manière accoutumée de n'avoir rien pris, ni détourné, ni y a qu'il ait été rien pris (página validada ${ }^{59}$ )

//

ni détourné des biens dépendant de la dite succession, et ce, au fur et à mesure que les scellés apposés sur les meubles par le Juge de Paris par Procès verbal du dix sept février dernier auront été reconnus par lui sains et entiers et levés en vertu de l'ordonnance du quatre juin présent mois.

55 Los notarios, jueces y jurisconsultos reciben habitualmente el tratamiento de Maître, que en abreviatura es $\mathrm{M}^{\mathrm{e}}$. Cuando el documento escribe por entero Maître, la transcripción también lo hace.

56 Estas dos palabras deniers comptant, son una adición auténtica, escrita en llamada al margen.

57 «Desde comienzos del siglo XIX , el notariado ha experimentado un nuevo y vivo desarrollo intelectual. Sin duda nunca en un período tan corto -durante la Revolución y el Imperio- se habían reunido tantas circunstancias capaces de provocar un gran vuelco: la reorganización judicial dominada por la influencia creciente de la Corte de casación; un derecho civil nuevo y unitario surgido de la codificación; desarrollo de la fiscalidad; reorganización y unificación del notariado mismo por la ley de ventoso del año XI.» Estas circunstancias históricas que señalan un después superador de muchos siglos de ars notaria ejercida en cierto desencuentro con la certa scientia juris, señalan el desarrollo de una nueva literatura técnica de la que son autores prestigiosos notarios; pero no sólo ellos sino también prestigiosos clercs de notaría que han asimilado en culta paridad el ars notaria y la scientia juris. La succession a los bienes de Llorente está circunstanciada justamente en esa época del nuevo notariado: veremos, por eso, el desarrollo de Procesos verbales diversos, en engranaje funcional de juges, notaires y greffiers. Cfr. Jean HILAIRE, La science des notaires. Une longue histoire, col. «Droit, éthique, société», PUF, Paris 2000, 139-150 y 295-300: «Index des ouvrages de pratique notariale».

58 Dame

$59 \mathrm{Al}$ final de la página, la validación lleva tres paraphes: el de Ruidíaz, el de Martinet y el de Cruby.

Inquisidores contra la Inquisición

Hispania Sacra 55 (2003) 
Et a M. Ruidíaz et le commissaire présent signé avec les notaires, la dite $\mathrm{D}^{\mathrm{e}}$ Dacier gardienne des scellés ayant déclaré ne savoir écrire ni signer, de ce interpellée, faisant de loi le tout après lecture.

(Siguen las firmas y rúbricas de) A. F. Ruidiaz, Martinet, Riant, Marchoux ${ }^{60}$

1.B. Inventario de los bienes muebles que hay en la casa. No, de los libros.

Suit la prisée ${ }^{61}$

Dans une chambre au second étage éclairée sur la rue par deux croisées $^{62}$, sur la porte d'entrée de laquelle étaient apposés les scellés ${ }^{63}$

Cinq fauteuils en bois de merisier ${ }^{64}$ et foncés de paille 65 ; un autre fauteuil en bois

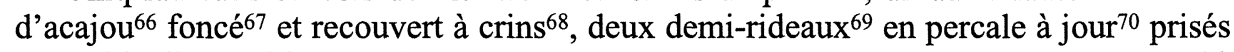
ensemble dix neuf francs, ci

Une pelle ${ }^{71}$ et une paire de pincettes ${ }^{72}$, deux petits vases ${ }^{73}$ de porcelaine avec fleurs artificielles sous leur cilindre $\left(\mathrm{sic}^{74}\right)$ en verre ${ }^{75}$ prisés quatre francs, ci

$60 \mathrm{Al}$ margen se lee: Rayé neuf mots comme nuls. De ordinario no se indicarán las palabras tachadas -a no ser que esas tachaduras tengan alguna relevancia-. - Siguen, también al margen, los paraphes -es decir, las rúbricas- de Ruidíaz, Martinet (priseur citado en el documento), Riant (notario, cfr. Almanach Royal 1828, p.787, donde aparece en la lista de los notarios de París), Marchoux (notario) y Cruvy (presente en el inventaire como receptor de las tasas del Enregistrement). Términos: Parapher. Document dûment paraphé. - Cada advertencia o llamada al margen tiene que estar paraphée. Sin necesidad de firma, las rúbricas son perfectamente identificables en las advertencias, llamadas o correcciones al margen. Sólamente al final del documento de que se trate -acta, proceso verbal, inventario etc. - van las firmas y rúbricas de todos los que intervienen.

61 Tasación.

62 Con luz de la calle a través de dos ventanas

63 Sobre la puerta de entrada donde se habían puesto los sellos

64 Cerezo silvestre muy apreciado en ebanistería.

65 Con fondo de paja. Con asiento de paja. (De foncer: munir d'un fond). Cfr. v.g. el Fauteil paillé de fines del XVIII o comienzos del XIX, del Museo de Conflans. Albertville, en Nicole DE REYNIÉS, Conservateur de l' Inventaire Général et des Fouilles archéologiques, Inventaire Général des monuments et des richeses artistiques de la France. Le mobilier domestique, Ministère de la Culture et de la Communication, Imprimerie Nationale, Paris 1987, 87, fig.193.
66 Caoba.
67 Con asiento.
68 Recubierto de crines.
69 Medias cortinas
70 Percal, tela fina de algodón con calados.
71 Paleta para remover el fuego
72 Tenazas para arreglar la lumbre
73 Floreros
74 Por cylindre.
75 Sin duda, cilindro de vidrio protector a modo de fanal. 
Une petite pendule ${ }^{76}$ en cuivre avec sonnerie ${ }^{77}$ du nom Epenoy, horlogerie à J. Denis sous sa cage de verre bombé ${ }^{78}$ prisée quarante francs, ci

Un secrétaire en bois d'acajou à cinq tiroirs ${ }^{79}$ et deux tablettes ${ }^{80}$ sur les côtés prisé quarante francs, ci

Six casiers ${ }^{81}$ à bibliothèque en bois peint ${ }^{82}$ prisés vingt cinq francs, ci .................... 25

Une glace d'un seul morceau ${ }^{83}$ dans son cadre de bois doré 84 et sur son parquet en bois peint en gris ${ }^{85}$ portant environ trois pieds de haut ${ }^{86}$ sur (...) ou deux pieds six pou$\operatorname{ces}^{87}$ de large prisée quatre vingt francs, ci

Dans une autre chambre servant de chambre à coucher ${ }^{89}$ ayant son entrée par la pièce précédente et éclairée ${ }^{90}$ par une croisée sur la cour ${ }^{91}$

Une couchette à deux dossiers ${ }^{92}$ en bois de hêtre ${ }^{93}$ peinte en bleue (sic), roulet-

\footnotetext{
76 Reloj de chimenea

77 Juego de campanas

78 Caja de vidrio combado

79 Cajones

80 Pequeñas mesas

81 Estanterías

82 Madera pintada

83 Luna de una sola pieza

84 Marco
}

85 Parquet de madera pintado en gris. Parquet-según Nicole DE REYNIÈS, $c$., 11-se define: partie de bois doublant le revers d'une glace. Es decir: el reverso del espejo, la madera que lo protege y contiene. - El inventaire da seguidamente la medida del parquet.

863 pies de altura. En Francia, a principios del XIX, equivalía cada pie a $32,5 \mathrm{~cm}$.

872 pies y 6 pulgadas de anchura. Cada pulgada equivale a $27,07 \mathrm{~mm}$.

$88 \mathrm{Al}$ comienzo de la plana están los dos timbres: el de $75 \mathrm{cms}$. y el de 50 céntimos de la ley de 1816. También está en la esquina derecha el membrete que dice: «Marchoux. $\mathrm{N}^{\mathrm{re}}$ »

89 Dormitorio

90 Abierta al patio a través de una ventana

91 Las palabras en negrita no están subrayadas de ningún modo en el documento.

92 Cama de dos respaldos. No se trata de un lit sino de una couchette. Tanto el lit como la couchette pueden ser à deux dossiers. De lit à deux dossiers hay un soberbio ejemplo en el cuadro de Jacques-Louis DAVID, Madame Récamier, de 1800, Musée du Louvre, Paris. Cfr. a tal respecto Jean STAROVINSKI ET ALII, Revolution in Fashion. European Clothing, 1715-1815, Abbeville Press/Publishers New York 1990, 115, donde se reproduce el cuadro en óptima fotografia. - Cfr. et. Nicole DE REYNIĖs, c., 192 ss, 225 ss. El Inventaire de $\mathbf{M}^{\mathrm{e}}$ Marchoux usa el término de couchette a deux dossiers; los especialistas dicen más frecuentemente: lit de repos à deux chevets. Lits de travers à deux chevets. Hay también lits à trois dossiers. Cfr. Nicole DE REYNIĖS, Ibidem. - Otra bibliografia clásica sobre mobiliario francés, cfr. Jean DE VIGUERIE, Histoire et Dictionnaire du temps des Lumières, col. «Bouquins», Robert Laffont, Paris 1995, 1624-1625. Aquí debo hacer constar mi agradecimiento al Prof. Dr. Joaquín Lorda, de la Escuela Superior de Arquitectura de la Universidad de Navarra, por sus valiosas orientaciones bibliográficas a este respecto.

93 Haya

Inquisidores contra la Inquisición

Hispania Sacra 55 (2003) 
tes $^{94}$ communes, fond sanglé ${ }^{95}$, un sommier et deux matelas ${ }^{96}$ recouvert en toile à carreau $^{97}$, une couverture ${ }^{98}$ en laine, un traversin ${ }^{99}$ et deux oreillers ${ }^{100}$ remplis de plumes et couverts en coutil ${ }^{101}$ rayé ${ }^{102}$ prisés ensemble quatre vingt quinze francs, ci .... 95

Trois chaises ${ }^{103}$ et un fauteuil foncés de paille ${ }^{104}$, une table de nuit en bois de noyer ${ }^{105}$, deux lampes ${ }^{106}$ prisés ensemble dix francs, ci

Une augustine ${ }^{107}$, une pelle à braise ${ }^{108}$, une poêle ${ }^{109}$ à frire, un souflet (sic $\left.{ }^{110}\right)$, un flambeau en cuivre ${ }^{111}$ et un boujoir ( sic $^{112}$ ) en fer-blanc ${ }^{113}$ prisés ensemble deux francs, ci ...... 2

Un lavabo en bois d'acajou avec son pot $^{114}$ et sa cuvette ${ }^{115}$ en fer porcelaine ${ }^{116}$ en mauvais état prisés cinq francs, $\mathrm{ci}$ 5

Une gravure sous verre ${ }^{117}$ avec son cadre de bois doré118 prisée un franc cinquante centimes, ci $1 ' 50$

Quatre paires de souliers ${ }^{11}$, dix gilets ${ }^{120}$ et vestes ${ }^{121}$, une culotte ${ }^{122}$ en draps étoffe et futaine ${ }^{123}$ prisés trois francs cinquante centimes, ci 3'50

94 Pequeñas ruedas, implantadas en sencillos mecanismos de doble eje, capaces de deslizarse sobre el suelo en todas las direcciones y que están sujetas' a las patas o a los bajos de un mueble para trasladarlo con suma facilidad. Fauteuil à roulettes, table à roulettes.

95 Fondo del lecho de cinchas entrecruzadas, hechas de cuero o de lona muy fuerte.

96 Colchón

97 Tela almohadillada.

98 Manta

99 Almohada

100 Almohadones

101 Dril

102 De rayas

103 Sillas

104 Con asientos de paja

105 Nogal

106 Lámparas

107 Chaufferette dans laquelle une lampe à l' esprit-de-vin sert de foyer-dice el Grand Larousse-. Una pequeña estufa de alcohol.

108 Badila

109 Sartén

110 Por soufflet, fuelle

111 Antorcha de cobre

112 Por bougeoir, palmatoria, candelero

113 Hojalata

114 Jarra

115 Palangana

116 Hierro-porcelana

117 Grabado cubierto por un cristal

118 Marco de madera dorada

119 Zapatos

120 Diez chalecos

121 Casaca

122 Calzón

123 Telas de paño y de fustán 
Dans un placard d'armoire ' $^{124}$

Une soutanne ( $\left(\mathrm{C}^{125}\right)$ et un capuchon en serge ${ }^{126}$, un gilet et une petite soutanne (sic) en soie ${ }^{127}$, un bonnet carré128 en draps ${ }^{129}$, un chapeau a trois cornes prisés ensemble quinze francs, ci 15

Une veste en soie noire ${ }^{130}$ et une redingotte $\left(\operatorname{sic}^{131}\right)$ en bouracan ${ }^{132}$ prisés ensemble neuf francs, ci

Trois surplis ${ }^{133}$ et une aube ${ }^{134}$, une amec $\left(\operatorname{sic}^{135}\right)$ en toile et grosse mousseline et une autre amec (sic) prisés ensemble dix huit francs, ci 18

Onze paires de chaussons en coton ${ }^{136}$, quatre chemises en toile prisés vingt cinq francs, ci ..... 25

Quatre serviettes ${ }^{137}$ dont trois a liteaux ${ }^{138}$ bleues, et une barrée ${ }^{139}$, deux caleçons ${ }^{140}$ en toile, ${ }^{141}$ deux autres serviettes et un torchon ${ }^{142}$ prisés ensemble neuf francs, ci ....... 9

124 En un armario empotrado. - Las palabras en negrita no van subrayadas ni resaltadas de ningún modo en el documento.

125 Por soutane

126 Un capuchón de sarga

127 Una pequeña sotana en seda. Se trata probablemente de un cuerpo de sotana acomodado al busto y con faldón hasta poco más abajo de la cintura o, tal vez, de las caderas -según se recoja en la cintura por dentro de la culotte o no-. La culotte puede ser negra o de color gris: tal era el traje de clérigo a la francesa. La prenda es sin duda muy elegante y sustituye al gilet, que el traje común de la burguesía exigía bajo la veste. Sobre esta petite soutane se ponía la veste -como un sur tout también de seda- que aparece en el siguiente asiento.

128 Bonete cuadrado. El nombre bonnet puede referirse a diversos objetos: desde un gorro de dormir hasta un birrete de doctor. Pero el hecho de que en este armario de pared se hallen reunidas diversas prendas clericales persuade de que se trata más bien de un bonete eclesiástico. Tal vez, de un bonete de cuatro puntas, al estilo español.

${ }^{129}$ De tela. Draps es término plural. Se trataría de un plural genérico e inconcreto que indica la hechura con diversos elementos de tela.

130 Esta veste, casaca o levita de seda negra, seguramente hacía juego con la aludida petite soutane.

131 Por redingote.

132 Bouracan -en principio, tal como se entiende en Valenciennes- es un tejido grueso de camelote, paño hecho de pelo de cabra mezclado con lana, y también - a veces, para suavizar-con seda en su urdimbre. Se entiende que se trata en todo caso de un tejido tosco.

133 Sobrepelliz

134 Alba

135 Por amict. Amito. El sustantivo amict es masculino, aunque en el documento se le dé concordancia de femenino.

136 Escarpines de algodón.

137 Toallas

138 Tres de las cuales, con listas azules

139 Con barras

140 Calzoncillos

${ }^{141}$ En el manuscrito siguen aquí aparentemente subrayadas las palabras:Cinq gilets blancs; debe, sin embargo, deducirse que se trata de un simple rayado de anulación: una diligencia notarial -al fin de esta parte del inventario - advierte de la tachadura de 8 palabras. No cabe, por tanto, duda alguna -tras hacer el recuento-.

142 Rodilla de cocina.

Inquisidores contra la Inquisición

Hispania Sacra 55 (2003) 
Une ceinture ${ }^{143}$ en soie, sept chemises en toile dont cinq élimées ${ }^{144}$ et deux neuves, trois caleçons, quatre taies ${ }^{145}$ d'oreiller et traversin en toile et calicot ${ }^{146}$, quatre faux cols $^{147}$, deux cravattes $\left(\right.$ sic $\left.^{148}\right)$, prisés ensemble trente six francs, ci ................................. 36

Une paire de draps ${ }^{149}$ en toile élimée ${ }^{150}$, un couvre-pied en toile de coton garni de mousselines ${ }^{151}$ prisés ensemble seize francs, ci ................................................................... 16

Un petit miroir ${ }^{152}$ rond, un couteau et une fourchette en ivoire ${ }^{153}$ prisés deux francs, ci

Quatre casiers en bois blanc peint en gris154 prisés dix francs, ci

(suma total hasta aqui) ................................................................................ 465 francs ${ }^{155}$ (página validada)

//

(suma total hasta aqui) 465 francs

Dans un autre placard d'armoire ${ }^{156}$

Dix bouteilles, et demi bouteilles ${ }^{157}$ en gros verre, et une remplie de Rhum, prisées trois francs, ci 3

Dans une autre pièce ensuite de la précédente éclairée par une croisée sur la cour ${ }^{158}$

Une fontaine carrée en pierre avec deux robinets en étain ${ }^{159}$ prisés quatre francs, ci .... 4

Un secrétaire en bois de noyer à abattant ${ }^{160}$ prisé seize francs, ci .............................. 16

Un lit de sangle ${ }^{161}$, une paillasse ${ }^{162}$, un matelas couvert en toile à carreau ${ }^{163}$, un traversin couvert en coutil rayé ${ }^{164}$, deux vieilles couvertures et un couvre-pied en laine prisés ensemble trente huit francs, ci 38

\footnotetext{
143 Faja de seda

144 Gastadas

145 Fundas de almohadón

146 Calicó. Tela delgada de algodón.

147 Cuellos postizos

148 Por cravates. Corbatas

149 Sábanas

150 En tela gastada

151 Guarnecido de muselinas

152 Espejo

153 Un cuchillo y un tenedor de marfil

154 Estanterías en madera blanca pintada de gris

155 Hay un error en la suma de este folio. Deberían ser 463 francos, salvo error u omisión.

156 Las palabras en negrita no van resaltadas de modo alguno en el documento.

157 Botellas y medias botellas

158 Pieza junto a la precedente con luz del patio a través de una ventana. - La negrita no responde a ningún resalte en el documento original.

159 Fuente cuadrada en piedra con dos grifos de estaño

160 Persiana abatible sobre la mesa del secrétaire.

161 Lit de sangle: catre, catre de tijera.

162 Jergón

163 Almohadillado

164 Almohada cubierta por su funda de dril a rayas.
} 
Trois vieilles chaises, un casier, douze bouteilles en verre vuides ${ }^{165}$, et un lot de bouttlles $\left(\right.$ sic $\left.^{166}\right)$ en [épais ${ }^{167}$ ], prisés ensemble sept francs, ci

Dans une petite chambre en mansarde 168 au cinquième étage sur la porte de laquelle étaient apposés les scellés de Me. le juge de Paris ${ }^{169}$

Deux malles ${ }^{170}$ et trois caisses ${ }^{171}$ en bois blanc, prisés sept francs, ci 7

Il a été vaqué à tout ce que dessus ${ }^{172}$, depuis la dite heure de neuf heures du matin, tant à la rédaction de l'intitulé du présent inventaire qu'à tout ce qui précède ${ }^{173}$, jusqu'à celle de trois de relevée ${ }^{174}$.

Ce fait, les objets inventoriés -et ceux restans à l' être ${ }^{175}$-, ont continué de rester ${ }^{176}$ en la garde et possession de la dite Dame Dazier; et ce, après serment de nouveau prêté177 par elle de n'avoir rien pris ni détourné après que les scellés ont été reaposés $\left(\operatorname{sic}^{178}\right)$ par $\mathrm{M}^{\mathrm{e}}$ le Juge de Paris, et la vaccation $\left(\operatorname{sic}^{179}\right)$ pour la continuation du présent inventaire a été remise et indiquée à demain Mardi dix du courant neuf heures du matin.

Et ont M. Ruidiaz et Me. le Commissaire priseur signé avec les notaires, la dite gardienne des scellés ayant de nouveau déclaré ne savoir écrire ni signer de ce interpellée. Le tout après lecture

(suma total) $\underline{540 \text { francs }}$

(Firmas y rúbricas de:) Ruidíaz, Martinet, Riant, Marchoux ${ }^{180}$

165 Vacías. Cfr. voz vuidé y vuider en M. DIDEROT \& M. D’ ALEMBERT, Encyclopédie ou Dictionnaire raisonné des Sciences, des Arts et de Métiers, par une Société de Gens de Lettres, mis en ordre et publié par --- \& ---, XVII, Chez Samuel Faulche \& Compagnie Libraires \& Imprimeurs, Neufchastel, M DCC LXV, Nueva edición facsímil de la primera edición, Friedrich Frommann Verlag (Günter Holzboog), Stuttgart-Bad Cannstatt 1967. Cito esta edición ya que la palabra vuidé, hoy desusada, no se encuentra en recientes diccionarios.

166 Por bouteilles. O, tal vez, la aproximación a la palabra inglesa bottles podría indicar un lote de botellas inglesas de importación.

${ }^{167}$ En épais: es decir, con sustancia, llenas. Cfr. et. voces épais y preposición en, en la ya citada M. DIDEROT \& M. D’ ALEMBERT, Encyclopédie, v.

168 Buhardilla

169 Las palabras en negrita no van resaltadas en el documento original.

170 Baúles, maletas

171 Cofres

$172 \mathrm{Ha}$ sido dedicado a todo esto que anteriormente.

173 Tanto a lo que se refiere en el título del presente inventario como a todo lo que precede.

${ }^{174} \mathrm{La}$ tarde. Desde las 9 de la mañana hasta las tres de la tarde, por tanto.

$175 \mathrm{Y}$ los que quedan por serlo.

176 Han continuado quedando

$177 \mathrm{Y}$ esto, tras juramento por ella prestado de...

178 Por reposés.

179 Por vacation. Tiempo que emplea el funcionario en despachar un negocio. Aquí significa que el tiempo para dedicarse a la continuación del presente inventario ha sido dejado y señalado para mañana

$180 \mathrm{Al}$ margen: Rayé huit mots comme nuls. Siguen a esta advertencia, también al margen, los paraphes de validación de todos los presentes que saben escribir.

Inquisidores contra la Inquisición

Hispania Sacra 55 (2003) 


\section{C. Inventario y tasación de los libros de la Biblioteca}

(Suma total hasta aqui)

540 francs

Et le dit jour mardi dix juin mil huit cent vingt trois, en conséquence de l'indication prise par la vacation qui précède, il va être, par le dit $\mathrm{M}^{\mathrm{e}}$ Marchoux et son collègue notaire ${ }^{181}$, soussignés, procédé à la continuation du présent inventaire et mêmes requête et présence que des autres parts.

Suivent les livres, dont la prisée sera faite par le dit sieur Martinet, commissaire priseur remplaçant le dit M. Dea, de l'avis de M. Simon César Delaunoy, libraire patenté pour la présente année sous le 260 de marc d'or ${ }^{182}$ à Paris, au Palais Royal, Galerie de Bois $n^{\circ} 243$, à ce présent, expert choisi par M. Ruidíaz, et qui a prêté serment entre les mains des notaires soussignés de faire cette prisée en son âme et conscience.

Dans la chambre éclairée sur la rue par deux croisées a dessus désignée, sur la porte d'entrée de laquelle étaient apposés les scellés ${ }^{183}$.

1.- Dictionnaire classique de SABATIER ${ }^{184}$ en trente six volumes in $8^{\circ}\left(\right.$ sic $\left.^{185}\right)$, reliés, prisés quarante cinq francs, ci

2.- Vingt volumes in $8^{\circ}$, dont Revue Encyclopédique, reliés, prisés dix huit francs, ci

3.- Huit volumes dont Siècle littéraire ${ }^{186}$, reliés, prisés dix francs, ci 18 10

${ }^{181} \mathrm{El}$ colega notario que acompaña a $\mathrm{M}^{\mathrm{e}}$ Marchoux es $\mathrm{M}^{\mathrm{e}}$ Riant, cuya firma hemos visto ya en el auto de comparecencia.

182 La letra apretada y la abreviación $m$ con un signo + en superíndice permiten conjeturar la resolución aceptada en el texto.

${ }^{183}$ Las palabras en negrita no van resaltadas en el original.

184 François SABBATHIER, Dictionnaire pour l'intelligence des auteurs classiques, grecs et latins, tant sacrés que profanes, contenant la géographie, l'histoire, la fable et les antiquités; dédié à M. le Duc de Choiseul. Châlons-sur-Marne et Paris, Delalain, Barrois aîné, 1786-1815, 37 vols. in- $8^{\circ}$., dont un de planches. - Cfr. J.M. QUÉRARD, La France Littéraire ou Dictionnaire bibliographique des savants, historiens et gens de lettres de la France, ainsi que des littérateurs étrangers qui ont écrit en français, plus particulièrement pendant les XVIII et XIX siècles, Maisonneuve \& Larose, éditeurs, Paris 1964.

185 De ordinario el numeral fraccionario va en letra. Pero con excepciones, como en este caso.

186 Pierre Louis D'AQUIN DE CHÂTEAU-LYON, Siècle Littéraire de Louis XV: ou Lettres sur les hommes célèbres, AMS Press, New York 1978, 288 pp. Reprint of the 1754 ed. published in Amsterdam. - Parece claro que los ocho vols. encuadernados bajo ese título recogen también otras obras afines de Château-Lyon, como por ejemplo volúmenes sueltos del Almanach Littéraire ou Etrennes d'Apollon que se fue publicando en París de 1777 a 1806. Ciertamente, tras la muerte de ChâteauLyon en 1796, lo prosiguió C.-J.-B. Lucas-Rochemont et Millevoye. Cfr. QUÉRARD, c. - Cfr. et. M. Prevost, Aquin de Châteaulion, Antoine d', en M. BARROUX, M. PREVOST et alii, Dictionnaire de Biographie Française, I. -Existe una revista titulada Siècle Littéraire, bimensual, que se comenzó a publicar en París de 1875, su director Henri Malin, de la cual se conservan los números correspondientes a siete meses en la Bibliothèque Nationale de France. 
4.- Seize volumes in quinto, reliés, partie séparée de l'Encyclopédie méthodique ${ }^{187}$, prisés soixante francs, ci

5.- Neuf volumes in quarto dont Dictionnaire Anglais de JONSON ${ }^{188}$ et deux in octavo dont Dictionnaire de BOYER ${ }^{189}$, prisés ensemble quinze francs

${ }^{187}$ El título Encyclopédie méthodique es compartido por obras magnas de diversas materias como historia natural, matemáticas y física, música, marina, zoología y mamíferos en general, moluscos y pólipos, economía y política, geografia antigua y moderna, filosofía antigua y moderna, etc. Pienso no obstante que la referencia paradigmática -por los tiempos de Llorente- seguía siendo la de DIDEROT \& D' ALEMBERT, Encyclopédie méthodique ou par ordre de matières, par une société de gens de Lettres, de savants et d'artistes: précédée d' un vocabulaire universel, servant de table pour tout l'ouvrage, orné des portraits de --- \& ---, premiers éditeurs de l' Encyclopédie: publiée en deux formats: in $-4^{\circ}$ à trois colonnes ... et in $8^{\circ}$ à deux colonnes, Imprimerie Stoupe, 1782, 8 vols. - La edición de 1782 es anterior en dos años antes a la muerte de Diderot. - También Jacques André NAIGEON, colaborador de Diderot, publicó una Encyclopédie méthodique: philosophie, ancienne et moderne, Panckoucke imprimeur et libraire, Paris 1791, 3 vols. El título por tanto se había prestigiado o puesto de moda. - Asimismo, el famoso Jean Baptiste Pierre Antoine de Monet de LAMARCK, Encyclopédie méthodique, Panckoucke imprimeur et libraire, Paris 1783-1808, 8 vols. - No se puede en modo alguno olvidar el empuje económico, transformador y progresivo de la burguesía, que se manifiesta en el boom de los diccionarios. El gran magnate de la imprenta es Charles-Joseph Panckoucke que amasa una fortuna y un verdadero imperio editorial. Su Encyclopédie Méthodique alcanza las cumbres editoriales con 126 vols. In- $4^{\circ}$ de texte +40 vols. de láminas y de mapas, Paris 1791-1832. El número de tomos se amplía en sucesivas ediciones. (El formato, así como la distribución de las planchas, explica la diversidad de datos sobre el número de tomos, según se trate de una u otra edición) Ya se entiende que para tamaña empresa se había de contar con muchos colaboradores. Más de 130 se comprueba que trabajaron en la composición de los miles de artículos que la integran. Cfr. Suzanne TUCOOCHALA, Charles-Joseph Panckoucke \& la Librairie Française. 1736-1798, éd. Marrimpouey Jeune/Lib. Jean Touzot, Pau/Paris 1977, 559 pp. - Cfr. et. el interesante artículo de Pierre RÉTAT, Dictionnaire, en Michel DELON dir., Dictionnaire européen des Lumières, PUF, Paris 1997, 333-335.

188 Samuel JoHNSON, A Dictionary of the English Language, in which the words are deduced from their originals and illustrated in their different significations by examples from the best Writers, 1755. - Samuel Johnson (nacido en Lichfield, Stafford-Shire, en 1709, fallecido en 1784 y enterrado en Westminster Abbey), es uno de los más brillantes escritores ingleses de su tiempo. Su dictionary es el primero de su lengua y de él se han hecho multitud de ediciones hasta bien entrado el siglo XIX. Significa de por sí, una auténtica referencia en la historia léxicográfica inglesa y no sólo inglesa sino universal: a juicio de Pierre Larousse, el diccionario de Johnson es considerado como el mejor que existe, sobre cualquier otro de cualquier lengua. «L'historien Robertson assure qu'il a lu le dictionnaire de Johnson d'un bout à l'autre. Souvent le lexicographe anglais allie l'humour à la gravitè de ses définitions, et on ne peut s'empêcher de reconnaître qu'il le fait avec une rare rare bonheur». Pierre LAROUSSE, Préface a Grand Dictionnaire Universel du XIX $X^{e}$. Siècle, français, historique, géographique, biographique, mythologique, bibliographique, littéraire, artistique, scientifique, etc. bajo la responsabilidad editorial de de Pierre LAROUSSE, I, París 1865, p. LII-LIV. Johnson trabajó incansablemente ayudado de seis amanuenses encargados de copiar las muchísimas citas -su primera edición exhibía más de 116.000 de autores reconocidos, que suponían el resultado de un previo acopio de una cantidad doblemente superior-. En aquellos tiempos cuando el instrumento principal era la memoria viva, verdadero archivo de erudición, el trabajo de Johnson debe ser comprendido como una verdadera master-piece. La primera edición fue un tomo in-folio. Luego el dictionary experimentó el crecimiento natural y las ediciones aparecen en formatos más grandes. -Vale la pena citar -por su presti-

Inquisidores contra la Inquisición

Hispania Sacra 55 (2003) 
6.- Douze volumes in folio dont Dictionnaire de MORER ${ }^{190}$, prisés quinze francs, ci

7.- Quinze volumes in folio dont la Sainte Bible ${ }^{191}$, prisés dix huit francs, ci ........ 18

8.- Huit volumes in folio dont OVIDE ${ }^{192}$ prisés douze francs, ci ................................ 12

9.- Neuf volumes in folio et in quarto dont STRABO ${ }^{193}$, prisés quinze francs, ci ... 15

gio-, aunque sea posterior a la muerte de Llorente, la edición «verbatim from the author's last folio edition» publicada por H.G. Bohn, London 1828. - Cfr. Donald GREENE ed., Samuel Johnson. A Critical Edition of the Major Works, col. «The Oxford Authors», Oxford University Press, Oxford/New York 1984, pp. XX-XXI, 307-334, y 810-811, nota.

${ }^{189}$ Abel BOYER (muerto en 1729) es un pionero de la historia lexicográfica francesa. Su diccionario multiplicó sus ediciones hasta bien entrado el siglo XIX y sigue siendo un hito impreterible. Contemporánea a los días de Llorente (lo cual no quiere decir que el eclesiástico español poseyera precisamente ésta)

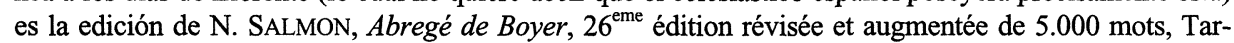
dieu-Denesle, 2 vols. Paris 1821. - Anteriormente, Panckoocke había editado el Dictionnaire de BOYER, anglais et français, in $4^{\circ}$ et in $8^{\circ}$, nouvelle édition, en 1768. Cfr. TUCOO-CHALA, $c$., 536.

190 Abbé Louis MORĖRI (25.III.1643 y +16.VII.1680), Le Grand Dictionnaire Historique, ou la mélange curieux de l'histoire sacrée et profane, $\mathrm{IX}^{\mathrm{e}}$ éd. Amsterdam 1702, 4 tom. 2 vols. in-fol.- No obstante la primera edición, única que salió en vida del autor, es de 1674, ed. Jean Gyrin, Lyon, que apareció en un único vol. in-fol. - Ya la edición de 1759 -la XXe . y última- constaba de 10 vols. in-fol + 3 de supplément. Se vendía por 90 ó 100 francos. Se ve claramente el negocio librero que proporcionaban los diccionarios.- Cfr. QUÉRARD, $c$.

191 No es fácil saber cuál era el ejemplar de la Santa Biblia a que el presente item se refiere. La hispana Biblia Políglota, aun comprada de viejo, era sin duda mucho más cara que 18 francos. Quince tomos parece un número excesivo para una sola Biblia. Tal vez se trate de ejemplares repetidos -dedicados a la venta o al intercambio- de la Sainte Bible en francés. -Una de las más famosas, si no la más es la Sainte Bible, édition de la Vulgate dans la version de Isaac Louis LE MAISTRE DE SACY, imp. a deux couleurs, 1819, 883 pp., $23 \mathrm{~cm}$. Le Maistre era jansenista, sobrino de A. Arnauld y muy bien conocido, habida cuenta de su dilatado influjo. - Por otro lado, la Constitución Dominici gregis custodiae de 24 de marzo de 1564 publicaba las «Reglas tridentinas» para la prohibición de libros y, entre ellas, limitaba la publicación de la Biblia en lenguas vernáculas, a no ser que fuesen anotadas críticamente por autores probados, doctos en historia y en teología. Ello dificultaba el acceso a las traducciones bíblicas. El surgimiento del movimiento jansenista -caracterizado por su atrevimiento polémico- tuvo 'su más afamado traductor en Le Maistre de Sacy. Plumas de ese corte no estaban dispuestas a detenerse ante los «escrúpulos tridentinos». No sería, pues, extraño que la Sainte Bible de este item fuese la de Le Maistre -versión, por lo demás, menos objetable que la llamada de Calvino o que otras versiones que pudieron correr para la lectura de los hugonotes-. Cfr. H. Denzinger/ P. Hünermann, Enchiridion symbolorum, Herder, Barcelona 1999, nn. 1851-1861 con su introducción.

192 Prescindo de comentar aquellas obras literarias universalmente conocidas en la historia de la cultura y que habitualmente han tenido ediciones. Nos basta conocer el interés de Llorente por leer y difundir los autores del clasicismo literario.

193 ESTRABÓN (nacido en Amasia a mediados del siglo I a.C. y fallecido hacia el año 20 p.C.) Es el más célebre de los geógrafos de la Antigüedad Clásica. De los 17 libros de su Geografía tan sólo se han perdido algunas partes finales del libro VII. El intento de una descripción universal de la superficie terrestre conocida es extremadamente ambicioso.Sus libros están dedicados en este orden: I. Descripción general. II. Reconsideración y crítica de la geografía de Eratóstenes y de Hiparco. III. Geografía de Iberia. IV. Europa comprendida dentro del ángulo con vértice en la raíz de los Alpes que comprende desde la línea del Rhin -nacimiento-desembocadura- hasta los Pirineos en toda su longitud, 
10.- Quatre volumes in quarto dont POLYBE ${ }^{194}$, en espagnol, prisés huit francs, ci ........ 8

11.- Neuf volumes in quarto dont Histoire des Papes ${ }^{195}$, prisés douze francs, ci ............. 2

con las Islas todas del Atlántico, incluidas las Britaniae. V y VI. Italia y sus espacios dependientes. VII. Europa desde la línea del Rhin hasta Tais y la cordillera de los Urales, el valle del Danubio y el Ponto. VIII-X. Grecia y el espacio helénico. XI-XIV. Asia Anterior. - XV. Persia y la India. XVI. Asiria, Mesopotamia, Siria, Fenicia, Palestina y Arabia. XVII. Africa del Norte. STRABONIS de situ Orbis libri XVII, editi quidem in eorum gratiam, qui Geographiae studiosi sunt, olim (ut putatur) a Guarino Veronensi et Gregorio Trifernate latinitate donati. Recens vero a doctissimis viris quorum in Praefatione fit mentio, emendatiorem ..., Amstelodami: apud Joannem Janssonium, 1652, 2 vols. - Se comprende que, entre nosotros, el libro más veces traducido del latín o del griego -que fue su lengua originalhaya sido el que más directamente nos concierne: ESTRABÓN, Libro tercero de la Geografia que comprende un tratado sobre España antigua. Traducido del latín por Juan López, Madrid, Viuda de Ibarra, 1787, 3 h. $+30+290$ pp +1 mapa. - Entre las ediciones más prestigiosas, de las que Llorente pudo tener noticia, se cuentan las de Aldo -Venecia 1516-, Casaubon -Ginebra 1587 y París 1620-, Falconer-Oxford 1807-, Siebenkiess -Leipzig 1811-, Koray -París 1815-1818-.

194 Historia de POLYBIO Megalopolitano, traducida del griego por Ambrosio Rui-Bamba, Madrid: Imprenta Real, 1789, 3 vols. - La presencia de las páginas de Polibio (nacido en $210 \pm$ y muerto en 128 \pm ) entre otras obras literarias de la biblioteca de Llorente concuerda bien con la forma mentis historiológica del eclesiástico riojano. En efecto, Polibio es pionero, en varios niveles, del mester histórico. De su pluma salió la primera historia general que se haya escrito: cierto que tan sólo se extiende desde el 220 a.C. hasta el 141. Pero el intento recoge un afán enteramente nuevo, que no se contenta con seguir el filum de un pueblo -como Roma-, sino que analiza toda la red de pueblos coetáneos, profundiza en sus causas y en sus influjos recíprocos, compara sus instituciones y tiene en cuenta los niveles populares y las diversas idiosincrasias. Con respecto a la historia de España es igualmente pionero con su historia de Numancia, de los Cartagineses, de los Escipiones y de las campañas bélicas en general desarrolladas sobre la península ibérica, en una coyuntura histórica de gran alcance. Fue preceptor y amigo de Escipión Emiliano. Entre las mejores ediciones deben señalarse las de Casaubon, París 1609; y la de Schweighäuser, con notas, Leipzig 1789-1795. Llorente tenía las obras en castellano.

${ }_{195} \mathrm{Al}$ único a quien Llorente cita como autor de una Vida de los Papas es al cardenal Bartolomeo Platina, cfr. LlORENTE, Retrato político de los Papas desde San Pedro hasta Pio VII inclusive, con espresión del principio y fin de cada pontificado y reflexiones críticas en los que dan ocasión a ello, $\mathrm{I}$, Albán y compañía, Madrid 1823, 119. A ésta, pues -según creo-, se refiere el inventaire. Bartolomeo Platina (1421-1481), Platinae Hystoria de Vitis Pontificum: periucunde diligenter recognita \& nunc tantum integre impressa: Sixti IV, Innocentii VIII, Alexandri VI ac Pii III vita huic Platinae annexa: iamiam in lucem prodiens. Parisiis: impressum impensis honesti viri Francisci Regnault 1505, $8^{\circ}$ idus octobris. - Otra edición es la que se presenta con Raphäel VOLTERRANI (Raffaele Maffei de Volterra (1451-1522), Historia de vita quattuor Maximorum Pontificum, nuper edita, in fine posita. Venetiis: a Philippo Pincio Mantuano 1511, die $7^{\mathrm{a}}$ novembris. - Una tercera edición que manifiesta el prestigio de esta obra es la que ve la luz en Colonia Agripina: Eucharius Cervicornius excudebat. Impensis Gotfridi Hittorpii, 1540. - Para hacer accesible el criterio de Llorente a la hora de elegir sus fuentes y de documentarse, conviene anotar otros libros que conoció o debió de conocer: en primer lugar, la importante obra de A. CIACONIUS - así, con su nombre latinizado, cita H. Jedin a Alonso CHACÓN, ilustre dominico de Baeza y uno de los hombres más sabios de su tiempo, en opinión de los novatores españoles de fines del XVII-, Vitae et res gestae Pontificum Romanorum et S. R. E. Cardinalium, 2 vols. Roma 1601ss., terminado por F. CABRERA MORALES; en la segunda edición -1630-, A. VICTORELLI et alii amplían el arco hasta Clemente VIII; en la tercera, 4 vols., ibidem, 1677, A. OLDOINI llega hasta Clemente IX; en la cuarta, 6 vols. 1751, GUARNACCI la amplía hasta Clemente XII; la de 1787 consta ya de 7 vols. - No obstante, parece que Llorente no ha hecho demasiado aprecio de esta obra. Sin embargo, en el frontispicio de su Retrato politico de los Papas, declara que sus principales

Inquisidores contra la Inquisición

Hispania Sacra 55 (2003) 
12.- Douze volumes in quarto reliés, Histoire naturelle de PLINE ${ }^{196}$ prisés trente six

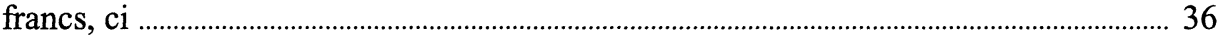

fuentes son las respectivas historias eclesiásticas del Cardenal Fleury y de Noel Alexandre así como «otras muchas acreditadas de muy exactas y verídicas entre los literatos más críticos». - Y así, a lo largo de las páginas del Retrato político, se citan diversos autores como José Isaac BERRUYER (1681-1758), Histoire du Peuple de Dieu depuis son origine jusqu'à la venue du Messie, Paris 1728. La obra consta de tres partes: 1) Histoire du Peuple de Dieu depuis son origine jusqu'à la venue du Messie, Paris 1728, con un suplemento añadido en 1734. 2) Histoire du Peuple de Dieu depuis la naissance du Messie jusqu'à la fin de la Sinagogue, Paris 1753; y 3) Histoire du Peuple de Dieu, ou Paraphrase des Epitres des Apôtres d'après le commentaire latin du P. Hardouin, Lyon 1757. Las tres partes de esta obra fueron puestas en el Índice. Buena parte del éxito editorial que consiguió esta obra en diversos países de Europa, desde la aparición de su primer tomo, se debió al escándalo provocado por sus afirmaciones y, sobre todo, por sus dudas sobre la divinidad de la Persona de Cristo. Llorente cita esta obra en español y en italiano: cfr. LLORENTE, Retrato político de los Papas desde San Pedro hasta Pio VII inclusive, con espresión del principio y fin de cada pontificado y reflexiones críticas en los que dan ocasión a ello, II, Albán y compañía, Madrid 1823, 267. - Cita también Llorente a los Maurinos, El arte de verificar fechas, cfr. Retrato político,c., I, 170. - La opinión de Llorente sobre los Maurinos es despectiva; dice: «sin embargo de ser muy píos», cfr. Ibidem, II, 99. Cfr. infra item 51, ad notam - Llorente cita también a PRUDHOMME (sigo ahora, al citar estos nombres propios, la grafía de Llorente sin corregirla) y a RAIMOND su compendiador (a ambos los considera prototipos del historiador insincero y con compromisos apriorísticos); a Lorenzo BARRET; a CEDRENO, historiador griego del siglo XII (I, c., 168); a ANASTASIO el Bibliotecario (contemporáneo de la «Papisa Juana»!) (I, c., 245); a ESPANHEIN, con su historia publicada en 1758; a SANTARELlA SJ (autor de Il Nepotismo di Roma, 2 tomos, s.d., 1667. Cfr. Retrato político, II, c.,138) y al cardenal Celestino ESFONDRATI (o SFONDRATI, autor del famoso Nodus praedestinationis dissolutus, que armó revuelo entre los teólogos de su tiempo aunque nunca llegó a ser censurado. Cfr. Retrato político II, 255); en fin, sin ser exhaustivo, a Eustaquio VIGNON, autor de Estado de la Iglesia en el discurso de los tiempos desde los apóstoles hasta nuestros días, París 1591. - Llorente no cita, que yo recuerde, a François BRUYS (1708-1738), Histoire des papes, depuis Saint Pierre jusqu'à Benoit XIII inclusivement, La Haye 1732-1734, 5 vols in $4^{\circ}$. Esta obra llena de calumnias fue repetidamente rechazada por su propio autor después de su conversión del calvinismo a la Iglesia Católica. Los mismos protestantes la desautorizaron por sus increíbles exageraciones. Cfr. J. CARREYRE en Dictionnaire d'Histoire et de Géographie Ecclésiastique, X, 989-990.

196 C. PLINII SECUNDI Historiae Mundi libri XXXVII: ex postrema ad vetustos codices collatione cum . adnotationibus et indice, Parisiis: apud Andonum Paruum..., 1543 (excudebat Michäel Fezandat). Cayo Plinio Segundo, llamado el Viejo, oriundo -según parece- del Norte de la península Itálica, de las comarcas de Como, donde la familia Plinia conservaba desde antiguo importantes posesiones, es uno de los escritores más prolíficos de la Antigüedad Clásica. Por su sobrino Plinio el Joven conocemos el elenco de sus obras. Pero la más importante y la única -creo- conservada íntegramente ha sido la anchurosa e interesantísima de los Naturae historiarum libri XXXVII, tantas veces editada, o bien en su totalidad o bien fragmentada, en libros sueltos. Plinio el Viejo es prestigioso también como infatigable en su curiosidad erudita y en su afán de transmitir sus conocimientos y experiencias. Notablemente ingenuo en bastantes ocasiones, proporciona habitualmente un arsenal de datos geográficos e históricos que todavía hoy conservan un horizonte de saber nada desdeñable. Amigo y conocedor de Hispania, donde estuvo un cuadrienio como Procurador de la Citerior y, más tarde, otro como Cuestor y Procurador del Erario de la Bética, establece una indeleble referencia para los investigadores de nuestras raíces históricas. Su positivismo investigador, su ingenuidad pagana, su panteísmo naturalista y su sinceridad moral le acarrearon prestigio en la época ilustrada, cuando la atención a la Historia Natural experimentaba un auge más que notable. Cfr. C. PLINII SECUNDI Naturalis Historiae libri XXXVII, cum ... adnotationibus Pintiani (et aliorum), Lipsiae, Impensis G.G. Sommeri 1778-1791, 10 vols. in-8. Hernán Núñez de Guzmán era 
13.- Trente six volumes in quarto reliés, Histoire Ecclésiastique de FLEURY ${ }^{197}$ prisés vingt quatre francs, $\mathrm{ci}$

(Suma total hasta aqui) ..................................................................................... 828 francs

(concluye la página recta de este folio con los «parafes» de validación)

/l

(Suma total hasta aqui)

828 francs

14.- Douze volumes in quarto reliés dont Histoire des guerres d'Italie ${ }^{198}$ et Histoire $d u$ Concile de Trente ${ }^{199}$, prisés quinze francs, ci

15.- Sept volumes in quarto dont Dictionnaire de l'academie ${ }^{200}$ et Dictionnaire BoISTE ${ }^{201}$, prisés dix huit francs, ci

conocido universalmente como El Pinciano. Cfr. Antonio PALAU y DulCET, Manual del librero hispano-americano desde la invención de la Imprenta hasta nuestros tiempos con el valor comercial de los impresos descritos, $2^{\text {a }}$. edición corr. y aum. por el autor, Barcelona: Palau, 1951, Plinio.

197 Claude FLEURY, Prêtre, Prieur d'Argenteuil \& Confesseur du Roi (1640-1723), Histoire Ecclésiastique, corrigée, comprenant en vingt-quatre volumes les trente-six des précédentes éditions, à laquele on a ajouté la Table générale de tout l'ouvrage, en forme de Dictionnaire, saisant le vintcinquième volume. A Paris: aux dépens des Libraires Associés, 1781, 24 vols. In-4, 26cm. Avec approbation et privilège du Roi.

${ }^{198}$ El título es muy famoso como para no conocer el libro de Francesco GUICCIARDINI (14831540), Histoires des guerres d'Italie... ecrite en italien par Messire François Guicciardini \& traduite en françois par Hierosme Chomedey. Revuée et corrigée de nouveau. À Paris, par Jaques Keruer 1577. - Otra edición de las Guerres d'Italie, en Londres/París: Chez Paul \& Isaac Vaillant, 3 vols. 1738. - Cfr. et. Francesco GUICCIARDINI, Opere, a cura di Vittorio de Caprariis, col. «La letteratura italiana. Storia e testi» xxx, Riccardo Ricciardi Ed., Milano/Napoli 1961, 1092 pp.

${ }^{199}$ Sin duda, la de Sarpi o, por usar el seudónimo, la de Pedro Suave o Petrus Suavis, Polonus, traducida a varios idiomas y puesta en el Index. Cfr. la edición dieciochesca: Paolo SARPI (15521623), Histoire du Concile de Trente, écrite en italien par --. --- (...) et traduite de nouveau en français, avec de notes critiques, historiques et theologiques, par Pierre-François Le Courayer, Chez J. Wetstein et G. Smith, Amsterdam 1751, 3 vols. Llorente la cita con aprecio en Retrato politico, II, c., 213. - Cfr. et. P. SfORZA PAllavicini, Istoria del Concilio di Trento, 2 tomos, Roma 1656-57. Su mejor edición es la de F.A. ZACCARIA, 5 tomos, Faenza 1792-1796. Llorente no oculta su antipatía por esta obra. «El jesuita Palavicino -escribe- imprimía en aquel tiempo la Historia del Concilio Tridentino contra la publicada por el servita fra Paulo Sarpi. Había impreso en ella más de veinte mil adulaciones al Papa para conquistar el capelo que logró efectivamente; pero las más personales eran el altísimo elogio del desprendimiento del nepotismo...». Retrato político, II, c., 245.

${ }^{200}$ La iniciativa de preparar un diccionario de la Academia Francesa se remonta a 1638 bajo el firmamento cultural cuyo mecenas político es el cardenal Richelieu. La iniciativa se les propuso a Vaugelas y a Chapelain, aunque seguidamente fue preferido Chapelain. Pero la obra surgía bajo el signo de la lentitud. La primera edición es Dictionnaire de l'Académie française: "ab Jove principium», Imprimérie royale 1694, con un préface de Charpentier. - La segunda edición -la de Régnier-Desmarais- es de 1718. - La tercera edición es de 1740. - La cuarta edición es de 1762. De ella dijo M. Villemain: «la quatrième édition est la seule importante pour l'histoire de notre idiome, qu'elle reprend à un siècle de distance des premières créations du génie classique, et qu'elle suit dans une époque de créations nouvelles; en géneral, elle a été retouchée avec soin, et, dans une grand partie, par la main habile de Duclos». P. LAROUSSE, Préface a Grand Dictionnaire, c., VII-VIII. - La quinta edición es la de 1798 (an VII).

201 P.-Cl.-Vict. BOISTE (literato y lexicógrafo, nacido en París en 1765 y muerto también en París el 24 de abril de 1824), publicó 3 diccionarios: Dictionnaire de Belles Lettres, Dictionnaire de Géo-

Inquisidores contra la Inquisición

Hispania Sacra 55 (2003) 
16.- Huit volumes in octavo reliés Oeuvres de VOLNEY202, prisés vingt francs, ci .... 20

17.- Sept volumes in octavo Histoire de Paris par DULAURE ${ }^{203}$ prisés trente francs, ci 30

graphie Universelle, y Dictionnaire Universel de la Langue Française, que, publicada su primera edición en 1800 , vio ya su $\mathrm{Vl}^{\mathrm{a}}$ edición en París: chez Verdière, 1823. Seguramente el inventaire se refiere a éste último diccionario. Lo sugiere la contigüidad con el Dictionnaire de l'Academie. Cfr. QUÉRARD, c. - P. Larousse, que juzga el dictionnaire de Boiste con bastante dureza, cuenta la siguiente anécdota: «Un matin de l'année 1805, un agent de police se présente chez Boiste, et lui exhibe un mandat d'amener qu'il était chargé d'exécuter. La résistance n'était pas possible; Boiste s'habille en toute hâte et se met à la disposition de l'agent, qui le fait monter dans un fiacre et lui conduit à l'hotel de Fouché, chef dela police impériale. Lorsque Boiste fut introduit, le ministre était dans un grand état d'exaspération, et il adressa au lexicographe les plus violentes apostrophes, l'accusant d'avoir outragé l'Empereur. Boiste, stupéfait, ne sait d'abord que repondre; cependant, il se rassure un peu et fait observer au terrible ministre qu'il n'est qu'un pauvre grammarien et qu'il ne s'est jamais occupé de politique. Le ministre s'irrite, et, pour confondre Boiste, il lui fait lire dans son propre dictionnaire: SPOLIATEUR, qui dépouille, qui vole --- trice: loi--- Bonaparte. - Tel était l'article qui outrageait la majesté impériale. On avait persuadé à Fouché que les qualifications injurieuses qui accompagnent le mot spoliateur s'appliquaient au nom de Bonaparte, tandis que l'auteur voulait simplement indiquer que Bonaparte avait consacré l'expression de spoliateur, et surtout celle du féminin, dans un discours public». P. LAROUSSE, $c$., XIV-XV.

202 Constantin-François Chasseboeuf, comte de VOLNEY (1757-1820) es uno de los más significados exponentes de la clase de los philosophes de la Ilustración. Bien conocido, ya a lo largo del XIX, como el autor de las Ruinas de Palmira, del que se hicieron numerosas ediciones, el Conde de Volney pertenece a la segunda generación de las Luces y puede considerarse como uno de sus más brillantes mentores. Su pensamiento - la verdad sea dicha- no sobrepasa en prestigio al transmitido por otras plumas filosóficas del racionalismo dieciochesco, que alternaron la política con el indoctrinamiento de la pujante burguesía y eligieron como utopía la felicidad de la humanidad. Sanchis Rivera -en el Diccionario de Ciencias Eclesiásticas de PERUJO y ANGULO- afirma que Las ruinas de Palmira «es una de las producciones más impías que han aparecido» $(\mathrm{X}, 473)$. Tal vez, este enjuiciamiento pudiera parecer exagerado, como todo lo que se afirma con ponderativos maximalistas. Pero tan severo enjuiciamiento no ha merecido corrección: «el profundo y analítico estudio que Volney hace de las diferentes religiones que en el mundo han sido -se ha escrito no hace tanto tiempo-, de su origen y desarrollo, es uno de los -más claros intentos de racionalizar las religiones y sus creencias, de desmitificación y objetivación de los entramados sociales creados por ellas. La ley de la naturaleza, la razón, se ha convertido en la regla de oro de la nueva filosofia naciente, de la que Volney es uno de sus más claros y brillantes propagadores, el hombre ya no necesita ninguna verdad revelada, ni credo sobrenatural, para organizar y explicar su existencia; sólo el progreso como fe y la razón como guía le conducen ahora al hombre a su destino: la felicidad de la humanidad». Presentación a C.F. VOLNEY, Las ruinas de Palmira o meditación sobre las revoluciones de los imperios, traducido por Joseph Marchena, Ed. El Museo Universal, Madrid 1985. Debe advertirse que todas las obras de Volney fueron puestas en el Índice. - Sobre otras ediciones recientes cfr.: VOLNEY, Oeuvres, "Corpus des oeuvres de Philosophie en langue française», Fayard, 3 tomes, Paris 1989 y 1998. - Cfr. et. el artículo que le dedica QUÉRARD, c. - Cfr. et. la bibliografia y el prudente enjuiciamiento acerca del Comte de Volney en Jean DE VIGUERIE, c., 1445-1446.

203 Jacques-Antoine DULAURE, Histoire physique, civil et morale de Paris, depuis les premiers temps historiques jusqu'à nos jours...; ornée de gravures représentant divers plans de Paris, ses monuments et ses édifices principaux. Seconde édition. Guillaume, Paris 1823,10 vols. - Pero la primera edición había comenzado a aparecer en 1821 y tenía 7 vols. - Cfr. QUÉRARD, $c$.

Inquisidores contra la Inquisición Hispania Sacra 55 (2003) 
18.- Dix neuf volumes tant in- $8^{\circ}$. qu'in douze dont Les Crimes des Papes $^{204}$, prisés dix francs, ci

19.- Dix sept volumes ouvrages diverses de DE PRADT ${ }^{205}$, dont les concordats et autres, prisés quinze francs, ci 15

20.- Douze volumes in octavo et in douze dont Remarques sur la langue françai$s e^{206}$ et Dictionnaire geographique ${ }^{207}$ prisés dix francs, ci

${ }^{204}$ Existía un volumen de Louis DE LA VICOMTERIE DE SAINT-SAMSON, Les crimes des papes, depuis S. Pierre jusqu'à Pie VI..., 1792, 1 vol. Cfr. Library of Congress Online Catalog.- Apareció algunas décadas más tarde la obra de Maurice LA CHÂTRE (1814-1900), Histoire des Papes: crimes, meurtes, empoisonnements, parricides, adultères, incestes: depuis saint Pierre jusqu'à Grégoire XVI: histoire des saints, des martyrs, des pères de l'Église, des ordres religieux, des conciles, des cardinaux, de l'Inquisition, des schismes, et des grands réformateurs: crimes des rois, des reines et des empereurs. Magnifique édition, splendidement illustrée de gravures sur acier, exécutées par nos prémiers artistes. Administration de librairie, Paris 1842-1844, 10 vols. Library of Congress Online Catalog.- Sin duda Llorente no poseyó esta edición, claro está; pero la aducimos como indicación de un fenómeno de extraordinario interés: podría decirse que el libro de La Vicomterie contiene in nuce el opus fusius de La Chatre, llamado a ser fusius et fusius. Entre ambos, se hallan estos 19 volúmenes del inventaire de Llorente, revelando toda una corriente que debió existir más o menos soterrada, manifestándose tal vez a través de brochures o de pamphlets, que pudieron ser recogidos por Llorente y encuadernados. A no ser que existiera ya a comienzos del XIX una obra más amplia que la ya citada de La Vicomterie, y que yo desconozco. Llama la atención la ausencia de estudios sobre el anticlericalismo adversus caput Ecclesiae, que ha constituido el más grosero de los anticlericalismos y que supera en mucho el complejo anti-romano de que habló H.U.von Balthasar. Cfr. v.g. René RÉMOND, L'anticlericalisme en France de 1815 à nos jours, Fayard 1976. - A la editora «Complexe» se debe una nouvelle édition augmentée et mise à jour, Bruxelles 1992. - Bien estructurada y completa contenida en el ámbito francés- es la monografia de Alec MELLOR, Historia del anticlericalismo francés (traducción de la Histoire de l'anticlericalisme français, de ed. Mame), Mensajero, Bilbao 1967. - El iter anticlerical a través de la literatura francesa es contemplado inteligentemente desde la flema británica: Joseph N. MOODY, The Church as Enemy. Anticlericalism in Nineteenth Century French Literature, Corpus Books, Washington/Cleveland 1968.

205 Domingo Alfonso de Pradt (1759-1837), fue vicario general de Rouen con el Cardenal de la Rochefoucauld; asistió a los Estados Generales, donde se distinguió por su ardorosa defensa de la Monarquía y del Antiguo Régimen. Se situó admirablemente con Napoleón, que le nombró Obispo de Poitiers y luego Arzobispo de Malinas. Nombrado embajador en Varsovia, allí le alcanzó la desgracia por sus discursos no bien medidos según la vara de Napoleón. Todavía tuvo tiempo de recuperar el carro de la gloria con los Borbones y disfrutó de prestigio como escritor durante la Restauración. Había sido uno de los obispos que abogaron ante el Papa, en 1810, por la dispensa del matrimonio de Napoleón. M. DE PRADt, Mémoires historiques sur la Revolution d'Espagne, Rosa, Paris 1816. - ID., L'Europe et l'Amérique en 1821, 2 vols., Béchet, Paris 1822.

${ }^{206}$ Louis PHILIPPON DE LA MADELEINE, Choix des remarques sur la langue française, extraits des meilleurs ouvrages en ce genre, Favre, Paris an X (1802), in-12 ${ }^{\circ}, 164$ pp.

${ }^{207}$ François Xavier DE FELLER, Dictionnaire géographique, $3^{\mathrm{e}}$. éd., F. Lemarié, Liége 1794. También P.C.V. BoISTE (que ya ha sido citado ya anteriormente se ha citado), Dictionnaire de géographie universelle, Desray, Paris 1806. - Restringido al ámbito francés, Abbé Jean-Joseph D'EXPILLY, Dictionnaire géographique, historique et politique des Gaules et de la France, Paris 1762-1770, 6 vols. El séptimo, prometido, quedó sin publicar por inacabado.

Inquisidores contra la Inquisición

Hispania Sacra 55 (2003) 
21.- Huit volumes in octavo dont Dictionnaire de LAVEAUX ${ }^{208}$, prisés douze francs,

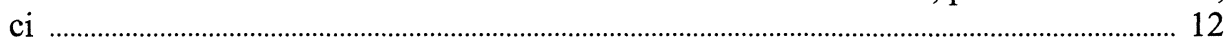

22.- Sept volumes in octavo reliés Dictionnaire des Rimes de RICHELET ${ }^{209}$ et Dictionnaire grammatical ${ }^{210}$, prisés dix francs, ci ................................................................... 11

23.- Vingt cinq volumes dont Histoire de la maison de Montmorency ${ }^{211}$, prisés cinq francs, ci

24.- Vingt volumes dont Dictionnaire de Paris ${ }^{212}$ et Les cinq $\operatorname{codes}^{213}$, prisés six francs, ci

208 Jean-Charles THIBAULT DE LAVEAUX (Troyes 1749-Paris 1827), Dictionnaire raisonné des difficultés grammaticales et littéraires de la langue française, Lefèvre, Paris $1818,810 \mathrm{pp}$.

209 Cesar-Pierre RICHELET, Dictionaire (sic) de rimes, dans un nouvel ordre, où se trouvent: I. Les mots \& le genre des mots. II. Un abregé de la versification. III. Des remarques sur le nombre des syllabes de quelques mots difficiles. Par --- ---. Nouvelle édition. Augmentée d'un grand nombre de mots françáis \& de tous les mots latins par M.D.F. en faveur des étrangers \& de ceux qui veulent apprendre par raison \& proportion la langue latine, Paris: chez la Veuve Delaulne, 1731. - La primera edición llevaba por título Nouveau Dictionnaire de Rimes, Paris: chez Courbé, 1648. - La parte teórica va en francés y latín.

210 Los religiosos de Port-Royal dieron un impulso decisivo a la lexicografía y determinaron el desarrollo de una curiosidad científica y de una seria actividad crítica en torno a la maravilla del lenguaje humano. Aplicando una rigurosa lógica a la filosofia de la comunicación humana transformaron el estudio de la gramática haciendo de ella no tanto un conjunto de reglas y métodos cuanto una vereda de profundización en el espíritu del hombre y de conocimiento y análisis del Universo. Surgieron así muchas obras que transformaban la gramática en un saber crítico. Un hito en la evolución de la comprensión gramatical surgida del seno mismo de la Ilustración y de la Aufklärung es el JohannChristoph ADELUNG (1732-1786), Grammatisch-kritisches Wörterbuch der hochdeutschen Mundart, $2^{\text {a }}$ ed., J.G.I. Breitkopf, Leipzig 1793-1801, 4 vols. La obra, desde que apareció su primera edición también en Leipzig 1774-1786- atrajo la atención y suscitó aceradas discusiones. - Sin llegar a lo que iba a ser pocos años más tarde el Grammatisch-kritisches Wörterbuch, verdadera pretensión de codificar el lenguaje, racionalismo puro y duro, en Francia había aparecido el P.J.-Fr. FÉRAUD, Dictionnaire grammatical de la langue française, nouvelle édition corrigée et considérablement augmentée, chez Vincent, Paris 1968.

211 André DU CHESNE, Histoire généalogique de la maison de Montmorency et de Laval, justifiée par chartes, titres, arrêts, et autres bonnes et certaines preuves; enrichie de plusieurs figures et divisée en XII livres, Paris: chez S. Chamoisy 1624. - J.-L. Ripault DÉSORMEAUX, Histoire de la maison de Montmorency, Paris 1764, 5 vols. in-12 $2^{\circ}$ - Hay otra edición de 1784. - Esta misma obra ha vuelto a ser reeditada en Strasbourg: chez S. Pastéris, 2000, 2 vols.

212 DUFEY \& BERAND, Dictionnaire historique de Paris, 1822,2 vols. in- $8^{\circ}$. - J. DE LA TYNNA, Dictionnaire topographique, étymologique et historique des rues de Paris, 1816, in-12 ${ }^{\circ}$. -HURTAUX \& MAGNY, Dictionnaire historique de la ville de Paris et de ses environs, 1779, in- $8^{\circ}$. - LACOMBE \& PREZEL, Dictionnaire du citoyen, 1761 , in- $8^{\circ}$.

${ }^{213}$ Les cinq codes de l'Empire français: Code Napoléon, code de procédure, code de commerce, code criminel, code pénal; suivis de la taxe des frais et dépens civile et criminelle, et d'une table alphabétique des matières, réunis en un seul volume, pour l'utilité des gens de loi, propriétaires, négociants et employés des administrations, $4^{\mathrm{a}}$. éd. conforme à celles de l'Imprimerie impériale, Le Prieur libraire, Paris 1812, 708 pp. - Les cinq codes, nouvelle édition, Chez Mame, Tours 1821. - Las ediciones de los cinco códigos fueron muy numerosas. 
25.- Quarante volumes tant in douze qu'in dix huit dont Excellence de la langue $e^{214}$, prisés trois francs, $\mathrm{ci}$

26.- Vingt cinq volumes dont Histoire des amnisties ${ }^{215}$ prisés trois francs, ci .......... 3

27. Vingt cinq volumes tant in douze qu'in dix huit dont Histoire des humblemens de terre et tombeau d'HERVEY ${ }^{216}$, prisés trois francs, ci ...................................................... 3

28.- Trente volumes in douze et in dix huit dont Biographie des souverains ${ }^{217}$, Le bon sens ${ }^{218}$, prisés six francs, ci

214 Antonio de CAPMANY, Observaciones críticas sobre la excelencia de la lengua castellana en ID., Teatro histórico-crítico de la elocuencia castellana, I, pp. CXXII-CCXXIII (inmediatamente después del Discurso preliminar), Imprenta de Antonio de Sancha, Madrid 1786. - Que yo sepa las Observaciones nunca se publicaron en edición independiente del Teatro crítico-histórico -al que precede-, antes de la anotada por Francisco MERINO BALLESTEROS, en Biblioteca universal, «Colección de los mejores autores antiguos y modernos, nacionales y extranjeros», t. 177, Madrid 1920. - Actualmente, la más accesible edición es la de Carlos CABRERA MORALES, Edición, introducción y notas a Antonio de CAPMANY, Observaciones críticas sobre la excelencia de la lengua castellana, Universidad de Salamanca 1991. - Cfr. et. Françoise ÉTIENVRE, Rhétorique et Patrie dans l'Espagne des Lumières. L'oeuvre linguistique d'Antonio de Capmany (1742-1813), Honoré Champion, Paris 2001, 200-211.

${ }^{215}$ No es fácil saber el género literario ni el título exacto de estos veinticinco volúmenes. La tratadística histórica de las amnistías se desarrolla -creo- más tardíamente. Ni el Dictionnaire Universel de Larousse, ni el Dictionnaire de Diderot dan otra cosa que una magra recensión de las más célebres amnistías clásicas. El Dictionnaire historique et critique de Bayle ni siquiera le dedica atención. Llorente que tanto suspiró por su retorno a la Patria seguramente reunía cuantos escritos propios o ajenos hacían referencia a tema tan vital. Esos escritos, una vez encuadernados, sumaban -qué duda cabe- un buen acervo de volúmenes. Pienso - una vez más lo afirmo- que, de esos tomos, muchos contenían asuntos repetidos con ánimo de venderlos o de hacer intercambios: en una época en que el comercio de segunda mano estaba a la orden del día. - Por otra parte, ¿qué pensar del contenido de 25 volúmenes que en su conjunto fueron tasados en 3 francos?

216 James HERVEY, (1714-1758), teólogo y moralista inglés. Próximo al naciente movimiento metodista, aunque nunca se afilió a él; pero se mantuvo bajo su influjo y colaboró con sus escritos a extender una sensibilidad religiosa y unos argumentos a favor del movimiento que tuvieron convocatoria y contribuyeron a su expansión. Las páginas de Hervey no son de buen gusto literario. Pero fueron editadas muchas veces. El más famoso de sus libros es Meditations and Contemplations. Containing meditations among the tombs, reflections on a flower garden, and a descant on creation, 1746 in $8^{\circ}$. Fue traducido al francés por Letourneur, Paris: chez Lejay 1770 , in- $8^{\circ}$. et in- $12^{\circ}$. y por $\mathrm{M}^{\mathrm{me}} \mathrm{G}$.$\mathrm{Ch}$. Thiroux d'Arconville, Paris 1771 , in- $12^{\circ}$. Tanto en italiano como en francés corrieron traducciones traducidas en verso, que se leían con gusto todavía a finales del XIX. Cfr. M. le $\mathrm{D}^{\mathrm{r}}$. HOEFER (dir.) y MM. FIRMIN-DIDOT et $\mathrm{C}^{\mathrm{ie}}$. (édit.), Nouvelle biographie générale depuis les plus reculés jusqu'à nos jours, avec les renseignements bibliographiques et l'indication des sources à consulter, Paris, 1877.

${ }^{217}$ Se trata probablemente del libro anónimo Biographie universelle des souverains qui ont péri de mort violente ou Histoire abrégée de leur règne et des causes et circonstances de leur mort..., Paris: P. Mongié aîné 1820,2 vols. in- $16^{\circ}$. - Otras biografías de los soberanos del siglo XIX, o de Europa, o de los miembros de la Familia Real Francesa desde la revolución, son posteriores a la muerte de Llorente.

218 Jean-Baptiste DE BOYER, MARQUIS D’ARGENS (1704-1771), La Philosophie du bon sens, ou Réflexions philosophiques sur l'incertitude des connoisances humaines, à l'usage des cavaliers et du beau sexe. Nouvelle édition... augmentée d'un examen critique des remarques de M. l'abbé d'Olivet... sur la théologie des philosophes grecs, Dresde: C. Walter $1769,12^{\mathrm{e}}$. éd., 2 vols. in- $8^{\circ}$. - Primera edi-

Inquisidores contra la Inquisición

Hispania Sacra 55 (2003) 
29.- Neuf volumes in octavo dont Histoire $d u$ monde primitif219, prisés douze francs, ci ........................................................................................................................ 12

30.- Vingt volumes in octavo reliés dont Puissance temporelle des Papes ${ }^{220}$, Histoire ecclésiastique de MOSHEN (sic) ${ }^{221}$ prisés vingt francs, ci ......................................... 20

31.- Trente volumes in douze et in dix huit dont Voyages aux Indes ${ }^{222}$ prisés quatre francs, ci .

ción: La Haye, chez P. Paupie, 1746, 2 vols. in-12 ${ }^{\circ}$. Fue gran amigo de Federico II de Prusia hasta que rompió con él por recíproca incomprensión y por el rechazo caprichoso del monarca. Aunque el estilo y la elevación de pensamiento no son la nota más apreciable de las páginas de Argens, sin embargo Voltaire y otros «philosophes des Lumières» apreciaron mucho su escepticismo universal y su carácter descomprometido. El libro -dicho sea en honor a la verdad- no carece de páginas de notable interés.

${ }^{219}$ Isoard-Jean-Baptiste-Claude DELISLE DE SALES (1743-1716), Histoire philosophique du monde primitif, Paris: (s.n.) 1793, 7 vols. in- $8^{\circ}$. Reedición informática: Paris 1995. - Delisle de Sales había nacido en Lyon. Pasó un tiempo en el Oratorio de San Felipe Neri; pero, tras renunciar a ese camino, se comprometió con extraordinario entusiasmo en un dilatado campo de intereses eruditos y librescos. Su obra más célebre -por la que se vio metido en dificultades y en la misma cárcel- es Philosophie de la nature ou Traité de morale pour l'espèce humaine, 1770.

${ }^{220}$ François SABBATHIER (professeur au collège de Châlons-sur-Marne), Essai historique-critique sur l'origine de la puissance temporelle des Papes, La Haye/Châlons-sur-Marne: chez A. Degaulle, 1765, in- $8^{\circ}$, VI $+164+10$ pp. - Francesco GUICCIARDINI, Essai historique sur la Puissance temporelle des Papes (traduit par Turpetin de l'éd. de Fribourg 1775, in-4 ${ }^{\circ}$ ), Paris 1810. - Pierre-Claude-François DAUNOU, Essai historique sur la puissance temporelle des Papes, sur l'abus qu'ils ont fait de leur ministère spirituel, et sur les guerres qu'ils ont déclarées aux souverains, spécialement à ceux qui avaient la prépondérance en Italie, Paris: Le Normand, $2^{\mathrm{e}}$. éd. 1810 , in- $8^{\circ}, 383$ pp. - Jules GARINET, De la puissance temporelle des Papes et du concordat de 1817, Paris: F. Bechet 1818 , in- $8^{\circ} .$, IV +91 pp.

221 Johann Lorenz VON MOSHEIM, Histoire ecclésiastique ancienne et moderne, depuis la naissance de Jesus-Christ jusqu'àu commencement du XVIII ${ }^{e}$ Siècle, traduite de l'original latin... par Archibald MacLaine... et de l'Anglois en François, sur la seconde édition rev. \& augm. ...par Maestricht: Chez Jean-Edme Dufour \& Philippe Roux, 1776. - Mosheim (muerto en 1755) pasa por ser el «padre de la historia eclesiástica protestante» abriendo paso a un estudio científico de la entera historia de la Iglesia. Para Mosheim la historia eclesiástica debía ser «la narración discreta y veraz detodos los acontecimientos internos y externos en aquella sociedad de hombres que debe su nombre a Cristo, a fin de reconocer por la ilación entre causa y efecto la providencia divina que obra en su fundación y conservación y hacerse así piadoso y sabio.» Estas palabras no deben entenderse prout sonant y descontextualizadas. El propio Mosheim no puede ser entendido sino a partir del proceso iniciado por Gottfried Arnold en su Unpartheische Kirche und Ketzerhistorie (1699). Arnold «desinstitucionaliza la historia de la Iglesia y se interroga sobre todo por la fe cristiana que procede del nuevo nacimiento. Partiendo de aquí se contempla en movimiento constante la forma de todo lo dado, de manera que la idea de historia resulta posible, desde su arranque, como historia de la formación del hombre.» Se ven, por tanto, algunas proximidades a Arnold por parte de algunas antropologías surgidas con gran éxito en el novecento. Por lo que hace a Mosheim, él «pretende una exposición pragmática de la historia de la Iglesia, es decir, sin dogmas, que esté acorde con los hechos, y excluye la historia de la Iglesia del campo de la teología.» Hubert JEDIN, Manual de Historia de la Iglesia, Herder, Barcelona, I y VI, 1966-1978, pp. 75 y 764 respectivamente.

222 En el Contenu des fonds Lambert et Durand achetés par Panckoucke en 1762-1764 aparece Le Voyage aux Indes, par HERNÁNDEZ (Cfr. TUCOO-CHALA, c., 522). Se trata sin duda de la célebre obra de Alvar NÚÑEZ CABEZA DE VACA, La relación y comentarios del gouernador Aluar nuñez cabeza 
32.- Vingt cinq volumes dont Histoire des inquisitions ${ }^{223}$ et Almanacs $\left(\right.$ sic $\left.^{224}\right)$ Royaux $x^{225}$ tant in douze qu' in octavo, prisés dix francs, ci .................................................. 10

33.- Dix sept volumes in douze, reliés en parchemin, dont Voyages en Espagne ${ }^{226}$, en espagnol, prisés douze francs, ci .......................................................................................... 12

de vaca, de lo acaescido en las dos jornadas que hizo a las Indias.- Commentarios de Alvar Nvnez cabeza de vaca, adelantado y gouernador de la prouincia del Rio de la Plata. Scriptos por Pero HERNANDEZ scriuano y secretario de la prouincia. Y dirigidos al Sereniss. muy alto y muy poderoso señor el Infante don Carlos N. S., Impresso en Valladolid por Francisco Fernandez de Cordoua. Año de mil y quinientos y cinquenta y cinco años. In- $4^{\circ}$., caracteres góticos en pergamino. Conviene hacer constar aquí el comentario de Leclerc: «Magnifique exemplaire dans sa reliure originale et avec témoins. C'est certainement un des plus beaux qui existe». - La Relación -se nos dice- había ya sido impresa en Zamora en 1542. En Francia se le conoce sobre todo por la traducción -aparecida quince años después de la muerte de Llorente- de H. TERNAUX- COMPANS, Voyages, Relations et Mémoires originaux pour servir à l'histoire de la découverte de l'Amérique; publiés pour la prémière fois en français par --- ---, Paris, Arth. Bertrand, 1836-1838, in- $8^{\circ}$. Los Commentaires d'Alvar Nuñez Cabeça de Vaca ocupan enteramente el tomo IV de esta colección (1838). Cfr. Ch. LECLERC, Bibliotheca americana. Histoire, géographie, voyages, archéologie et linguistique des deux Amériques et des Iles Philippines, Paris: Maisonneuve et $C^{\mathrm{ie}}$., 1878, 651-652.- Cfr. et. QUÉRARD, c.

223 Joseph LA VALLÉE, MARQUIS DE BOIS-ROBERT (1747-1816, revolucionario desde el mismo 1789, Jefe de División de la Gran Cancillería de la Legión de Honor, exilado en Inglaterra a la llegada de la Restauración), Histoire des inquisitions religieuses d'Italie, d'Espagne et de Portugal, depuis leur origine jusqu'à la conquête de l'Espagne, Paris: Capelle et Renaud, 1809, 2 vols in- $8^{\circ}$

224 Por almanachs

225 Almanach royal et national pour l'an ----, Paris: Chez Gayot et Scribe. - El almanach era un obsequio preciado. El Almanach de Gotha, por ejemplo, se editaba con abundantes datos políticos, nobiliarios, diplomáticos, con preciosos grabados, en encuadernación muy cuidada, con canto dorado y con su funda para evitar deterioros. Su pequeño tamaño lo hacía encantador como cadeau. El ejemplar, de 1824, que tengo ante mis ojos va dedicado a su esposa -una dama bien entrada en sus cincuenta años- por un esposo enamorado. Dice: 1 . Il n'est pas bien aisé, vraïment, / De vous fêter à votre guise: / Vous n'aimez ni le changement, / Ni les cadeaux, ni la surprise. - 2. De Gotha l'Almanach vous plait: / Le voilà: c'est toujours le même, / Avec mon éternel couplet, /Et mon vieux refrain: Je vous aime. - 3. J'ai beau chercher dans ce livret, / Quelque brillant anniversaire: / C'est celui du premier feuillet (en la primera página está escrito: «Rose Marie Henriette d'Ivernois, née de Sandoz, le $7^{\mathrm{me}}$ Décembre 1769») / Que mon cœur constamênt préfère. - 4. A ce propos doux et flatteur, / N'allez pas faire une méprise, / Et prendre pour un séducteur / Un vieil époux à barbe grise. Almanach de Gotha pour l'année ----, Gotha: Justus Perthes. Comenzó en 1764.

${ }^{226} \mathrm{La}$ literatura de viajes es extraordinariamente generosa. Por eso no es fácil aventurar cuál podría ser el ejemplar significado en este asiento de la biblioteca de Llorente. No obstante conviene señalar, siguiendo a Foulché-Delbosc, que los tres más importantes relatos de viajes a España, publicados en Francia y escritos en francés durante el siglo XVII, son los de Brunel (1655), Bertaut (1659) y Madame d'Aulnoy (1679). Cfr. «Revue Hispanique» 47 (1919) p.1. Los tres están publicados, con toda la documentación necesaria, en dicha revista: a) Voyage d'Antoine Brunel en Espagne, Rev Hisp 30 (1914) pp. 117-375. - 2) Journal du voyage d'Espagne fait l'année 1659 à l'occasion de la Paix, Rev Hisp 47 (1919) pp. 1-317. 3) Madame d'Aulnoy et l'Espagne. Relation du voyage d'Espagne, Rev Hisp 67 (1926) (todo el número). -Y ya en el siglo XVIII, entre otros libros famosos de viajes por España -de aquellos libros que un bibliófilo erudito hubiera deseado poseer-, valga recordar el Viage de AMBROSIO DE MORALES por orden del rey D. Phelipe II a los reynos de León y Galicia y principa-

Inquisidores contra la Inquisición

Hispania Sacra 55 (2003) 
(Suma total hasta aquí) 1052 francs /I

34.- Quatorze volumes petit in douze reliés, Description de l'Espagne ${ }^{227}$, en espagnol, prisés douze francs, ci

35.- Vingt cinq volumes tant in octavo qu'in douze, espagnol et portugais, dont Essai sur une bibliothèque espagnole ${ }^{228}$, prisés six francs, ci ................................................... 6

36.- Trente volumes tant in douze qu'in dix huit, dont Délices de l'Espagne ${ }^{229}$, en espagnol et portugais, prisés quatre francs, ci

do de Asturias... /Dale a luz, con notas ...Fr. Henrique Flórez, en Madrid: por Antonio Marín 1765, XXVI + 224 pp. (Nótese que Ambrosio Morales había vivido de 1513 a 1591. - Enrique Flórez, sin embargo, de 1702 a 1773). - Antonio PONZ, Secretario de la Real Academia de San Fernando, Individuo de la Real de la Historia y de las Reales Sociedades Bascongada, y Económica de Madrid, etc... (1725-1792), Viage de España: en que se da noticia de las cosas más apreciables y dignas de saberse que hay en ella, Reproducción facsímil de la de Madrid 1787, $2^{\text {a }}$. Edición corregida y aumentada, por la Viuda de Ibarra, Hijos y Compañía, Madrid 1787. T. XI, de una col. s.l. y s.n., 1990 ( ?). Cfr. et. R. FOULCHÉ-DELBOSC, Bibliografia..., c. - Llorente asegura: «En mis viajes he solido escribir Diarios. Entre mis papeles de París se podrán hallar los del viaje a Valencia, Zaragoza y Francia. Entre los de España, el de Bayona del año 1808, que contiene algunas noticias interesantes para la historia de la revolución española». Juan Antonio LlORENTE, Noticia Biográfica (Autobiografía) con una «Nota crítica» de A. Márquez y un «Ensayo bibliográfico» de Emil Van der Vekene, Taurus, «La otra historia de España», Madrid 1982, 136. - Se comprende, pues, que la afición da sentido a los libros de viaje en su Biblioteca. Afición, por lo demás, refinada y muy propia de la Ilustración.

${ }^{227}$ Abu Abdalah ben Mohamed al-Edrisi, Descripción de España de XERIF ALEDRIS, conocido por EL NUBIENSE, con traducción y notas de don Josef Antonio Conde, de la Real Biblioteca. De orden superior. Madrid en la Imprenta Real, 1799, XX + 234 pp. - Edición facsímil, Atlas, Madrid 1980.

228 Juan SEMPERE Y GUARINOS, Ensayo de una biblioteca española de los mejores escritores del reinado de Carlos III, Madrid en la Imprenta Real, 6 vols., 1785-1789. - Hay facsímil de esta primera edición, por la Junta de Castilla y León. Consejería de Educación y Cultura, responsable del texto Teófanes Egido, Salamanca 1997.

${ }^{229}$ Deliciae lvsitano-hispanicae: in quibus continentur De magnitudine Hispanici Imperii relatio: Noui Orbis regionum a Lusitanis subactarum breuis descriptio. De Lusitania ceterae Hispaniae adjuncta historia. Itemqve Lvsitaniae antiqvitates ab Andrea RESENDIO collectae..., Coloniae Agrippinae, apud Gerhardum Greuenbruch, 1613. - Cfr. et. Juan ALVAREZ DE COLMENAR, Les délices de l'Espagne et du Portugal où l'on voit une description exacte des antiquités, des provinces..., Leyde, Van der Aa, 1707, 4 vols. in $8^{\circ}$. En 1715 sale otra nueva edición, también en Leyde, de 6 vols. in $12^{\circ}$. - Véase por ejemplo otra obra de análogo contenido, referente a Italia: Sieur DE ROGISSART, Les délices de l'Italie, contenant une description exacte du païs, des principales villes, de toutes les antiquitez \& de toutes les raretez qui s'y trouvent: Ouvrage enrichi d'un très-grand nombre de figures en taille-douce, 4 vols., A Paris: chez Guillaume Cavelier, 1707. -Las obras impresas que se presentan bajo el título de Delicias son numerosas. Les délices de France, en seis volúmenes, hablan de alimentos y delicias del comer y beber. Sin embargo, véase esta otra, de contenido espiritual y jansenista: Antoine-Adrien LAMOURETTE (17421795), Las delicias de la religión cristiana, ó, El poder del Evangelio para hacernos felices, traducción de la obra que escribió en lengua francesa el señor abate ------, $2^{\mathrm{a}}$ edición corregida, Madrid: Cano, 1802, XVIII + 396 pp. - O esta otra del exagerado vate François DE ROSSET, Les délices de la Poésie française, Paris 1615. 
37.- Vingt sept volumes in douze reliés, dont la Vie de Philippe deux ${ }^{230}$, et celle d'Alexandre six ${ }^{231}$, prisés cinq francs, ci 5

38.- Treize volumes petit (sic) in octavo, reliés en parchemin dont Histoire de l'Aragon et des Codes $^{232}$, en espagnol, prisés neuf francs, ci

230 Antonio DE HERRERA Y TORDESILLAS (i1549 ? - 1625), Historia del mundo ... del tiempo del señor Rey Don Felipe II, 3 vols., Madrid 1601-1612. - Luis CABRERA DE CÓRDOUA (1559-1623), Filipe II, Rey de España, Primera parte, Madrid: L. Sánchez, impresor del Rey, 1619, 1182 pp. Esta obra consta de dos partes: la primera (recién citada), es la única que se publicó en vida del autor: comienza con el nacimiento de Felipe II (1527) y llega hasta 1583; la segunda, que alcanza ya el año 1598, no se publicó porque los diputados de Aragón pidieron a su Majestad que no se publicase hasta corregir algunos pasajes referentes a los sucesos ocurridos en aquel reino en 1591. El encargado de la enmienda fue Bartolomé Leonardo de Argensola. Pero el autor se negaba a cualquier corrección de su escrito. Así fue como las páginas de la segunda parte quedaron inéditas hasta 1876, año en que fue publicada por primera vez la obra completa. Es obvio que Llorente no llegó a conocer esta edición. - Cfr. et. ID., Historia de Felipe II, Rey de España, edición de José Martínez Millán y Carlos Javier de Carlos Morales, Junta de Castilla y León. Consejería de Educación y Cultura, 3 vols. 1998, 1711 pp. - Cfr. et. JOANNIS GENESII SEPULVEDAE (JUAN GINÉS DE SEPÚlVEDA, ..., De rebus gestis Philippi II, en ID., Opera, cum edita tum inedita, accurante Regia Historiae Accademia, vol. III, Matriti, ex Typographia Regia de la Gazeta, 1780, in- $4^{\circ}$.

${ }^{231}$ Vida de Don Rodrigo Borgia, luego Papa Alejandro VI, y de César Borgia y hermanos, hijos de dicho Pontifice, junto con las memorias de los más secretos acontecimientos que sucedieron durante el mencionado pontificado, el todo tomado de los manuscritos de la Biblioteca Vaticana. Este documento anónimo - presente con variantes en muchas bibliotecas- es la primera biografia del papa Alejandro VI: erróneo en muchos de sus datos, pero tradicionalmente copiado por unos y por otros -lo citen o no lo citen. Cfr. Orestes FERRARA, El Papa Borgia, La Nave, Madrid 1943, 34-36. - Alexandre GoRdON, Les vies du Pape Alexandre VI et de son fils César Borgia contenant les guerres de Charles VIII et de Louis XII en Italie, de 1492 à 1506, traduction de l'anglais, Amsterdam: Mortier, 1732, 3 vols. in-12 ${ }^{\circ}$. La primera edición inglesa es de 1729. Nótese la analogía del título de esta obra con el manuscrito primeramente citado. Ésta es, seguramente -a juzgar por la época de edición-, la obra que Llorente conservaba.

232 El monumento máximo es Geronimo ÇURITA, Anales de la Corona de Aragon compuestos por ---------, Çaragoça: Pedro Bernuz \& Domingo Portonarijs y Vrsino, 1562-1579. La obra consta de dos partes en 4 vols. in-folio de 5 libros cada uno. Concluye con la Historia del Rey Don Hernando el Catolico ..., Çaragoça, Domingo Portonarijs y Vrsino 1580, 2 vols in-folio con 5 libros cada uno. Total 6 vols. conteniendo 30 libros. (Noticia de A. Palau y Dulcet, c.). Otra edición eximia es la de Geronimo ÇURITA, Anales de la Corona de Aragon compuestos por --------, Chronista de dicho Reyno. Va añadida de nuevo, en esta impresión, en el último tomo, una apología de Ambrosio de Morales, con un parecer del Doctor Juan Páez de Castro, todo en defensa destos Anales. Con licencia y privilegio. Impressos en Çaragoça, en el Colegio de San Vicente Ferrer, por Lorenço de Robles, Impressor del mismo Reyno, año 1610. A costa de los administradores del General. El tomo II impreso por Juan de Lanaja y Quartanet. - Para noticia detallada sobre la evolución editorial de esta obra magna, cfr. A. PALAU Y DULCET, $c$., XXVIII, $2^{\mathrm{a}}$ ed. corr. y aum. por el autor. Revisada y añadida por Agustín Palau, Vicedirector de la Biblioteca de la Universidad Complutense, Palau Dulcet, Barcelona/ The Dolphin Book, Oxford, 1977, 473-476.- En la Biblioteca Nacional de Francia obra también la cuarta impresión de los Anales de Zurita de 1668. Llorente era buen conocedor de la Historia de España y de Aragón y, de hecho, Zurita se halla citado repetidamente en sus obras. - De los Anales de Zurita así como de los Índices de las gestas de los Reyes de Aragón existen hoy óptimas ediciones preparadas por Ángel Canellas en la «Institución Fernando el Católico» del CSIC. - En cuanto a les codes, lo que se contiene bajo este item son, muy probablemente, ediciones de los diversos textos históricos de diversos centros forales de Aragón: Jaca, Teruel, Albarracín, Daroca, Calatayud etc...,

Inquisidores contra la Inquisición

Hispania Sacra 55 (2003) 
39.- Quinze volumes in octavo reliés, dont Voyage littéraire en Espagne ${ }^{233}$, en langue espagnoles $\left(\mathrm{sic}^{234}\right)$, prisés dix francs, ci .................................................................... 10

40.- Dix huit volumes, tant in douze qu'in dix huit, reliés, dont Don Quichotte en espagnol, prisés neuf francs, ci

... 9

41.- Quinze volumes in douze dont Histoire de Charles Quint ${ }^{235}$, prisés six francs, ci

42.- Vingt quatre volumes dont Histoire des Canaries ${ }^{236}$ et Révolution d'Espagne, prisés quatre francs, ci

43.- Quinze volumes in quarto, reliés en parchemin, en espagnol, Théâtre critique et universel ${ }^{237}$, prisés dix francs, ci

además del Fuero de Huesca.- Para comprender la magnitud de este campo de estudio, cfr. Jesús Delgado ECheverRíA, Los Fueros de Aragón, col. «Mariano de Pano y Ruata», Caja de Ahorros de la Inmaculada de Aragón, Zaragoza 1997, donde con excelente presentación se recoge la historia de los Fueros aragoneses, de sus más prestigiosas ediciones y de los estudios histórico-jurídicos sobre ellos. -Cfr. et. Sobre la historia de Aragón y otros prólogos: antología de algunos escritos de Eloy FERNÁNDEZ CLEMENTE, Departamento de Educación y Cultura, Gobierno de Aragón, Zaragoza 1995.

233 Seguramente se trata de la obra de Jaime VILlANUEVA, Viage literario a las iglesias de Espa$\tilde{n} a$, Madrid en la Imprenta Real 1806. Muy bien advierte Vicente Llorens que el Viaje literario a las Iglesias de España es el fruto de las investigaciones de Jaime Villanueva en Archivos de Aragón y Cataluña desde principios de siglo. Al emigrar en 1823 había publicado diez tomos de su obra. Los restantes hasta 22, vieron la luz entre 1850 y 1852.» Cfr. A. ALCALÁ GALIANO, Literatura Española del siglo XIX, c., 57; y la nota de Llorens 148-149. - Jaime Villanueva, hermano de Joaquín Lorenzo había nacido en Játiva en 1765 y muerto en Londres en 1825. Llorente, por tanto, comprador en librerías de viejo o en puestos de ocasión, encuadernaba bajo su responsabilidad los libros: gusto de bibliófilo. Pero el notario no hace explícitos con la conveniente precisión que desearíamos, los títulos de las partes contenidas bajo el lomo o las tapas de una misma colección encuadernada.

234 Por espagnole

235 Fray Prudencio DE SANDOVAL, Obispo de Pamplona, Historia de la vida y hechos del Emperador Carlos $V . . ., \mathrm{I}^{\mathrm{a}}$ y II $\mathrm{a}$ parte, Nueva impressión enriquescida con lindas figuras, en Amberes: GeronymoVerdussen..., 1681. - Cfr. et. ID., Historia de la vida y hechos del Emperador Carlos V, máximo, fortísimo, Rey Católico de España y de las Indias, Islas y Tierra firme del mar Océano. Edición y Estudio preliminar de Carlos Seco Serrano, en «Biblioteca de Autores Españoles» 80, 81, 82, Madrid .1955-1956. - Cfr. J.A. LLORENTE, Defensa canónica y politica contra injustas acusaciones de fingidos crimenes, Paris: Imprenta de Plassan 1819 ( ?), p. 93, donde cita la Historia de Carlos V de Sandoval. - Asimismo JOANNIS GeNESII SEPUlVEDAE, De rebus gestis Caroli V, en ID., Opera, c., vols. I y II $^{\circ}$. - Tras la muerte de Llorente iban a aparecer historiadores franceses con un gran interés por la historia de España del siglo XVI. Louis-Prosper Gachard, Amédée Pichot y François-Auguste-Marie Mignet componen una tríada de gran brillantez. Pero éstos ya pertenecen a otra época.

${ }^{236}$ Iván NÚÑEZ DE LA PEÑA, Conquista y antigüedades de las Islas de la Gran Canaria, y su descripción, compuesto por el Licenciado Don ------, natural de la dicha Isla de Thenerife en la Ciudad de la Laguna. Con privilegio. En Madrid: en la Imprenta Real, 1676, 564 pp. Edición facsímil preparada por Jonathan Allen, precedida por un prólogo de Antonio Bethencourt Massieu y editada por Servicio de publicaciones. Universidad de Las Palmas de la Gran Canaria, 1994.

237 Benito Gerónimo FEIJÓO Y MONTENEGRO (1676-1764), Theatro crítico universal, o Discursos varios en todo género de materias para desengaño de errores comunes/ escrito por ------, Madrid: por D. Joachim de Ibarra... a costa de la Real Compañía de Impresores y Libreros, 1777. Nueva impresión, en la qual van puestas las adiciones del Suplemento en sus lugares. 8 vols in- $4^{\circ}$. - Está también la edición de Pamplona: en la Imprenta de Benito Cosculluela..., 1784-1785, nueva impresión en la 
44.- Douze volumes in quarto reliés en parchemin, en espagnol, Histoire littéraire

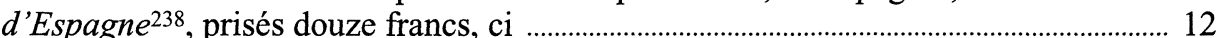

45.- Dix volumes in quarto, reliés en parchemin, en espagnol, dont Bibliothèque antique de l'Arragon ${ }^{239}$, prisés dix francs, ci ..................................................................... 10

46.- Seize volumes in douze et in dix huit dont Recherches sur les Américains ${ }^{240}$, ROBERTSON, Histoire d'Amerique ${ }^{241}$, prisés dix francs, ci ............................................. 10

qual van puestas las adiciones del Suplemento en sus lugares. 8 vols. in- $4^{\circ}$. - Y también, Demonstración crítico-apologética del Theatro crítico universal, que dio a luz el R.P.M.Fr. Benito Gerónimo FEIJÓO Y MONTENEGRO/ hácela uno de los aprobantes, el R. Fr. Martín Sarmiento, Madrid: Imprenta Real de la Gazeta 1779, 2 vols. in- $4^{\circ}$.

${ }^{238}$ Fr. Rafael y Fr. Pedro RodRíGuez MoHEdANO, Historia literaria de España, desde su primera población hasta nuestros días. Origen, progresos decadencia y restauración de la Literatura española en los tiempos primitivos de los Phenicios, de los Cartagineses, de los Romanos, de los Godos, de los Arabes, y de los Reyes Católicos, con las vidas de los hombres sabios de esta Nación, juicio crítico de sus obras, extractos y apologías de algunas de ellas: disertaciones históricas y críticas sobre varios puntos dudosos para desengaño e instrucción de la Juventud Española, Madrid, varias imprentas y años a partir de 1766.9 vols. in- $4^{\circ}$. Cfr. la importante recensión de SEMPERE Y GUARINOS, Biblioteca Española, c., IV, 66-72. -

${ }^{239}$ Félix DE LATASSA Y ORTÍN, Bibliotheca antigua de los escritores aragoneses que florecieron desde la venida de Christo hasta el año de 1500, Zaragoza: M. Heras, 1796, 2 vols. in- $4^{\circ}$. Seguidamente apareció ID., Bibliotheca nueva de los escritores aragoneses que florecieron desde el año de 1500 hasta 1802, Pamplona: J. de Domingo, 1798-1802, 5 vols. in- $4^{\circ}$. Finalmente, ID., Bibliotheca antigua y nueva de los escritores aragoneses, 1804-1806, 3 vols. en formato de 28 centímetros. «Del libro de Latassa apenas si se conserva en la estantería del erudito o en las bibliotecas públicas tal cual ejemplar, y, si por acaso ofrece algunos el comercio, solamente son asequibles para el desprendimiento del potentado o para la prodigalidad del bibliófilo, que, ante la realización de su apetito, no miden la enormidad del sacrificio. $\mathrm{Y}$ es que, con haberse hecho tirada numerosísima de la obra, los dos sitios que las tropas de Napoleón I pusieron a Zaragoza y la devastación de que entonces y después fueron objeto sus librerías, produjeron la extinción casi absoluta de la edición publicada.» Joaquín GIL BERGES, Prólogo (pp. XXI-XXII) a Miguel GÓMEZ URIEL, Bibliotecas antigua y nueva de escritores aragoneses de LATASSA, aumentadas y refundidas en forma de Diccionario bibliográfico-biográfico, 3 vols., Imp. de Calisto Ariño 1884-1886. - Cfr. ad illustrandum, Toribio DEL CAMPILLO Y CASAMOR, Indice alfabético de autores para facilitar el uso de las Bibliotecas antigua y nueva de los escritores aragoneses dadas a luz por el Dr. Latassa y Ortín, compuesto y publicado por ------, Madrid: Imp. de T. Fortanet, 1877, 263pp.

240 Cornelius PAUW (1739-1799), Recherches philosophiques sur les américains, ou Mémoires intéressants pour servir à l'Histoire de l'espèce humaine. - Avec une Dissertation sur l'Amérique et les américains par Don PERNETY, Londres 1771, 3 vols. - El tomo III recoge el documento impugnatorio de Don Pernety, que ya había sido publicado anteriormente - en 1770, en Berlín- y también la apología de Pauw frente a Pernety. - Hay edición facsímil de la de Berlín de 1774: Cornelius de Pauw, Recherches philosophiques sur les américains, ou Mémoires intéressants pour servir à l'Histoire de l'espèce humaine. Préface de Michèle DUCHET, Paris: J.M. Place, 1991, 2 vols. Además, en 1995 apareció la edición en soporte magnético que se puede consultar en «bnf.fr».

241 William ROBERTSON (1721-1793), History of America, W. Strahan, London 1777, 2 vols. in $4^{\circ}$.- ID., Histoire de l'Amérique, Panckoucke 1780, 4 vols. in- $12^{\circ}$ : la traducción era de Suard, cuñado del propio Panckoucke, ayudado por Morellet. Cfr. TUCOO-CHALA, c., 131-132.- Hay también traducción castellana; pero posterior a la época de Llorente. W. ROBERTSON, Historia de la América. Traducción hecha con todo esmero y exactitud y aumentada con los libros IX y X. Edición adornada con láminas. Librería de J. Oliveres y Gavarro, Barcelona 1840, 2 tomos.

Inquisidores contra la Inquisición

Hispania Sacra 55 (2003) 
47.- Six volumes in octavo, reliés, Itinéraire d'Espagne de $\operatorname{LABORDE}^{242}$, prisés quinze francs, ci

48.- Quinze volumes in octavo, reliés, dont Voyages en Espagne ${ }^{243}$ et dont $\left(\operatorname{sic}^{244}\right)$ Carlos $^{245}$, prisés douze francs, ci

49.- Douze volumes in octavo et in quarto reliés dont Voyages en Espagne par CLÉMENT ${ }^{246}$ et par SWINBURNE ${ }^{247}$, prisés douze francs, ci

242 Alexandre-Louis-Joseph, COMTE DE LABORDE (1778-1842), Histoire descriptif de l'Espagne, et tableau élémentaire des différentes branches de l'administration et de l'industrie de ce royaume, à Paris: chez H. Nicolle et Lenormant, 1808,6 vols. in- $8^{\circ}$., dont un atlas. - ID., Itinerario descriptivo de las provincias de España, y de sus islas y posesiones en el Mediterráneo; con una sucinta idea de su situación geográfica, población, historia civil y natural, agricultura, comercio, industria, hombres célebres.../ traducción libre del que publicó en francés Alexandro Laborde en 1809, Valencia en la Imprenta de Ildefonso Mompié, 1816, 2 vols in $4^{\circ}$. El segundo es de atlas.

243 ABBÉ PRÉVOST (Antoine François Prévost d'Exiles), Histoire générale des voyages ou Nouvelle collection de toutes les relations de voyages par mer et par terre, qui ont été publiées jusqu'à présent dans les différentes langues de toutes les nations connues, contenant ce qu'il y a de plus remarquable, de plus utile et de mieux avéré dans les pays où les voyageurs ont pénétré, touchant leur situation, leur étendue, leur limites ... avec les moeurs et les usages des habitants... pour former un système complet d'histoire et de géographie moderne, Chez Panckoucke 1769, 20 vols. in- $4^{\circ}$; et 68 vols. in-12 $2^{\circ}$. (Privilège 1769 renouvelé in 1776 pour une $2^{\mathrm{e}}$. rééd.). - En castellano: ID., Historia general de los viages, o nueva colección de todas las relaciones de los que se han hecho por mar y tierra, y se han publicado hasta ahora en diferentes lenguas de todas las naciones conocidas /Obra traducida del inglés al francés por... Antonio Francisco Prévost y al castellano por don Miguel Terracina. Madrid: en la Imprenta del Consejo de Indias 1764. - En realidad Prévost no fue un simple traductor, sino un compilador de criterio que influyó en la educación de los lectores franceses y contribuyó a implantar un estilo informativo sereno e ilustrado. - Una abreviación de la obra de Prévost, es la de M. DE LA HARPE, Abrégé de l'Histoire générale des Voyages contenant ce qu'il y a de plus remarquable, de plus utile et de mieux avéré dans les Pays où les voyageurs ont pénétré, à Paris: Hôtel de Thou, privilège 1780,23 vols. in $-8^{\circ}+$ un atlas in $-4^{\circ}$. - Cfr. et. las interesantes noticias sobre la relación de La Harpe con Voltaire, en S. TUCOO-CHALA, c., 155 y 272

244 El greffier interpretó dont en lugar de don.

245 César VICHARD, ABBÉ DE SAINT-REAL, Histoire de Don Carlos, fils de Philippe II, roi d'Espagne (par l'abbé de Saint-Real), Nouvelle édition, Amsterdam: G. Commelin, 1673, in-12 ${ }^{\circ}, 212$ .pp. Cfr. et. Friedrich SCHILLER (1759-1805), Don Carlos, tragédie traduite de l'allemand (Don Carlos, Infant von Spanien) par Adrien Lezay-Marnezia, Paris 1799 y 1808, in- $8^{\circ}, 392$ pp. Esta traducción ha sido siempre la más apreciada por su calidad y por las notas críticas y eruditas; aunque hace demasiadas concesiones al género romántico. Cfr. QUERARD, c.

246 Augustin-Jean-Jacques CLÉMENT (1717-1804), Journal de correspondances et voyages d'Italie et d'Espagne pour la paix de l'Eglise, en 1758, 1768 et 1769. Par M. Clément, alors Trésorier de l'église d'Auxerre, et depuis Evêque de Versailles, L.F. Longuet, Paris 1802 (an X), 3 vols in- $8^{\circ}$., 310 pp.,405, 287 pp. - Cfr. R. FoUlCHÉ-DELBOSC, Bibliographie des voyages en Espagne et en Portugal, Meridian Publishing co., Amsterdam 1969, $\mathrm{n}^{\circ}$ 173. - Sobre esta excelente recopilación bibliográfica conviene advertir que ya en 1896, el número 3 de la Revue Hispanique -dirigida por FOULCHÉ-DELBOSC-, estaba dedicado por entero a la Bibliographie des voyages en Espagne et Portugal. Reimpreso años después: Reprinted by Kraus Reprint Corporation, New York 1961. Ocho años más tarde apareció de nuevo como libro exento en la edición de Amsterdam.

${ }^{247}$ Henry SWINBURNE(1752-1803), Voyage de --- -- en Espagne en 1775 et 1776, traduit de l'anglois. El traductor es Jean-Benjamin de La Borde (1734-1794), Didot l'aîné, Paris 1787, in- $8^{\circ}$, XVI+535 pp. Cfr. FOULCHÉ-DELBOSC, $c$., nº 160. 
50.- Vingt volumes grand in $8^{\circ}$ reliés dont Histoire de la Culture d'Espagne ${ }^{248}$, en langue espagnole, prisés vingt cinq francs, ci

51.- Quinze volumes in 8 reliés dont Histoire de la guerre d'Espagne ${ }^{249}$, Eléments d'équitation espagnole ${ }^{250}$, en langue espagnole, prisés dix francs, ci ............................ 10

52.- Quinze volumes in quarto in octavo et in dix huit dont la Henriade ${ }^{251}$ en espagnol, la Jérusalem conquise $e^{252}$, prisés huit francs, ci ......................................................... 8

248 Juan Francisco MASDEU SJ, Storia critica di Spagna e della cultura Spagnuola in ogni genere, preceduta da un discorso preliminare. Opera di -----. In Fuligno: per Pompeo Campana, 1781, in-4 ${ }^{\circ}$. La obra, concebida para dar a conocer en Italia la cultura española, sólo publicó originalmente en aquella península los dos primeros tomos (el segundo en Firenze 1787). De la obra italiana decía Sempere y Guarinos: «El señor Abate Masdeu se adquirirá un nombre inmortal si la concluye, como puede esperarse de su talento y aplicación». J. SEMPERE Y GUARINOS, c., IV, Adición, in ipso fine. - El P. Masdeu publicó seguidamente toda su obra en España y adquirió con ella ilustre nombre y fama. Dejó inéditos otros cinco tomos además de los publicados. Juan Francisco MASDEU, Historia crítica de España y de la cultura española / obra de D. ------, Madrid: en la Imprenta de Sancha, 1783-1805, 20 vols. in-4․

249 Jean SARRAZIN (1770-1850 ?), Histoire de la guerre d'Espagne et de Portugal, de 1807 à 1814. Par ------. Ornée de la carte d'Espagne et de Portugal, où sont tracées las marches des armées française, anglaise et espagnole, dressée par M. Lapié ..., Paris: J.G. Dentu 1814, XVI + 404 pp., 21 $\mathrm{cm}$. - DESPACHO UNIVERSAL DE LA GUERRA. ESPAÑA, Histoire de la guerre d'Espagne contre Napoleon Buonaparte: tome premier / par une commission d'officiers de toutes armes établie à Madrid auprès de S. Ex. le Ministre de la Guerre; traduit de l'espagnol avec notes et éclaircissemens, par un témoin oculaire, à Paris: chez Le Normant, libraire; Nepveu, libraire; Delaunay, libraire...1818, xxxii +385 pp., $23 \mathrm{~cm}$. - LE GÉNÉRAL FOY, Histoire de la Guerre de la Péninsule sous Napoleon, précédée d'un tableau politique et militaire des puissances belligérantes. Publiés par la Comtesse Foy. Bruxelles: Chez J.-B. de Kock (s.a.), 1814 (fecha tomada de los preliminares), 4 vols., $15 \mathrm{~cm}$.

${ }^{250}$ Elementos de equitación militar para uso de la caballería española, Madrid: Imprenta Real, 1819,6 h. +224 pp. +12 lams, in- $4^{\circ}$. - Cfr. et. Francisco DE LAIGLESIA Y LARRAC, Ensayos sobre los verdaderos principios de la equitación, o teoría de la escuela de a caballo para el uso de los caballeros educandos del Real Seminario de Nobles. Por D. ------, Caballero de la Real y distinguida Orden española de Carlos III, Madrid, Imprenta Real, 1805, 1 h. +268 pp. +20 lams, in- $4^{\circ}$. - La referencia que hace el Inventaire apunta más bien al primero de los dos. - Cfr. Agustín PALAU CLAVERAS, Bibliografia hispánica de Veterinaria y Equitación anterior a 1901, Universidad Complutense. Facultad de Veterinaria, Madrid 1973, 57-58

${ }^{251}$ François-Marie Arouet de VOLTAIRE (el apellido Voltaire se lo añadió él mismo tomándolo del nombre de una pequeña posesión de la hacienda de su madre Marie Catherine Daumart, perteneciente a la nobleza del Poitou. Cfr. QUÉRARD, Voltaire, p. 276, nota 1. La Henriade es el más famoso poema épico compuesto por su autor. La primera edición se publicó bajo el título La ligue ou Henri le Grand, en Genève, Jean Mokpap 1723. Esta primera edición apresurada y notablemente imperfecta experimentó abundantes correcciones y salió luego bajo su definitivo título Henriade. Compuesta, en sus primeras ediciones, de 9 cantos experimentó abundantes y significativas añadiduras, correcciones y mejoras -la añadidura, incluso, de un nuevo canto entre el $\mathrm{V}$ y el VI-. La primera edición bajo el título Henriade es la de Londres de 1728. A partir de la edición de 1733 apenas hay ya variaciones y el texto permanece inalterado en su práctica totalidad. La animadversión anticatólica es patente desde el primer momento; pero el éxito de la Henriade, publicada y distribuida por cauce de suscripción fue clamoroso. La edición del 28 alcanzó la cifra de 150.000 suscriptores, suficiente para constituir desde entonces una de las primeras fuentes del caudal económico de Voltaire, que llegaría a ser cuantioso. Las ediciones de la Henriade en todos los idiomas se multiplicaron. El mérito literario es, a pesar de todo, cuestionable.

252 LOPE DE VEGA, Jerusalén conquistada, representada por primera vez en Madrid 1609, in-4 $4^{\circ}$.

Inquisidores contra la Inquisición

Hispania Sacra 55 (2003) 
53.- Vingt trois volumes in octavo en demi-reliures l'Art de vérifier les dates ${ }^{253}$, prisés quarante francs, ci ................................................................................................................ 40

54.- Dix volumes reliés in octavo dont Histoire des Cortes ${ }^{254}$ et Revolution de l'Amerique Espagnole ${ }^{255}$, prisés dix francs, ci

(suma total hasta aqui) 1251 francs (esta página recta del presente folio concluye con los «parafes» de validación) //

(suma total hasta aquí 1251 francs $^{256}$

55.- Dix volumes in octavo reliés dont Histoire d'Espagne par Adam D'EPPING $(\text { sic })^{257}$, prisés douze francs, ci

${ }^{253}$ L'Art de verifier les dates des faits historiques, des chartes, des chroniques et autres anciens monumens, nouvelle édition revue, corrigée et augmentée par un RELIGIEUX BÉNÉDICTIN DE LA CONGRÉGATION DE SAINT MAUR, à Paris: Chez G. Desprez, $1770,8+\mathrm{XX}+930 \mathrm{pp}$. - La obra fue puesta en el Índice Romano de 1826 a denuncia del Nuncio Giacomo Giustiniani, por el hispanismo regalista de muchas de sus páginas.

254 Juan SEMPERE Y GUARINOS, Histoire des Cortes d'Espagne, à Bordeaux: Chez Pre. Beaume, imprimeur libraire, $1815, \mathrm{XV}+415 \mathrm{pp} ., 22 \mathrm{~cm}$.

255 Considérations sur l'Amérique espagnole. Un appel à la vérité sur les causes ... de la révolution, par UN AMÉRICAIN, Paris 1817. - Esquisse de la révolution de l'Amérique espagnole. Traduit de l'anglais, Paris 1817, in- $8^{\circ}$. Cfr. http//catalogue2.bnf.fr . - Alvaro FLÓREZ ESTRADA (1766-1853), Examen imparcial de las disensiones de la América con la España, de los medios de su reconciliación $y$ de la prosperidad de todas las naciones, $2^{\mathrm{a}} \mathrm{imp}$. corregida y aumentada considerablemente por su mismo autor, Cádiz: Imprenta de don Manuel Ximénez Carreño, 1812, 283 pp., $22 \mathrm{~cm}$. - Cfr., reedición actual de ID., Examen imparcial de las disensiones de la América con la España, de los medios de su recíproco interés y de la utilidad de los aliados de la España, Concejo Municipal del Distrito Federal, Caracas 1974, 406 pp. - Miguel CABRERA DE NEVARES, Memoria sobre el estado actual de - las Américas y medio de pacificarlas, Madrid: Imprenta de José del Collado, 1821, (6) + 71 pp.

${ }^{256} \mathrm{La}$ suma total de las cantidades de este folio está equivocada. No es de 1251 francos sino de 1281 francos, salvo error en mi cálculo.

257 Georges-Bernard DEPPING, Histoire générale d'Espagne, depuis les temps les plus reculés jusqu'à la fin du XVIII Siècle, Paris: Colas, 18112 vols. in- $8^{\circ}$. El proyecto de Depping fue de 6 u 8 tomos. Pero, a punto de publicarse los dos primeros, Napoleón restableció la censura y Depping fue obligado a reimprimir 10 folios corregidos. Esto supuso una humillación desalentadora.- G.B. Depping nació en Münster (Westfalia), de padres alemanes el 11 de mayo de 1784 . A sus 19 años se traslada a París como turista; pero con tal fortuna que se quedó en Paris para siempre, aunque se naturalizó francés en 1827 -a sus 43 años-. Es el más famoso Depping - por no decir el único, si exceptuamos a su hijo Guillaume- de la literatura francesa de aquellos años. Verdadero polígrafo muy popular por su estilo algún tanto naïf, grato a los lectores de la época. El nombre Adam-que se lee en el inventaire- es probablemente su nombre alemán: no lo he podido comprobar. Cfr. Roman D'AMAT, G.B. Depping en ID. \& R. LIMOUZIN-LAMOTHE, Dictionnaire de biographie française, X, Letouzey et anê, Paris 1965, 1107-1108. 
56.- Vingt volumes in octavo, reliés, dont Histoire de Philippe deux par WALSTON $(\text { sic })^{258},{ }^{259} \mathrm{en}$ anglais, Histoire del 'Egypte par VOLNEY ${ }^{260}$ prisés vingt francs, ci ........ 20

57.- Douze volumes in quarto dont Histoire de la condamnation des templiers par DUPUY ${ }^{261}$ et Histoire de l'Empire Romain par LEBERGIER (sic) ${ }^{262}$ prisés douze francs, ci .... 12

58.- Quinze volumes in octavo, reliés, dont Révolution d'Espagne par LLOREN$\mathrm{TE}^{263}$, en espagnol, prisés dix huit francs, ci 18

59.- Dix neuf volumes in octavo et in douze, dont la Vie de Wasington (sic), en espagnol $^{264}$, prisés quinze frances, ci ....................................................................................... 15

60.- Dix neuf volumes in quarto dont Histoire de la litterature par ANDRÉS ${ }^{265}$ en espagnol prisés quinze francs, ci

258 Robert WATSON, The History of the Reign of Philip the Second, King of Spain, London 1777, 2 vols. - Hubo siete ediciones inglesas entre 1777 y 1812 así como otras en francés, alemán y holandés.

259 Tachada en este lugar la palabra histoire copiada por error.

260 Sobre Volney, cfr. supra item 16.

261 Pierre DUPUY (1582-1651), Histoire de la condamnation des Templiers, celle du schisme des papes tenants le siège en Avignon et quelques procès criminels ... - Édition nouvelle augmentée de l'Histoire des Templiers de Mr. GURTLER et de plusieurs autres pièces curieuses sur le même sujet, Bruxelles: F. Foppens, 1713, 2 vols.

${ }^{262} \mathrm{La}$ costumbre francesa de anteponer el artículo a los apellidos famosos pueden dar lugar a equívocos como el de copiar Lebergier por le Bergier. Nicolas BERGIER, Histoire des grands chemins de l'Empire Romain; contenant l'origine, progrès et étendue quasi incroyable des chemins militaires, pavez depuis la ville de Rome jusques aux extrémitez de son empire. Où se voit la grandeur et la puissance incomparable des Romains; ensemble l'éclaircissement de l'Itinéraire d'Antonin et la carte de Peutinger. Par ------. Nouvelle édition revue avec soin et enrichie des cartes et des figures, Bruxelles: J. Léonard, 1728, 2 vols., $29 \mathrm{~cm}$.

${ }^{263}$ Es el propio libro de Juan Antonio Llorente bajo el pseudónimo de JUAN NELLERTO, Memorias para la historia de la revolución española, con documentos justificativos, recogidas y compiladas por don ------, Paris: imprenta de M. Plassan, 1814-1816, 3 vols in- $8^{\circ}$. - Por esta misma época aparece un documento importante de José María Queipo de Llano y Ruiz de Saravia, COMTE DE TORENO, Aperçu des révolutions survenues dans le gouvernement d'Espagne, depuis le premier mpment de l'insurrection en 1808 jusqu'à la dissolution des Cortes ordinaires en 1814, traduit (par Charles Dunoyer) sur l'original écrit par un espagnol à Paris (le Comte de Toreno), Paris: Correard, 1820 (Le nomme de l'auteur sous la forme Torreno figure au titre de l'édition suivante, ainsi que le nomme du traducteur), in- $8^{\circ}$, II $+75 \mathrm{pp}$.

264 Vida de Jorge Washington... deducida de la que publicó en idioma inglés M. David RAMSEY, Paris: Imp. de Stahl, 1819, XII +216 pp in- $8^{\circ}$. -En inglés: D. RAMSEY, The life of George Washington, commander in chief of the armies of the United States in the War which established their independence; and First President of the United States, by D. Ramsey, M.D. of Charleston South Carolina, Member of Congress in 1782, 83, $84 \& 85$ and author of the History of the American Revolution, London: printed by L. Hanfard \& Sons, for T. Cadell and W. Davies, in the Strand: and Longman, Hurst, Rees, \& Orme, Paternoster Row, 1807, VIII +468 pp. $22 \mathrm{~cm}$.

265 Juan ANDRÉs (jesuita expulso), Dell'origine, progresso e stato attuale d'ogni letteratura, Parma: Stamperia Reale (Bodoni) 1782-1799. Los cuatro tomos, en cuarto mayor, proyectados por el autor se convirtieron en 7 vols. ya en su primera edición. Aumentaron, como suele suceder, en las siguientes ediciones. Su obra publicada primeramente en italiano, fue traducida al francés, inglés, alemán y castellano en los diez años siguientes a su primera publicación. Es el primer intento de gran porte de una historia literaria. Cfr. el artículo que se le dedica en J. SEMPERE Y GUARINOS, c., I, 100-112.

Inquisidores contra la Inquisición

Hispania Sacra 55 (2003) 
61.- Quatorze volumes in quarto reliés dont Révolution d'Espagne du PÉRE D'ORLEANS ${ }^{266}$ prisés cinq francs, ci ........................................................................................ 5 62.- Treize volumes in quarto reliés dont Histoire d'Espagne de FERRERAS ${ }^{267}$, et Dictionnaire français de FÉRAUD ${ }^{268}$ prisés vingt francs, ci .............................................. 20 63.- Neuf volumes in quarto reliés dont Théorie des Cortes $^{269}$, en espagnol, et Dictionnaire géographique de l'Espagne ${ }^{270}$, en espagnol, prisés douze francs, ci ............. 12

266 El padre jesuita Pierre Joseph D’Orléans (1641-1698), popularizado como LE PÈRE D'ORLÉANS, o -en castellano- el Padre d'Orleans. Escribe Histoire des révolutions d'Espagne, depuis la destruction de l'empire des Goths jusqu'à l'entière et parfaite réunion des royaumes de Castile et d'Aragon en une seule monarchie, continuée et publiée par les PP. Rouillé et Brunoy, $6^{\mathrm{e}}$ ed., 5 vols., Rollin Fils, Paris 1787.- Escribió también la Histoire des révolutions d'Angleterre: depuis le commencement de la monarchie, Chez Jean-Luc Nyon, Paris 1762. La edición de 1795 está continuada por H.F. Turpin, Chez Maradan, Paris, 5 tomos. -Asimismo la History of the Revolutions in England under the Family of the Stuarts from the year 1603 to 1690. In three books; wherein are contained many secret memoirs relating to that Family and the last great Revolution, anno 1698, E. Curll, London 1811. Traducida esta obra del francés, donde lleva una advertencia preliminar. De nuevo, el número de tomos referidos por el inventaire excede la proporción original de la obra -en este caso, de la obra de D'Orleans-. Y de nuevo, la advertencia de que tal vez bajo el mismo título inicial se albergan otras obras del propio D'Orleans. - A no ser que se tratase - es una posibilidad que no se puede descartarde varios ejemplares de la misma obra preparados para ser vendidos, habida cuenta de que el mercado de viejo estaba à l'ordre du jour. Se debe insistir, sin embargo, en que las páginas referentes a revoluciones, escritas por la pluma del Padre D'Orleans, dan para los tomos que refiere el inventaire y ello respondería a una costumbre conocida: la de señalar sumariamente una colección de escritos con el título del primero de ellos o del más relevante.

267 Juan de FERRERAS, Synopsis historica, chronologica de España, en Madrid: por F. de VillaDiego. Imprenta de F. de el Hierro, 1700-1727, 16 vols.in- $4^{\circ}$. A partir del tomo III comienza a titularse Historia de España. - «Quando me escribas algo de cosas públicas, sea siempre narración desnuda: el historiador debe ser impasible; imita la sequedad de Ferreras, no la filosofia de Tácito». Epistolario de LEANDRO FERNÁNDEZ DE MORATIN, edición, introducción y notas de René Andioc, Castalia, Madrid $1973,532$.

268 Jean-François FÉRAUD, Dictionnaire grammatical de la langue française. Nouvelle édition corrigée et considérablement augmentée, Paris:Vincent, 1768, 2 vols. - ID., Dictionnaire critique de la langue française, Marseille: J. Mossy père et fils, 1787-1788, 3 vols. in $4^{\circ}$.

269 Francisco MARTínEZ MARINA (1754-1833), Teoría de las Cortes o Grandes Juntas Nacionales de los Reinos de León y Castilla, monumentos de su constitución politica y de la soberanía del pueblo/ por el ciudadano ------, Madrid: Imprenta de don Fermín Villalpando, 1813, 3 vols, 1640 pp. en total.

270 REAl ACADEMIA DE LA HiSTORIA, Diccionario geográfico-histórico de España, Sección I, tomos I y II: Comprehende el Reyno de Navarra, Señorio de Vizcaya y provincias de Alava y Guipúzcoa, Madrid: en la Imprenta de la Viuda de don Joaquín Ibarra, 1802. - Cuarenta y cuatro años más tarde -Llorente era ya finado hacía 19 años- apareció la Sección II: Comprende la Rioja ó toda la provincia de Logroño y algunos pueblos de la de Burgos. Su autor el individuo del número, don Angel CASIMIRO DE GOVANTES, Madrid: Imprenta de los Sres. Viuda de Jordán e Hijos, 1846. - Cfr. sobre el Diccionario geográfico-histórico Antonio RUMEU DE ARMAS, La Real Academia de la Historia, Madrid: Real Academia de la Historia, 2001, 137. 
64.- Huit volumes in quarto, reliés, dont Histoire de la guerre en Flandre ${ }^{271}$ et Memories de l'Academie Royale ${ }^{272}$, en espagnol, prisés quinze francs, ci ..................... 15

65.- Douze volumes in quarto dont Généalogie de Grenade ${ }^{273}$, en espagnol et Trésor de la langue castellanne (sic) ${ }^{274}$ prisés quinze francs, ci ............................................ 15

66.- Onze volumes in quarto, dont Oeuvres de QUEVEDO, en espagnol, prisés douze francs, ci .

67.- Sept volumes in quarto, Analyse du Moniteur ${ }^{275}$, reliés, prisés quinze francs, ci

68.- Douze volumes in quarto dont Histoire des Templiers ${ }^{276}$ et Histoire de la maison de Bourbon ${ }^{277}$ prisés six francs, ci

271 Famiano STRADA SJ (1572-1649), Primera (y segunda) década de las guerras de Flandes, desde la muerte del Emperador Carlos $V$ hasta el principio del gobierno de Alexandro Farnese, tercero duque de Parma y Placencial escrita en latín por el P. Famiano Strada ... y traducida en romance por el P. Melchor de Novar ... corregida y enmendada por el Doctor de Bonne-Maison, en Colonia: (s.n.) 1682, sendos vols. in-folio, $30 \mathrm{~cm}$. - Cfr. et ID., De bello belgico, Antwerp 1648, (Lion rampant facing right). - Interesante, la noticia de The Newberry Library: Smith Center: Mapline 86/87 feature. «in 1632 Famiano Strada, a pro-Spanish Jesuit, incorporated the lion map into a two-volume History on the Netherlandish War of Independence». - ID., De bello belgico: The History of the LowCountrey Warres, translated into English by Sir Robert Stapylton, London 1650. - Cfr. Google.com

272 Memorias de la Real Academia de la Historia, Madrid, 14 tomos -el I en la Imprenta de Sancha1796-1903. «Tuvo como nota desfavorable esta colección la irregularidad cronológica, pues entre el tomo VI y el VII transcurrieron doce años de interrupción, entre éste y el VIII veinte y con respecto al IX veintisiete.- Desde el momento mismo de la erección de la Academia los primeros miembros resolvieron redactar disertaciones históricas, muchas de ellas leídas y discutidas en el seno de las juntas. Con objeto de dar permanencia y utilidad a estos trabajos se proyectaron las Memorias, cuyo tomo I apareció, como se ha dicho, en 1796. A poco que se hojeen los primeros volúmenes podrá comprobarse el prevalecimiento de pequeñas monografias sobre los más diversos temas. El espectro histórico aparece abordado en toda su amplitud, aunque de manera siempre dispersa. Tienen cabida en sus páginas desde la España primitiva hasta la más reciente. En cuanto a la temática, la variedad es inmensa, historia, política, social, económica, y cultural. Particular incidencia tienen la historia militar y eclesiástica, las instituciones, las leyes, las biografias de reyes y personajes. También la literatura y el arte. En algún caso esporádico las Memorias sirvieron para dar a conocer, en exclusividad, auténticos libros». A. RUMEU DE ARMAS, $c$., 170-172. - Está claro, por lo tanto, que Llorente sólo pudo conocer los siete primeros tomos.

273 Iván FLÓREZ DE OCÁRIZ, Libro primero y segundo de las Genealogías del Nuevo Reino de Granada. Recopilolo don ------, con privilegio, Madrid: Joseph Fernández de Buendía, Impressor de la Real Capilla de Su Magestad, año de 1674-1676.

${ }^{274}$ Sebastián de COVARRUBIAS OROSCO, Parte primera (y segunda) del Tesoro de la lengua cas tellana o española, compuesto por don ----- y añadido por Benito Remigio Noydens, Madrid: G. de León, 1673-1674, 2 tomos en 1 vol. in-folio.

275 Révolution française ou Analyse complète et impartiale du Moniteur, suivie d'une table alphabétique des personnes et des choses, Paris: Girardin (imp. de E. Charles) an. IX-X (1801-1802), 7 tomes en 6 vols. in $-4^{\circ}$.

276 Pierre DuPUY, Histoire de l'Ordre Militaire des Templiers ou chevaliers du Temple de Jesusalem dépuis son établissement jusqu'à sa décadence et sa suppression, par ------, Bruxelles: P. Foppens 1751, in- $4^{\circ}$.

277 J.-L. RIPAULT DÉSORMEAUX (1724-1793), Histoire de la maison de Bourbon (jusqu'en 1589), Imprimerie Royale, Paris 1777-1788, 5 vols. in $-4^{\circ}$. Cfr. QUÉRARD, $c$.

Inquisidores contra la Inquisición

Hispania Sacra 55 (2003) 
69.- Treize volumes in quarto, reliés, dont de la Monarchie d'Espagne ${ }^{278}$, en espagnol, Histoire de l'Inquisition en Espagne ${ }^{279}$, prisés neuf francs, ci .............................. 9

70.- Dix volumes in folio dont Histoire de Valence ${ }^{280}$ en espagnol, Histoire de Charles cinq ${ }^{281}$, aussi en espagnol, prisés dix francs, ci ................................................... 10

71.- Six volumes in quarto dont TACITE, en espagnol, et les Memoires de PHILIPPE DE COMMINES ${ }^{282}$, prisés six francs, ci

(Suma total hasta aquí) // 1478 francos

(Suma total hasta aquí) 1478 francos

278 José PELliCER DE OSSAU Y TOVAR, Annales de la Monarquía de España después de su pérdi$d a$, que escribió don ------, que consagra a Don Carlos II don ------, Madrid: F. Sanz, 1681, in-folio, 432 pp. - Cfr. et. Virgilio MALVEZZI, Sucesos principales de la Monarquía de España en el año de mil $i$ seiscientos y treinta $i$ nueve, escritos por el Marqués --.---, del Consejo de Guerra de Su Magestad. (En Colophon) En Madrid en la Emprenta Real, año de 1640.

279 Sin duda se trata de alguno o algunos de los auțores clásicos de la historia de la Inquisición, que Llorente cita en su Histoire critique de l'Inquisition d'Espagne, la cual fue escrita por él en su época de París.

280 Gaspar ESCOLANO, Década primera de la Historia de la insigne y coronada Ciudad y Reyno de Valencia, por el licenciado --.---, Rector de la Parrochia de Sant Esteuan, Coronista del Rey Nues tro Señor en el dicho Reyno y predicador de la Ciudad y Consejo. Primera Parte: Dirigida a los tres Estamentos, Eclesiástico, Militar y Real y, por ellos a los Diputados. Contiene esta Década curiosas generalidades de España y la Historia de Valencia hasta el Rey Don Pedro, hijo del Rey Don Jaime el Conquistador. Con una descripción del Reyno, historia de varios sucessos y relación de los linages y personas eminentes que en él han florecido, y las guerras de las Comunidades, que llamaron Germanía, sierra deEspadán y expulsión de los moriscos. - Segunda Parte: exactamente el mismo fontispicio que la Primera; tan sólo difiere el año de edición, que es el siguiente. Cada una de las partes se organiza en 5 libros. Valencia: Pedro Patricio Mey, junto a Sant Martin, 1610-1611, 2 vols. in-folio. A costa de la Diputación - Edición facsímil del Departamento de Historia Moderna. Universidad de Valencia, 1972, 10 vols. (cada uno de los vols. corresponde a un libro). - Conviene notar que el autor llama Década al espacio de diez años de trabajo e investigación. Había proyectado dedicar tres décadas a toda la historia. Pero no publicó más que la primera. Otros trabajos importantes de investigación y el mismo final de su vida se lo impidieron.

281 Cfr. supra item 41.

282 Les Mémoires de messire PHILIPPE DE COMMINES, chevalier, seigneur d'Argenton, sur les principaulx faicts \& gestes de Louis Onziesme \& de Charles Huictiesme son filx, roys de France: reveus et corrigez par Denis Sauvage de Fontenailles en Brie, sur un exemplaire pris à l'original de l'autheur \& suyvant les bons historiographes \& croniqueurs: avec distinction de livres selon les matières, estans aussi les chapitres autrement distinguez que par cy devant, \& le brief, le tout mieulx ordonné: ainsi que les lecteurs pourront veoir par l'advertissement à eulx adressé après l'Epistre au roy. Imprimé à Paris par Guillielme Morel, pour Galiot du Pré. On les vend à Paris par Galiot du Pré 1561. - El volumen va dividido en 8 libros. Hay también una vida del Arzobispo de Viena por cuyo consejo escribió esta obra Philippe de Commynes (cuya vida se extendió desde ca. 1447 hasta 1511 . La escritura de su apellido con $y$ es la más actual). -Cfr. et. PHILIPPE DE COMMINES, Memorias de ----- Señor de Argenton, de los hechos y empresas de Luis Undécimo y Carlos Octavo, reyes de Francia, desde el año 1464 hasta el año de 1468, traducidas del francés. Ilustrolas con sus escolios don Juan Vitriano. Nueva impresión corregida de muchas faltas y adornada con muchos retratos de los príncipes y de los personajes ilustres de los quales se haze mención en esta historia. Amberes, por H. y C. Verdussen, 1714, 2 vols., $33 \mathrm{~cm}$. 
72.- Douze volumes in folio dont Les Annales d'Espagne et de Portugal283, prisés quinze francs, ci

73.- Douze volumes in folio dont Histoire généalogique du PERE ANSELME ${ }^{284}$ et la Bibliothéque orientale d'HERBELOT ${ }^{285}$ prisés vingt (sic) francs, ci

74.- Sept volumes in quarto dont Dictionnaire de CALPIN ${ }^{286}$, prisés douze francs, ci

75.- (al margen izquierdo) Vingt deux volumes in folio petit et in quarto, contenant divers manuscrits dont Les animaux parlans $\left(\text { sic }^{287}\right)^{288}$; mélanges divers -en deux volumes-; variétés littéraires -trois volumes-, écrits en partie de la main de M. LLORENTE, prisés trente francs, ci

76.- Quatre volumes in folio dont Histoire des écrivains d'Espagne ${ }^{289}$, prisés six francs,

283 Juan AlVAREZ DE COLMENAR, Annales d'Espagne et de Portugal contenant tout ce que s'est passé de plus important dans ces deux royaumes \& dans les autres parties de l'Europe ... avec la description de tout ce qu'il y a de plus remarquable en Espagne \& en Portugal, Amsterdam: F. L'Honoré, 1741,8 vols.

284 P. de Guibours, dit le PÈrE ANSELME (Agustino descalzo nacido en París hacia 1625 y fallecido en 1694), Histoire généalogique et chronologique de la Maison Royale de France, des Pairs, des grands Officiers de la Couronne et de la Maison du Roy et des anciens Barons du Royaume, $3^{\mathrm{e}}$. éd., Amsterdam: chez les Fréres Chatelain, 1713. - La obra fue continuada por los padres Ange de SainteRosalie y Simplicien. Prueba de su interés es la edición facsímil de la de Paris, édition du Palais Royal, New York -London / Johnson Reprint Corporation, 1967, 9 vols.

285 Barthélemy D'HERBELOT (Paris 1625-1695), Bibliothèque Orientale ou Dictionnaire Universel contenant tout ce qui fait connaître les peuples de l'Orient, obra póstuma, Paris 1697, in-folio. Otras ediciones: La Haye: J. Neaulme \& N. Van Daalen, 1777-1779, 4 vols. - Paris: Montard, 17811783,6 vols.

286 Septem linguarum CALEPINUS, hoc est, lexicon latinum variarum linguarum interpretatione adjecta in usum Seminarii Patavini, Patavii: ex Typographia Seminarii: apud Joannem Manfré 1731, emendatior, 2 vols. in-folio. Expurgado por el Índice de 1790. - Se ha citado la edición de 1731 por ser próxima a Llorente y por ser también la más moderna. Ambrosio Calepino -o de Calepio- había nacido en Bérgamo en 1435 de la antigua e ilustre familia de los Condes de Calepio. Ingresó en la Orden Agustina y en ella perseveró hasta su muerte en 1511. La primera edición de su Diccionario es la de Reggio en 1502. Hubo luego numerosas ediciones, siempre reformadas -como tantas veces sucede con obras de este género-. Cfr. Antonio POSADA Y RUBín DE CELIS, Biografia eclesiástica completa, III, Madrid / Barcelona 1850, 197.

287 Por parlants.

288 «Durante mi residencia en aquella ciudad de Zaragoza, me divertí también en traducir del italiano al español el poema irónico del célebre abate Casti, intitulado Gli animali parlanti (Los animales parlantes). Es un tratado de política sobre las diferentes constituciones de los Estados, dividido en muchos cantos, bajo el velo de la fábula de los cuadrúpedos; el mérito relevante, que según mi opinión tiene aquel poema, excitó mis deseos de poseerlo en mi lengua nativa. Lo conservo inédito y sin darle la última mano». J.A. LLORENTE, Noticia biográfica, c., 122. - De la obra de Gianbattista Casti se hicieron por entonces dos ediciones: una en Paris, Treuttel, 1802; otra en Milano, Mainardi, 1801.

289 Podría tratarse de dos obras, a saber: Joseph RODRÍGUEZ DE CASTRO, Bibliotheca española: Tomo primero que contiene la noticia de los escritores rabinos españoles desde la época conocida de su literatura hasta el presente ( (34) +668 + (168) pp.). Tomo segundo que contiene la noticia de los escritores gentiles españoles y la de los christianos, hasta fines del siglo XIII de la Iglesia ( (8) + 748

Inquisidores contra la Inquisición Hispania Sacra 55 (2003) 
77.- (al margen izquierdo) Un lot de cartes géographiques prisés huit francs, ci ... 8

78.- Douze volumes in folio reliés dont Histoire d'Espagne ${ }^{290}$ prisés dix francs, ci

79.-Seize volumes in quarto dont Bibliothéque anciènne de l'espagnol291, en latin, prisés quinze francs, ci ........................................................................................................ 15

80.- Dix sept volumes grand in octavo Histoire d'Espagne de MARIANA ${ }^{292}$, en espagnol, prisés vingt cinq francs, ci ....................................................................................... 25

81.- Cinquante sept volumes, tant in folio, in octavo qu' in douze, dont Dictionnaire espagnol francais de TABOADA ${ }^{293}$, Histoire de Gil Blas ${ }^{294}$ en espagnol, Histoire de

pp.), Madrid: Imprenta Real de la Gaceta, 1781-1786, 2 vols. in-folio, $35 \mathrm{~cm}$. - Cfr. et. la edición facsímil de ed. G. Olms, Hildesheim / New York, 1977, 2 vols., $25 \mathrm{~cm}$. - Francisco Xavier LAMPILLAS (SJ), Ensayo histórico apologético de la literatura española contra las opiniones preocupadas de algunos escritores modernos italianos, traducido del italiano al español por Doña Josefa Amar y Borbón, $2^{a}$ edición corregida, enmendada e ilustrada con notas por la misma traductora. Indice alfabético de los principales autores y materias, Zaragoza: Oficinas de Blas Miedes 1783, 6 tomos en 3 vols. in- $4^{\circ}$. - Pero también -pese a que no se advierte que la obra esté en latín- podría muy probablemente ser la obra de Nicolás Antonio, Bibliotheca Nova sive Hispanorum Scriptorum qui ab anno MD ad MDCLXXXIV floruere, auctore Domino NICOLAO ANTONIO HISPALENSI I.C., Ordinis Sancti Jacobi equite, patriae Ecclesiae canonico, Regiorum Negotiorum in Urbe \& Romana Curia procuratore generali, Consiliario Regio. Nunc primum prodit, recognita, emendata, aucta ab ipso auctore, Matriti, Apud Viduam et Heredes D. Joachim Ibarrae Regii quondam Typographi, 1783-1788, 2 vols. in-folio, $37 \mathrm{~cm}$.

${ }^{290}$ La Historia General de España de MARIANA fue de tal popularidad que cabe pensar que ésta de que aquí se habla es un ejemplar de dicha obra -además del ejemplar que explícitamente se señala infra, item 80-.

291 NiCOLÁs ANTONIO. Bibliotheca Hispana Vetus, sive Hispani Scriptores qui ab Octaviani Augusti Aevo ad annum Christi MD floruerunt. Auctore NiCOLAO ANTONIO HISPALENSI I.C. ..., curante Francisco Perezio Bayerio, valentino Sereniss. Hisp. Infantum Caroli III Regis filiorum Institutore primario, Regiae Bibliothecae Palatino-Matritensis Praefecto, qui et Prologum \& Auctoris vitae epitomen \& notulas adiecit, libri decem, Matriti, apud Viduam et Heredes D. Joachim Ibarrae, Regii quondam Typographi, 1788. - Cfr. la edición facsímil -tanto de la Vetus como de la Nova Bibliotheca- de Visor, Madrid 1996. - Cfr et. la ed. facsímil de ambas bibliotecas de la Università di Torino. Torino: Bottega d'Erasmo, 1963, con Presentazione di Mario Ruffini. 3 vols. in-folio.

292 Juan de MARIANA SJ (1535-1624), Historia general de España, compuesta, enmendada y añadida por el P. ------, con el Sumario, Tablas y, también, con la Continuación que escribió en latín el P. Fr. Joseph Manuel Miniana ..., traducido nuevamente al castellano (Historiae de rebus Hispaniae) Madrid: B. Cano, 1794-1795, 10 vols.

${ }^{293}$ Melchior-Emmanuel NÚÑEZ DE TABOADA, Dictionaire français-espagnol, espagnol-français, plus complet et plus correct que tous ceux qui ont été publiés jusqu'à ce jour, y compris celui de Capmani. En Paris: chez Brunot-Labbé, 1812, 2 vols.

294 Alain René LeSAGE (o LE SAGE), Histoire de Gil Blas de Santillane ..., enrichie de figures, Paris: chez Pierre Ribou, Quay des Agustins à la descente du Pont Neuf à l'Image de saint-Louis, 1715. Avec aprobation etc..., 2 vols. in 12. Es la primera edición de esta célebre novela aparecida en tres fechas distintas y alejadas unas de otras. Existe algún tomo que lleva fecha de 1714: pero es un ejemplar muy raro. La edición de 1747 es importante por ser la última y porque contiene añadiduras y reformas del propio Lesage. En 1880 se presentaron tres ejemplares de tres tomos completos. Pero son raros, ya que ha sido habitual la edición de tomos separados. Cfr. Antonio PALAU Y DULCET, Manual del librero hispano-americano, c., VII, Palau, Barcelona 1954, 503 y ss. - El «Gil Blas» de Lesage 
Frederic deux ${ }^{295}$, prisés vingt francs, ci ..................................................................... 20

82.- Huit volumes in octavo reliés dont POTTER, Esprit de l'Eglise ${ }^{296}$, prisés dix huit francs, ci

83.- Treize volumes in octavo et in quarto, Origine des cultes ${ }^{297}$, prisés vingt francs, ci

84.- Douze volumes tant in quarto qu'in octavo dont POMPONIUS MELLA ${ }^{298} ; A b r e-$ gé des Cultes ${ }^{299}$, prisés dix francs, ci

está evidentemente inspirado en obras literarias españolas del Siglo de Oro. De aquí, la reivindicación que pronto se levantó: Aventuras de Gil Blas de Santillana, robadas a España y adoptadas en Francia por Monsieur Lesage, restituidas a su Patria y a su lengua nativa por un español zeloso, que no sufre se burlen de su nación. Con privilegio. Valencia: oficina de Don Benito Monfort, 1792, 3 vols. - Juan Antonio LLORENTE, Observaciones criticas sobre el romance de "Gil Blas de Santillana», en las cuales se hace ver que M. Le Sage lo desmembró de "El bachiller de Salamanca», entonces manuscrito español inédito; y se satisface a todos los argumentos contrarios publicados por el conde de Neufchâteau... Su autor don ------, Madrid: Imprenta de T. Albán y Compañía, 1822, 408 pp. in $16^{\circ}$. - Esta misma obra de Llorente se publica en francés también en 1822 , Paris: Moreau, VIII $+309 \mathrm{pp}$. en $8^{\circ}$.

295 J.-Ch. ThiÉBAult DE LAVEAUX, Vie de Fréderic II, roi de Prusse. Strasbourg:Treuttel 1788, 7 vols. In- $12^{\circ}$. Anota QUÉRARD, $c$., que los cuatro primeros volúmenes se titulan Vie de Frédéric II y los tres últimos Lettres sur la vie et regne de Frédéric II.

${ }^{296}$ Louis-Joseph-Antoine de POTTER, L'Esprit de l'Église, ou Considérations philosophiques et politiques sur l'histoire des conciles et des papes depuis Charlemagne jusqu'à nos jours, Paris: Parmentier, 1821, 6 vols. In- $8^{\circ}$. - Anteriormente había visto la luz Considérations sur l'histoire des principaux conciles, depuis les apôtres jusqu'au grand schisme d'Occident, sous l'empire de Charlemagne, Bruxelles: P.J. Demat, 1816, 2 vols. In- $8^{\circ}$, que luego aparece refundida bajo el título $L$ 'Esprit de l'Église..., citada.

${ }^{297}$ Charles-François DUPUIS (1742-1809, membre de l'Académie des inscriptions et belleslettres), L'Origine de tous les cultes, ou la Religion Universelle, Paris an. III (1796), 4 vols. in- $4^{\circ}$. Nouvelle édition avec une Notice par M. Auguis, Paris: Babeuf, 1822,7 vols. In- $8^{\circ}$ et atlas.

298 POMPONII MELAE (geógrafo latino de los tiempos de Claudio) de situ orbis libri III, cum not. liter. et indice copiosissimo. Accedunt SEXTI RUFI AVIENI descriptio orbis terrae et ora maritima: PRISCIANI Periegesis: RUTILII Itinerarium et VIBIUS SEQUESTER, Argentorati, Treuttel et Würtz, 1809. - Cfr. et. POMPONIUS MELA, traduit en français sur l'édition d'Abraham Gronovius, le texte vis-à-vis la traduction, avec des notes critiques, géographiques et historiques, qui ont pour objet de faciliter l'intelligence du texte et de justifier la traduction; de mettre en parallèle l'opinion des anciens sur les points de géographie, de chronologie et d'histoire, et de présenter un système de géographie comparée, par C.-P. FRADIN, Poitiers: Catineau / Paris: Ch.Pougens, 1804,3 vols. in- $8^{\circ}$. Esta traducción, que no fue muy apreciada durante años, iba a merecer, sin embargo, una segunda edición en 1827. cft. QUÉRARD, $c$.

${ }^{299}$ Charles-François DuPUIS, Abrégé de l'Origine de tous les cultes. Nouvelle édition, Paris: Delaunay, 1820, in $8^{\circ}$. - La primera edición había aparecido en 1796. Cfr. QUÉRARD, c. - El Grand Dictionnaire Universel de Larousse, testigo ajeno a toda sospecha, hace la siguiente recensión: «Le principal ouvrage de Dupuis est l'Origine de tous les cultes, ou Religion Universelle (1795, 3 vols. In$4^{\circ}$. \& atlas, ou 10 vols. In- $8^{\circ}$ ). «Il est peu de livres qui aient fait plus de bruit dans le monde. Confondant les traditions religieuses des peuples et les mythologies, l'auteur ne voit dans les divinités, qu'elles revêtent la forme d'un homme ou celle d'un animal, que la représentation symbolique des astres ou de la force de la nature. Les mystères du christianisme eux-mêmes ne sont que des allégories dans cet inmense et impitoyable paradoxe. La guerre déclarée aux croyances par les raissonneurs du

Inquisidores contra la Inquisición

Hispania Sacra 55 (2003) 
85.- Six volumes in octavo, reliés, dont Les animaux parlans de CASTI ${ }^{300}$ et les Nouvelles ${ }^{301}$, en italien, prisés dix francs, ci ..................................................................... 10

86.- Neuf volumes in octavo, Ideologie de TRESSY (sic) ${ }^{302}$, prisés neuf francs, ci ......... 9 87.- Dix neuf volumes in octavo, reliés, Le Censeur ${ }^{303}$, prisés vingt francs, ci ..... 20 88.- Vingt cinq volumes in octavo, Dictionnaire historique description de l'Europe ${ }^{304}$, prisés cinquante francs, ci

$\mathrm{XVIII}^{\mathrm{e}}$ Siècle était continuée par Dupuis avec l'arme de l'érudition; mais il avait manqué son but: 1'Origine des cultes, exposition diffuse, sèche, hérissée de détails scientifiques, ne trouvait pas un seul lecteur dans le peuple. En 1796, il en fit un Abrégé plus clair, plus condensé, plus vigoureux, et qui fut mieux accueilli. Cet Abregé devint, sous la Restauration, avec les Ruines de Volney, un des principaux livres de la propagande antireligieuse. Depuis cette époque il est tombé dans l'oubli: il restera néanmoins comme le monument plus audacieux élevé par l'érudition à l'incredulité». Voz Dupuis (Charles-François).

300 Cfr. supra item 75. - Giambattista CASTI, Gli animali parlanti, poema epico... di --.--.. Aggiuntivi in fine 4 Apologhi del medesimo autore, Filadelfia 1801, 3 tomes en 1 vol. in $12^{\circ}$.- Otra edición casi contemporánea: la de Parigi, Treuttel e Wurtz, anno X (1802) 3 vols. in- $8^{\circ}$.

301 Giambattista CASTI, Novelle, Parigi: Stamp italiana, anno XII (1804) 3 vols. in- $8^{\circ}$. Las Novelle galanti de Casti pueden contarse entre las obras italianas de corriente libertina.

302 Le Comte Antoine-Louis DESTUTT DE TRACY (Pair de France et Membre de l'Académie française), Eléments d'Ideologie, nouvelle édition, Paris: chez Bachelier, 1817-1818, 5 parties en 4 vols. in $-8^{\circ}$.

303 Más que de $E l$ Censor, periódico madrileño bien conocido, que salía desde el año 1781 algunos de cuyos números fueron condenados y otros expurgados por la Inquisición en su edicto de 28 de febrero de 1789-, podría tratarse de Le Censeur European, fundado el 12 de junio de 1814, que reflejaba el ambiente político y social que Llorente iba viviendo día a día. Cfr. Grand Dictionnaire Universel de Larousse, Le Censeur, 708-709.

${ }^{304}$ No he encontrado ningún diccionario que coincida con ese título. La obra, sin embargo, se mueve en el caudal de interés progresivo que Europa ha merecido en el ámbito ilustrado. Por ejemplo la obra de Samuel Freiherr von PUFENDORF (1632-1694), An Introduction to the History of the principal Kingdoms and States of Europe. Made in English from the original High Dutch, $8^{\mathrm{a}}$ ed. cor. \& improved, London, Printed for B. Took 1719, 646 pp. Esta obra del bien conocido filósofo del Derecho Natural tuvo un importante eco y continuación en el ámbito historiográfico. Baste citar a Jodocus CRULL, A supplement to Mr. Samuel Pufendorf's Introduction to the History of Europe: containing a succinct, but most exact historical account of several European States \& countries not inserted in the said Introduction. London: Printed and sold by W. Taylor 1710, XIV +688 pp. $-\mathrm{O}$ también a Antoine Augustine BRUZEN DE LA MARTINIÈRE, Introduction à l'histoire moderne, générale et politique de l'Univers: où l'on voit l'origine, les révolutions \& la situation présente des différents Etats de l'Europe, de l'Asie, de l'Afrique \& de l'Amérique: commencée par le Baron de Pufendorf, augm. par A.A. Bruzen de La Martinière. Nouvelle édition revue et considérablement augmentée, corrigée sur les meilleurs auteurs \& continuée jusqu'en 1750, par M. DE GRACE. À Paris: chez Merigot 17531759,8 vols. - Pero el interés universal no se contrae a los continuadores de Pufendorf. Cfr. v.g.: Jean HINSELIN DE MORACHES, Portrait géographique et historique de l'Europe, Paris 1675, 3 parties en 4 vols. - LEUTHOFF DE FRANCKENBERG, Descriptio Statuum omnium Europae, Leipzig 1705, in-folio. -Jean-Baptiste Bourguignon D'ANVILLE, Etats formés en Europe après la chute del'Empire Romain en Occident, Paris: Imprimerie Royale 1771, 269 pp. in $-4^{\circ}$. - «En los siglos XVIII y XIX, como dice López Palomeque, el mundo conoce un proceso de europeización, de dominio y progreso de Europa, que da paso a una colonización en todos los órdenes y también en lo cultural: Europa se extiende por casi todo el mundo, y lo europeo es sinónimo de civilización, de modernidad, de progreso y de superioridad (la civilización europea como el punto más alto del progreso humano). En el siglo XVIII, 
Dans une autre pièce étant ensuite de la précedente egalement ci-dessus designée $e^{305}$.

89.- Onze volumes manuscrits ${ }^{306}$ in folio, Histoire generale de la Junta de Comuneros ${ }^{307}$ et des Mines ${ }^{308}$, prisés vingt francs, ci

Montesquieu manda dibujar un mapa de Europa y lo hace terminar en el Volga. Durante ese tiempo, el cosaco Yermak había iniciado hacía mucho la conquista de Siberia franqueando los Urales. Progresivamente se admitirá otorgar a esa línea de relieve -los Urales- la función límite, que autentifica hoy, en el kilómetro 1.777 del Transiberiano, el obelisco que marca con dos inscripciones flechadas, hacia el este la dirección de Asia, hacia el oeste la dirección de Europa. Esta formalización de los límites también se observa en otra discutida zona de transición: en Estambul, en la orilla del Bósforo, frente a la parte principal de la ciudad, existen unos indicadores flechados que señalan la dirección de Europa -hacia el núcleo principal de la ciudad de Estambul en 'lado' europeo- y hacia Asia, que corresponde al interior del territorio». F. LÓPEZ PALOMEQUE (coor.) ET ALII, Geografia de Europa, Ariel, Barcelona 2000, 32. - Otra obra de diversa índole, que coincide en tener naturaleza de «diccionario histórico y descriptivo de ámbito europeo", , es la de Carlos Antonio DE LA SERNA SANTANDER, Dictionnaire bibliographique choisi du quinzième siècle ou Description par ordre alphabétique des éditions les plus rares et les plus recherchées du quinzième siècle; précédé d'un Essai historique sur l'origine de l'imprimerie, ainsi que sur l'histoire de son établisement dans les villes, bourgs, monastères et autres endroits de l'Europe: avec la notice des imprimeurs qui y ont exercé cet art jusqu'à l'an 1500. À Bruxelles: Imprimerie de J. Tarte 1805-1807, 3 vols. $25 \mathrm{~cm}$.

305 En el inventaire no van subrayadas en modo alguno las palabras en negrita

306 Sobre los manuscritos de Llorente, cfr. Noticia biográfica, c., 121-123 y 133-136.

${ }^{307}$ El título de los manuscritos consignados en este item 89 es incitante sin duda alguna. Es cierto que Llorente ha prestado atención a Carlos I y a Felipe II, seguramente por su conexión con el gran asunto inquisitorial. Pero no parece que el eclesiástico riojano se sintiese atraído por la historia de la Santa Junta de los comuneros de Castilla, a no ser que le interesara en razón de su nueva sensibilidad como conspirador. En tal caso, lo más probable es que este item se refiera derechamente a la secta de los Comuneros: «Habiendo sido proclamada la Constitución, el Gobierno organizado según sus bases fue enteramente entregado a los Masones; ocuparon éstos todos los empleos, llegando a ser la España para ellos una provincia conquistada; pero la repartición de frutos de una victoria común no se hizo sin chocar infinitas ambiciones. Las rivalidades personales trajeron consigo contiendas muy serias entre sus individuos, extendiéndose a fragmentos de la Sociedad, que bajo el influjo de algunos que los acompañaron se separaron de la Sociedad madre para elevar otro nuevo poder entre las manos de una secta nueva. - Los miembros de ésta tomaron el nombre de Comuneros. Este nombre traía a la memoria antiguos recuerdos de una lucha armada que, por la defensa de algunos derechos populares, había osado atacar el poder de Carlos V. Esta simple denominación acompañó con algunos prestigios a la naciente unión, a la que acudieron de todas partes y, por otro lado, los adeptos no siendo nada escrupulosos en la admisión de los profanos, en poco tiempo tuvo un engrandecimiento considerable. (...) - Las logias o reuniones de la nueva sociedad, conocidas con el nombre de Torres, reconocían en cada provincia la autoridad de una Junta presidida por un jefe que tenía el título de Gran Castellano.La secta de los Comuneros fue establecida en Cataluña por Salvato, después vicepresidente de Cortes; Gironella fue el Gran Castellano de la provincia». Noticia acerca de las sociedades secretas organizadas en España hasta el año de 1823 y sobre las de Cataluña en particular. Archivo General de Palacio, Papeles de Fernando VII, tomo XVIII. Citado por Iris M. ZAVALA, c., 221-222.

${ }^{308}$ Los Minas son los dos guerrilleros navarros de la guerra de la Independencia Francisco Espoz y su sobrino Javier Mina, famosísimos jefes de partidas antifrancesas que, luego, desilusionados por la actitud y conducta de Fernando VII se deslizan hacia el constitucionalismo, el liberalismo y, en fin, el

Inquisidores contra la Inquisición

Hispania Sacra 55 (2003) 
90.- Vingt neuf volumes in octavo et in dix huit dont Métamorphoses D'OvIDE, TERENCE, CATULLE, CLAUDIEN ${ }^{309}$, latin et italien, prisés douze francs, ci .................... 12

91.- Dix sept volumes dont Histoire des Celestins ${ }^{310}$, prisés deux francs, ci .............. 2 92.- Quinze volumes in octavo et in douze dont Histoire de la maison de Sade ${ }^{311}$, prisés deux francs, ci ................................................................................................................. 2

ultraliberalismo radical, activista y conspirador. Ellos dos, y también sus secuaces: que comienzan a conspirar en Francia a partir de la fracasada rebelión de septiembre del año 14. Sobre las muy probables relaciones de Llorente con la conspiración de los Minas en Francia y en Cataluña, cfr. G. DUFOUR, Llorente en France, c., 288-289. - Sobre los Minas cfr. los dos tomos clásicos de José María IRIBARREN, Espoz y Mina el guerrillero, y Espoz y Mina, el liberal, Aguilar, «Evocaciones y memorias», Madrid 1965 y 1967. -Cfr. et. Manuel ORTUÑo MARTíNEZ, Xavier Mina, guerrillero, liberal, insurgente. Ensayo bio-bibliográfico, Universidad Pública de Navarra, Pamplona 2000.

${ }^{309}$ Aunque sea una edición de Claudianus que Llorente no pudo usar, la traigo a colación, habida cuenta de que es un autor poco conocido para los no especialistas en latinidad. CLAUDII CLAUDIANI Carmina / recensuit Theodorus Birt, Berolini: apud Weidmannos, 1892. En Monumenta Germaniae Historica, «Auctorum antiquissimorum» tomus 10.

310 Louys BEURRIER, Histoire du monastère et couvent des pères Célestins de Paris, contenant les antiquités et privilèges ensemble, les tombeaux et épitaphes des rois, des ducs d'Orleans et autres illustres personnes avec le testament de Louys, duc d'Orleans par le Père ---.--, Paris: Chez la Veuve de Pierre Chevalier, 1634 , in- $4^{\circ}, 429 \mathrm{pp}$.

311 Maurice Lever, en su biografia del Marqués de Sade, cuenta cómo el tío sacerdote -JacquesFrançois- Paul-Aldonse abbé de Sade-, que a la sazón vivía en Saumane, fue encargado de introducir a su pequeño -y ya singular- sobrino Donatian en la atmósfera del más incitante humanismo ilustrado. Así pues le recibió en el solar de Saumane donde el sacerdote, tras brillante y turbulento curriculum, vivía ya entregado a sus aficiones librescas y archivísticas. El culto sacerdote tenía por entonces cuarenta años y pico. Llevaba mucho tiempo trabajando en la biografía y contexto histórico del Petrarca y, también, en el amplio mundo de los trovadores y poetas del Medievo. Se ocupaba asimismo porque era apasionado genealogista- en todo lo referente a la historia familiar de los Sade. «Fue en el gabinete del abate donde Donatian comenzó su estudio de humanidades bajo la guía de su tutor. Conocía tan bien todo el plano de aquella biblioteca que era capaz de colocar a ciegas en su sitio y anaquel cualquiera de los libros. Su mano se dirigía sin error al lugar donde se hallaban los seis grandes volúmenes que componían el cartulario de Sade, y que contenían en orden cronológico, paso a paso, la historia completa de sus antepasados -desde el siglo XIII hasta su propio momento histórico- juntamente con la copia de los documentos legales: contratos, matrimonios, recibos, títulos honoríficos, profusión de diplomas, ejecutorias finamente caligrafiadas sobre amarillentas hojas de vitela». Pero este cartulario fue destruido en el saqueo del château de Mazan durante la Revolución. Menos mal que el abate había copiado un regesto del material en él contenido, que se conserva en el archivo de la familia de Sade. Una nota manual del propio Marqués de Sade -firmada el 26 de julio de 1797-afirma que todo el rico material archivístico fue transportado en los años 89, 90, 91 etc. al château de Mazan a requerimiento de Pelagie de Montreuil, esposa de Louis Aldonze Donatien de Sade, y que se hizo todo lo posible por conservarlo. Llegados tiempos más serenos el Marqués de Sade vino a Provenza y trasladó allí cuanto pudo recobrar de la anterior riqueza: lo conservó en cajones con ánimo de poner en orden las cosas cuando llegase la ocasión. Cfr. Maurice LEVER, Marquis de Sade. A biography, traducida del francés al inglés, Harper Collins publishers, London 1993, 56-57 y 575. - La obra original es: Maurice LEVER, Donatien Alphonse François, Marquis de Sade, Librairie Arthème Fayard 1991. La obra francesa es mucho más amplia que su traducción inglesa; pero Lever -una vez examinada esta versión- la reconoce como enteramente suya y reclama para sí los principales derechos de 
93.- Vingt cinq volumes necessitant description ${ }^{312}$, prisés deux francs, ci ................. 2 94.- Dix neuf volumes in octavo, in douze et in dix huit, reliés en parchemin, dont MARTIAL et HORACE prisés cinq francs, ci .................................................................................. 5 95.- Vingt volumes in douze dont Quid et quae ${ }^{313}$, prisés deux francs, ci .................. 2 96.= Vingt sept volumes dont Essais sur les moeurs par VOLTAIRE ${ }^{314}$, prisés quatre francs, ci

(Suma total hasta aquí)

(siguen los «paraphes» de validación en esta página recta del folio) /I

(Suma total hasta aqui) 1751 francos

97.- Trente huit volumes in douze dont MAXIME DE TYR ${ }^{315}$ et Fables de LAFONTAINE prisés quatre francs, ci

98.- Trente neuf volumes dont Proverbes divertissans ${ }^{316}$ prisés deux francs, ci ...... 2

autor. - Recientemente también M. LEVER ha iniciado la «Bibliothèque Sade» cuyo primer título es Papiers de famille en 2 tomos. I: Le règne du père, 1721-1760, Fayard, Paris 1993, 898 pp., $24 \mathrm{~cm}$. II: Le Marquis de Sade et les siens. 1761-1815, Fayard, Paris 1995, 761 pp., 24 cm. - Es muy posible que hubiesen podido llegar hasta Llorente documentos que procedían del saqueo del château de Mazan. En cualquier caso todo se volvió a vender.

312 Es decir, no identificables por el notario.

313 Quid et quae, si he interpretado bien el ductus de la mano del escribiente, que corrige sobre lo escrito. - No he visto obra alguna que lleve este título. Sí he visto obras de aquella época o algo posteriores con título estructuralmente construido sobre el quid y el quae, que delatan un origen de dialéctica escolástica. Por ejemplo: Herman, Schultz (de Louvain), Ad quaestionem? De jure feminarum romanarum defuncto succedendi ab intestato et ex testamento historice ita agatur ut appareat quid diverso tempore in hoc capite juris placuerit, et quae exstiterint causae illius mutati ? Responsio quae praemium portabit. Trajecti ad Rhenum: apud J. Altheer 1826, in- $8^{\circ}$., 140 pp. Cfr. «Annales Accademiae Rheno-Trajectinae», 1824-1825. - Saint-René Taillandier, René-Gaspard-Ernest Taillandier, De summa Providentia res humanas administrante quid senserint priores Ecclesiae scriptores et quae fuerit apud eos huius doctrinae fortuna et incrementum, Dissertatio Accademica. Scripsit S.-R. Taillander. Paris: e typis Crapelet 1843 , in- $8^{\circ}, 63$ pp.

${ }^{314}$ François-Marie Arouet de VOLTAIRE, Essai sur les moeurs et l'esprit des nations et sur les principaux faits de l'histoire d'puis Charlemagne jusqu'à Louis XIII. Genève 1775, 6 vols. in- $8^{\circ}$; Paris 1796,5 vols. in- $8^{\circ}$. - «Nouvelle édition sous un nouveau titre -anota Quérard-, mais refondue de l'Essai sur l'Histoire Universelle 1754-1758, 6 vols in-12'; et de l'Essai sur l'Histoire générale, (introducida en el Indice, diciembre de 1766) 1761-1763, 8 vols. in- $8^{\circ}$.

315 MAXIMI TYRII (autor pagano del siglo II, filósofo neoplatónico o, mejor, ecléctico. Se le encuentra en Roma en tiempos de Cómodo)... Sermones siue Disputationes XLI/ Ex Cosmi Paccii Archiepiscopi Florentini interpretatione ... ab Henrico Stephano ...emendata. Parisiis: ex Officina Henrici Stephani ... 1557. - MAXIMI TYRII, Dissertationes philosophicae / cum interpretatione Danielis Heinsii hac secunda editione emendatioribus. Accessit ALCINOI in Platonem introductio, Lugduni Batavorum: apud Joannem Patium, juratum et ordinarium Accademiae Typographum, 1614 (texto griego y latino). - Cfr. et. las Adnotationes in Maximum Tyrium de J. MARKLAND, en la $2^{\mathrm{a}}$ ed. de las Dissertationes por J. Davis, Londres 1740.

316 Llorente cita en sus páginas varias colecciones de proverbios, v.g.: Apothegmata de Conrado Licosthene (Cfr. Defensa canónica y política de don JUAN ANTONIO LLORENTE contra injustas acusaciones de fingidos crimenes, Paris: Imprenta de Plassan, 1816, 6), Apothegmas de griegos, romanos y otras naciones. (Ibidem, 57. «No puedo designar el autor -dice- porque el libro (preciosísimo en su 
99.- Vingt cinq volumes in douze et in dix huit dont LACTANCE prisés deux francs, ci

100.- Dix sept volumes in folio dont Cérémonies religieuses ${ }^{317}$, Liberté de

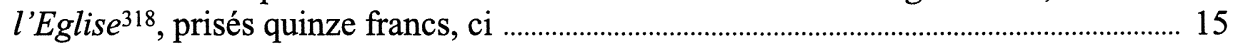

contenido) que por acaso he adquirido en París en lengua española carece de las primeras hojas y de las últimas. Es lástima no tenerlo entero porque merece reimprimirse en buena letra: la suya es del gusto que llamamos gótico.» - Compilación antigua española de Apothegmas (Ibidem 79). - Alciato, Emblemas (Ibidem 81) - Claudio Minoense, Commentarios de los emblemas de Alciato: impresión de París, en la imprenta de Jerónimo de Marnef, año de 1583 (Ibidem, 81-82).- Plutarco: Apothegmas lacónicos (Ibidem, 121). - Valerio Máximo, Factorum et dictorum memorabilium (Ibidem, 160). - Y, por supuesto, el libro bíblico de los Proverbios (Ibidem, passim). - Igualmente valoraba autores que contaban anécdotas de respuestas brillantes, de estratagemas novedosos, o de sucesos al borde de lo inverosímil. Por ejemplo el libro del napolitano Alexander AB ALEXANDRO, Dierum genialium. Alexander ab Alexandro es un jurista napolitano muerto en 1523. Publicó un estudio sobre la Ley de las XII tablas. Pero el libro que ha merecido multitud de ediciones -famoso por su erudición y por sus datos, por sus adiciones, enmiendas y por el afán de recuperar su primer atractivo- ha sido el Genialium dierum libri sex. Veneunt Parisiis: apud Joannem e Roigny, via ad Diuum Jacobum sub Basilisco et quattuor elementis, anno 1539. - Cfr. et. la edición de Frankfurt: ex officina typographica Nicolai Bassaei 1594, 2 vols. Y otras numerosas, como ya se ha dicho. - Para calibrar su talante napolitano, cfr. ALEXANDRI JURISCONSULTI NEAPOLITANI Dissertationes quattuor de rebus admirandis quae in Italia nuper contigere; id est: De somniis quae a viris spectatae fidei prodita sunt, inibique de laudibus Juniani Maii, maximi somniorum conjectoris. De umbrarum figuris et falsis imaginibus. De illusionibus: de illusionibus malorum daemonum, qui diversis imaginibus homines delusere. De quibusdam aedibus, quae Romae infames sunt of frequentissimos lemures et terrificas imagines quas auctor ipse singulis fere noctibus in urbe expertus est. S.d., s.a. Reeditada en version informática CDROM de la BNF 1995.

317 Antoine Augustin BRUZEN DE LA MARTINIĖRE (1662-1746), Cérémonies et coutumes religieuses de tous les peuples, par des figures dessinées et gravées par Bernard Picart (1673-1733), Amsterdam 1723. «En esta obra -como se lee en el Dictionnaire Universel de Larousse- curiosa por más de un título, el autor ha reunido todo lo que se sabía sobre las costumbres y las ceremonias religiosas de los diversos pueblos; ha indagado en los relatos de los más lejanos viajeros y ha descrito lo que, según ellos, ocurre en el interior de los templos de los países visitados, así como el ritual que acompaña los nacimientos, los matrimonios, la muerte en los diversos lugares del mundo. La más importante atención es para los judíos, los protestantes y los católicos, puesto que son los más conocidos. Pero también se presta el merecido tratamiento a otros muchos grandes pueblos de la tierra». El libro brinda la clave interpretativa, a saber: el miedo creó los dioses y los errores del hombre angustiado se han repetido por doquier hasta que el despertar a las Luces ha hecho remitir los temores oscurantistas. «Gracias a Dios - concluye el Larousse- se ha hecho la claridad sobre tan profundas tinieblas y el clero mismo -o su porción más ilustrada, por lo menos- no explota ya la credulidad pública más que en cuanto es necesario para evitar la contraposición abierta con sus predecesores». Sic. El juicio del Dictionnaire Universel es toda una indicación sobre el sentido y propósito de la obra. En las repetidas ediciones que siguieron, fue cobrando protagonismo y magnitud el cúmulo de grabados de Picart hasta tal punto que Bruzen de la Martinière apenas es recordado como autor del texto. La edición de 1783, puesta en el Índice por decreto de mayo de ese mismo año, salió ya en 9 volúmenes y la autoría se atribuye a una Société de gens de Lettres. El propio librero Jean Frédéric Bernard (fallecido en 1752) se sube también -en varias ediciones- al carro de la gloria con honores de autoría.

$318 \mathrm{La}$ obra más próxima a este título es la que aparece en el Índice de 1790: Pro libertate Ecclesiae gallicanae adversus Romanam aulam defensio Parisiensis Curiae. Ludovico v, Gallorum Regi, 
101.- Quatre volumes in folio dont SÉNĖQUE, en latin, prisés quatre francs, ci ....... 4

102.- Sept volumes in folio dont BAYLE ${ }^{319}$ prisés dix francs, ci ............................... 10

oblatum. Extat cum Tractatu DUARENI, De sacris Ecclesiae ministeriis. - Y la siguiente del mismo Índice de 1790: De libertate Ecclesiae gallicanae, libelli duo incerti Auctoris inserti Operibus PETRI PITHEI. - Puede decirse que en el origen de esta obra está Pierre PITHOU -nacido en Troyes el 1 de noviembre de 1539 y fallecido en Nogent-sur-Seine el 1 de noviembre de 1596-. Su libro Les libertés de l'Église gallicane se editó por primera vez en París: chez Mamert Patisson, 1594, 27 de julio, in- $8^{\circ}$. La saga de tratados que se publican al rebufo de Pithou son siempre importantes o, al menos, resonantes. En 1758 vio la luz como obra póstuma la de César CHESNEAU DU MARSAIS -nacido en Marseille el 17 de julio de 1676 y muerto el 11 de junio de 1756-, Exposition de la doctrine de l'Église gallicane par rapport aux prétentions de la cour de Rome, Genève: Par Cerfvol, en-12 ${ }^{\circ}$. En 1817 volvió a publicarse la Exposition de DU MARSAIS juntamente con Les Libertés de l'Église gallicane de PITHOU precedida de un Discours préliminaire de ClAVIER. Paris: Duponcet-Delaunay, 1817. - Pero es de muy particular interés la obra del propio Pierre PITHOU, Traitez des droits et des libertez de l'Église gallicane, sans lieu d'imprimerie 1731, 2 vols. in-folio. Esta obra -evidentemente póstuma y que presenta problemas acerca de su áutoría- había tenido ya su primera edición en 1639, edición que fue recogida y destruida. Mejor fortuna tuvo la segunda edición -1651-, que vio la luz con el sello de la Autoridad y luego fue la base de la Déclaration du Clergé de 1682.

319 Seguramente se trata de Pierre BAYLE, Dictionnaire historique et critique, cuya primera edición es de 1696 con 2 vols., in-folio. - La más antigua de la que hay edición facsímil es la cinquième édition avec la vie de l'auteur par M. de Maizeaux, Amsterdam 1740. Avec Privilège, 4 vols. $37 \mathrm{~cm}$. - La edición facsímil en Genève: Slaktine Reprints 1995. - «Le Dictionnaire historique et critique declara significativamente Larousse-, œuvre de génie qui a marqué dans l'histoire de l'esprit humain et qui a exercé une immense influence sur la direction des idées au XVIII ${ }^{e}$ Siècle. La Réforme avait ouvert la porte au livre examen; Bayle fit aboutir logiquement cette liberté au doute, qu'il erigea en système, et qui devint entre ses mains une arme redoutable avec laquelle il battit en brèche toutes les croyances plus ou moins surannées. L'Encyclopédie de Diderot était en germe dans ce travail prodigieux que l'auteur trop modeste appelait une compilation informe de passages cousus à la queue les uns les autres. On y trouve une foule d'articles où le sens, le raisonnements, la critique se montrent dans tout leur puissance, et où se déploie une érudition qui eût suffi à dix bénédictins. Bayle ne recherchant qu'un texte, disons mieux, un prétexte pour développer ses idées, n'a introduit aucune méthode régulière dans son livre; pourvu qu'un nom se rattache d'une manière quelconque à un système, à une thèorie, cela lui suffit pour asseoir une série de raisonnements qui conduisent tous au même terme, le doute». LAROUSSE, c., I, p.XVIII y ss. Contemporánea de la estancia de Llorente en el exilio es la edición de París: chez Desoer, libraire, Rue Christine, 1820,16 vols. in- $8^{\circ}$. Reproduce la «nouvelle édition» de Jacques Georges de Chaufepié (1702-1786) editor literario, que añade notas y extractos del mismo Chaufepié y de otros. Esta edición es precisamente la más apreciada por sus adiciones y por su cómodo formato.- No obstante, había sido particularmente popular -tanto por el mismo asunto que conmmovió la pública opinión como por el oportunismo de sus páginas- otra obra de P. BAYLE, Pensées diverses sur la comète, que no solía faltar de la biblioteca de las personas curiosas e ilustradas. Cfr. una edición de esta obra, crítica y puesta al día, por Pierre Rétat que reproduce la anterior edición -también crítica y anotada- de A. Prat. Paris: Nizet 1984, 2 tomos. - En fin, no se puede pasar por alto que, ya en el primer tercio del XVIII, habían sido publicadas, si no unas Obras completas, sí, al menos, varios volúmenes de Euvres diverses de Mr. Piere BAYLE, professeur en Philosophie et en Histoire à Rotterdam: contenant tout ce que cet Auteur a publié sur des matières de Théologia, de Philosophie, de Critique, d'Histoire et de Litterature, excepté son Dictionnaire historique et critique. À La Haye: chez P. Husson, T. Johnson, P. Gosse, J. Swart, H. Scheurleer, J. van Duren, R. Albert, C. Le Vier, F Boucquet, 1727-1731, 4 vols. El tercero se divide en dos partes. En el

Inquisidores contra la Inquisición

Hispania Sacra 55 (2003) 
103.- Vingt volumes in quarto, reliés en parchemin, en espagnol, dont Annales $d u$ Royaume de Valence ${ }^{320}$, prisés quinze francs, ci

Tous les volumes ci-dessus désignés reliés. Suivent les brochures ${ }^{321}$

104.- Vingt deux volumes in 12 dont HUME, Histoire d'Angleterre ${ }^{322}$ et Biographie des Desmoiselles $(\text { sic })^{323}$, prisés douze francs, ci

105.- Dix volumes in octavo dont Histoire de Jeanne d'Albret ${ }^{324}$, prisés cinq francs, ci . 5

cuarto «l'on trouvera plusieurs ouvrages du même auteur, qui n'avoient point encore été imprimez». Hay edición reprográfica cuya dirección literaria es de Elisabeth Labrousse, y que se prolonga en un $\mathrm{V}$ tomo suplementario -en dos vols., que recogen varias obras menores inéditas y, también, una selección de artículos del Dictionnaire historique et critique-. Un VI tomo publica en facsímil la edición de Amstelodami: apud Joannem Pauli, 1715, los Pierre POIRET (gran oponente de Bayle y de Spinoza), Cogitationum rationalium de Deo, anima et malo libri quattuor, Prólogo y Presentación de Marjolaine Chevalier, Georg Olms Verlag, Hildesheim / Zurich / New York, 1990.

${ }^{320}$ Francisco DIAGO de la Orden de Predicadores, Anales del Reyno de Valencia: tomo primero: que corre desde su población después del diluuio hasta la muerte del Rey don Iaime el Conquistador, compuesto por -----. Impressos en Valencia: en casa de Pedro Patricio Mey ..., 1613, in-folio. - Felipe III le nombró Coronista Mayor del Reyno de Aragón. Sólo pudo publicar un tomo: falleció el 23 de mayo de 1615.

${ }^{321}$ Las palabras en negrita no están subrayadas en el documento.

322 David Hume, Histoire d'Angleterre, Paris 1818-1822, 22 vols. in- $8^{\circ}$. Estos tomos albergan también sendas añadiduras a la obra de Hume: John ADOLPHUS, Histoire d'Angleterre. Depuis l'avènement de Georges III jusqu'à la conclusion de la paix de 1783. - John AIKIN, Histoire d'Angleterre. Précis des événements arrivés depuis l'année 1783 jusqu'à 1820. - Cfr. et. la edición contemporánea al autor, ID., Histoire d'Angleterre, traducción de l'abbé Antoine-François Prévost d'Exiles, London 1766, 6 vols. in-12 $2^{\circ}$.

${ }^{323}$ Madame DufRENOY, Biographie des jeunes demoiselles ou Vies des femmes célèbres depuis les hébreux jusqu'à nos jours, Paris: à la Librairie de l'Education d'Alexis Eymery, 1820. - Existe también una $" 2^{\mathrm{e}}$. édition rev., corr. et augm.: ouvrage destiné à l'instruction de la jeunesse, Imprimerie Fain, 4 vols., $18 \mathrm{~cm}$. - Más antiguos son otros diccionarios de personalidades femeninas como el de L'abbé Joseph DE LA PORTE (1713-1819), Histoire littéraire des femmes françaises, Paris: Lacumbe, 1769,5 vols. in- $8^{\circ}$. - O también su contemporánea: J.-François DE LA CROIX, marquis de Castries de Compiègne, Dictionnaire historique portatif des femmes célèbres, contenant l'histoire des femmes savantes, des actrices, et généralement des dames qui se sont rendues fameuses dans tous les siècles par leurs aventures, les talents, l'esprit et le courage, Paris: Cellot, 1769, 2 vols. In-8. - Otros títulos que hacen patente el interés por la personalidad femenina característico de la época: Les femmes galantes de l'Antiquité, L' Ecole des filles, Histoire des Amazones, Les illustres françaises, Les Impératrices romaines (de Serviez), Rhétorique de Demoiselles, Les Études des Demoiselles etc.. Cfr. S. TUCOO-CHALA, Panckoucke, c., catálogos ad finem.

324 Marie-Emmanuel-Guillaume-Marguerite THÉAULON (1787-1841), Pier-François-Adolphe CARMOUCHE (1797-1868), Claude-Louis Marie MARQUIS DE ROCHEFORT-LUÇAY (1790-1871), Jeanne d'Albret ou le Berceau, comédie en 1 acte et en vers. Représentée au Théâtre-français (Paris) 30 avril 1821. Imprimé à Paris: Delavigne (etc.), 1821, 26 pp., $21 \mathrm{~cm}$. (Conociendo a Llorente, sabemos que no le pasó inadvertida la noticia de esta representación) - Mademoiselle VAUVILLIERS, Histoire de Jeanne d'Albret, Reine de Navarre, Paris: F. Guitel, 1818, 3 vols. in- $8^{\circ}$, avec un portrait. Composé avec soin. 
106.- Douze volumes in octavo dont Lettres de Mr. DE $\mathrm{S}^{\mathrm{t}} \mathrm{MARTIN}^{325}$ prisés trois francs, ci 3

107.- Trente un volumes dont Biographie des contemporains par JOUY ETC. ${ }^{326}$, pri-

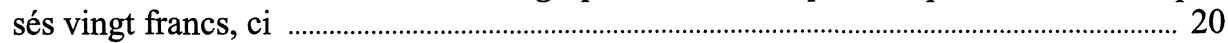

108.- Quatorze volumes petit in quarto, Bible $e^{327}$, en espagnol, prisés douze francs, ci

109.- Quatorze volumes in octavo et in douze dont Esprit des Lois par MONTESQUIEU $^{328}$, Philosophie morale ${ }^{329}$, en espagnol, prisés dix francs, ci

325 Marquis Louis-Claude DE SAINT MARTIN, Lettre à un ami ou Considérations politiques, philosophiques et religieuses sur la Révolution française, Paris: Migneret, an. III (1795) in- $8^{\circ}$. - Pese a que el Inventaire dice Lettres, es probable que se refiera a esta Lettre -la obra más recordada del Marquis de Saint Martin-y que el plural se haya introducido por la pluralidad de ejemplares.

${ }^{326}$ Antoine-Vincent ARNAULT, Antoine JAY, Victor-Joseph-Étienne JOUY, Étienne-François BAZOT, Biographie nouvelle des contemporains ou Dictionnaire historique et raisonné de tous les hommes qui, depuis la Révolution française ont acquis de la célébrité ... soit en France, soit dans les pays étrangers, Paris: Librairie Historique, 1820-1825, 20 vols. in- $8^{\circ}$./ Nouv. Edit. rev. et considérablement augm. Paris: Belin, 1788, 2 vols. in- $8^{\circ}$.

${ }^{327}$ La Biblia Vulgata latina traducida en español y anotada conforme al sentido de los Santos Padres y espositores católicos por el P. PHELIPE SCIO DE SAN MIGUEL. En Valencia en la Oficina de Joseph y Thomas de Orga, 1791-1793, 10 vols. in-folio. «Primera traducción castellana de la Biblia Vulgata. El Concilio de Trento prohibió leer las Sagradas Escrituras en lengua vulgar, pero el Tribunal de la Inquisición en su Decreto de 20 de diciembre de 1782 toleraba las versiones con tal de que estuviesen con notas históricas y dogmáticas». «Esta primera edición es magnífica y su corrección honra a las prensas valencianas. Costó a los editores 16.000 pesetas, cantidad enorme si se considera el valor de la moneda en aquel tiempo. Su precio de salida fue 1.300 reales sin láminas y las láminas aparte se vendían por 700 reales». Es decir, 175 a 200 pesetas sin láminas. La edición con láminas, 300 pesetas, por lo menos. Cfr. A. PALAU Y DULCET, Manual del librero hispano americano, c., tomo $2^{\circ}$, Librería anticuaria de A. Palau, Barcelona 1947, donde se pueden ver muchas ediciones de la Biblia Vulgata en latín, en castellano etc, pp. 211-223. Las ediciones de Scío se multiplicaron con un extraordinario prestigio que todavía hoy conserva. Por estos aledaños bibliográficos debía de moverse Llorente con toda probabilidad. Naturalmente ni por el precio ni por el formato se trata de la primera edición, sino de otra que obedecía a un proyecto de divulgación popular.

${ }^{328}$ Charles de Secondat, Baron de la Brede et de MONTESQUIEU, De l'esprit des lois, Paris: chez Lefèvre 1816, 6 vols. - Poco más tarde, aparece la edición de Paris: Menard et Desenne fils, 1819, 5 vols. - No hace falta decir que de las obras de Montesquieu ha habido infinidad de ediciones. Incluso ediciones de las Euvres complètes: recuérdese, v.g., aunque no sean completas, Euvres de Monsieur de MONTESQUIEU, Nouvelle édition, revue, corrigée et considérablement augmentée en 6 vols., Amsterdam 1781. Las ediciones que aquí se citan, lo son por su proximidad a Llorente.

${ }^{329}$ Emanuel, Conde TESAURO (1592-1675), Filosofia Moral: derivada de la alta fuente del grande Aristóteles Stagirita. Escribiola en toscano el Conde ------, Turinense. Tradúcela Gómez de la Rocha y Figueroa, Madrid, s.n., 1682. - Contemporánea es la edición de Lisboa: Antonio Craesbeeck de Mello, 1682. - Más próxima a Llorente es la edición de Barcelona: Imp. de Pedro Escuder en la Calle Condal 1750 in- $4^{\circ}$ - Y algo posterior es la de Madrid: Joachim de Ibarra, 1776. - Bastantes ediciones, por tanto; se hacen más raras en el comienzo de los años 800 . - No debe omitirse la obra de Pierre NICOLE, que se difundía en España a comienzos de siglo: Ensayos de moral contenidos en diversos tratados sobre muchas obligaciones importantes..., traducidas por don Francisco Antonio de Escartín, Imprenta Real, 1800-1801, 4 vols. in-8.

Inquisidores contra la Inquisición

Hispania Sacra 55 (2003) 
110.- Vingt sept volumes in octavo et in douze dont Traité d'économie politique de SAY 330 en espagnol prisés dix francs, ci .............................................................................. 10

111.- Trente volumes in octavo dont Vie de Wasington (sic) ${ }^{331}$, en espagnol prisés trois francs, ci

112 - Six volumes in folio demi-reliures Athlas ( sic $^{332}$ ) historique de MoMAs 333 prisés douze francs, ci .................................................................................................. 12

113.- Trois volumes in folio, reliés, Athlas de BORIN ${ }^{334}$. prisés vingt francs, ci ... 20

114.- Onze volumes in folio, reliés, Athlas $^{335}$ divers, prisés dix francs, ci .............. 10

115.- Neuf volumes in folio dont Théâtre des villes ${ }^{336}$, en latin, prisés quinze francs, ci

330 Jean Baptiste SAY, Traité d'économie politique, $2^{\mathrm{e}}$ ed. entièrement refondue et augmentée d'un épitomé des principes fondamentaux de l'économie politique, Paris: A.-A. Renouard 1814, 2 vols. in- $8^{\circ}$.

331 Cfr. supra item 59. Una vez más, se trata sin duda de volúmenes para vender.

332 Por atlas. Lo mismo en los dos item siguientes.

333 Claude BUY DE MOMAS, Atlas historique et géographique, Paris: l'auteur, 1762, 2 vols. in-folio.

${ }^{334}$ Muy probablemente se trata de Bonne, mal oído por el greffier. En efecto, Rigobert BONNE (1727-1795) es un geógrafo y cartógrafo muy competente que señala -a la cabeza de otros cartógrafos y geógrafos- un momento de brillantez de Francia sobre las naciones europeas. A Bonne se debe hagamos justicia al magnífico en tantas ocasiones Diccionario de Espasa citándolo en la voz Mapa- la Carte de l'Etat Major grabada al cobre a escala 1/80.000. Ella sirvió de base para levantar la Carte de France en 596 hojas a escala $1 / 100.000$ y la del Ministerio de Trabajos en 80 hojas a escala 1/200.000. A BONNE se debe asimismo, con la colaboración de Nicolas DESMAREST, el Atlas encyclopédique, contenant la géographie ancienne et quelques cartes sur la géographie du Moyen-âge, la géographie moderne, etc...., Paris: Hôtel de Thou 1787-1788, 2 vols. in $4^{\circ}$.- El Tableau de la France había visto ya la luz en 1764. - Conviene citar para ilustración del lector y por la similitud del apellido con el Borin del texto del Inventaire a Jean-Baptiste-Geneviève-Marcelin, baron de BORY DE SAINT VINCENT, Essay sur les Isles Fortunées et l'Antique Atlantide, ou précis de l'Histoire générale de l'Archipel des Canaries, Paris: Ardouin, an. XI (1803) in- $4^{\circ}, 2$ h., 532 pp., 3 mapas, 7 láminas. - También de BORY DE SAINT VINCENT, Géographie de la Péninsule Ibérique, Paris 1818 y, asimismo los Voyages dans les quatre principales îles des mers de l'Afrique, de 1804 -con un excelente mapa de la isla de Réunion-. Pero estrictamente hablando estas obras no son atlas. El resto de obras géográficas publicadas por Bory es posterior a la muerte de Llorente.

${ }^{335} \mathrm{La}$ época ilustrada -y Francia va a la cabeza- experimenta una gran afición por conocer el planeta -y sus continentes, pueblos y regiones- en su geografía física. También -como ya se ha visto- en su geografía descriptiva, humana, social, política: en todos sus aspectos antropológicos -tal como entonces se piensan- en cualquier caso. Delisle (1675-1676) publica su atlas con 98 mapas. Auville (1697-1782), su Atlas général con 211 mapas. Se plasman globos terráqueos y mapas en relieve. El presentado a Luis XVI por el Conde Gravie de Vergennes tenía 26 metros de diámetro. En España, el Atlas de Tomás López (1765-1802) tenía 102 hojas. Y no se puede olvidar que en España uno de las obras de este género más famosas y válidas -y muy posiblemente obraba entre esos atlas que globalmente se citan en el Inventaire- es la de Emmanuel-Auguste-Dieudonné, COMTE DE LAS CASAS (1766-1842), Atlas histórico, cronológico, geográfico, etc..., traducido, corregido y aumentado por un Español Americano, Paris: Librería Hispano-Francesa de Bossange Padre, 1826. La primera edición del Atlas en francés es muy anterior a la muerte de Llorente. De hecho fue publicada bajo el pseudónimo de LE SAGE en Paris 1802-1803. Incluso la traducción inglesa había ya aparecido en 1813.

Inquisidores contra la Inquisición Hispania Sacra 55 (2003) 
116.- Trente sept volumes in dix huit et in douze, brochés, dont Gil Blas ${ }^{337}$, prisés trois francs, ci

Dans une autre pièce étant ensuite de la précedente 338

117.- Trente paquetes environ de vingt cinq volumes chaque ${ }^{339}$, troisième volume des Mémoires sur la révolution d'Espagne, et autres diverses de l'Histoire de l'Inquisition, prisés quatre vingt dix francs, ci

336 Georg BRAUN (1540-1622), Theatrum. Illustriores Hispaniae Urbes. Civitates Orbis Terrarum. (Hasta aquí el frontispicio exterior. Sigue el título del libro) Illustriorum Hispaniae Urbium Tabulae cum Appendice celebriorum alibi aut olim aut nunc parentium Hispanis, aut eorum civitatum commerciis florentium. Amstelodami: ex officina Joannis JANSSONII, 1657 (aprox.), ejemplar 330 de la edición única de 980 ejs. y elaborada con reproducciones facsímiles. Acompaña al volumen principal de los facsímiles -y dentro del mismo estuche- otro volumen menor, hermoso y muy bien encuadernado, con la traducción castellana, titulado Teatro de las más ilustres ciudades de España y Portugal, precedido de un Estudio de Elena SANTIAGO PÁEZ. La traducción castellana es de Mauricio Wácquez, Ebrisa / Lunwerg ed., Barcelona 1996 / 1657 (fecha de los facsímiles de las planchas de Jansson). - Se trata por tanto de un libro con larga historia interna. "A mediados del siglo XVI, en Amberes y Colonia, un grupo de intelectuales, científicos y personas relacionadas con el mundo del libro, decidieron emprender un proyecto editorial muy en consonancia con las aspiraciones de universalidad y ansias de conocimiento del momento: la publicación de un Atlas con vistas de ciudades de todo el mundo. Este proyecto era un reto y una aventura pues había de partir de cero. Los tiempos modernos y los exigentes lectores que iban a adquirir la obra, requerían que las imágenes fueran fidedignas y al mismo tiempo bellas y atractivas y que los textos que las acompañaran tuvieran también una base científica sólida e interesante. - Georg Braun y Frans Hogenberg, el primero más centrado en la labor editorial y el segundo en la ejecución de los grabados, se pusieron en marcha para localizar en todo el mundo corresponsales que pudieran enviarles, por una parte, vistas de ciudades que reunieran dos requisitos básicos para su obra: autenticidad y belleza, y por otra, textos que hablaran de ellas. Cuando aquellas no existían, procuraron que cartógrafos profesionales, pintores de paisajes o viajeros ocasionales las hicieran ex profeso para ellos. Así lograron reunir cincuenta y nueve imágenes que, una vez reelaboradas, y con un formato semejante, se grabaron y publicaron en un volumen titulado Civitates Orbis Terrarum. - El éxito editorial fue tan grande que a lo largo de los años se fueron publicando hasta seis volúmenes que reunían más de quinientas vistas de ciudades. - En esta aventura editorial España fue muy afortunada pues contó con el mejor reportero gráfico de los que colaboraron en el Civitates, el entonces dibujante aficionado que llegó a ser pintor de miniaturas del emperador Rodolfo II, Georg Hoefnagel (o, también, Joris Hoefnagle Antverpianus -Amberes 1542.Viena 1600). A él se debe casi la totalidad de los dibujos con vistas de ciudades españolas, hechas durante su viaje a Andalucía entre los años 1563 y 1567 . Hoefnagel nos legó la imagen de un país de grandes contrastes geográficos, bellas poblaciones, fértiles campos y gentes amables y laboriosas. - Estos diseños, tras ser grabados por el experto Hogenberg, fueron incluidos en cinco tomos del Civitates Orbis Terrarum, que fueron apareciendo entre 1572 y 1597. - Muchos años más tarde, en 1657, Johannes Janssonius compró las planchas grabadas y publicó de nuevo las vistas de ciudades españolas reunidas en un solo volumen bajo el título Theatrum. Hispaniae Urbes. E. SANTIAGO PÁEZ, c., 7-8.

337 Parece claro que son volúmenes para vender o intercambiar. Cfr. supra, item 79.

${ }^{338}$ Las palabras en negrita no van subrayadas en el documento.

${ }^{339} \mathrm{Se}$ trata de volúmenes de esas dos obras del propio Llorente, que el autor conservaba todavía sin vender.

Inquisidores contra la Inquisición

Hispania Sacra 55 (2003) 
Dans la première pièce ci-dessus désignée 340

118.- Trente trois volumes in octavo, brochés, dont Histoire des Jésuites ${ }^{341}$, prisés cinq francs, ci

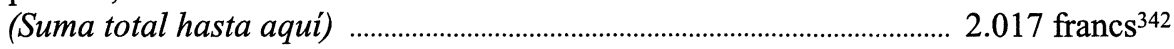
/I

(Suma total hasta aqui)

2.017 francs

119.- Quarante sept volumes de divers formats dont Dictionnaire de les fables de Noël ${ }^{343}$, Coup d'œil sur Lisbonne etc. ${ }^{344}$, prisés dix francs, ci

Dans une petite chambre au cinquième étage sur laquelle étaient apposés les scellés de M. le Juge de Paris 345

120.- Six cents exemplaires des Observations sur le Roman de Gil Blas par Mr. LLORENTE ${ }^{346}$, prisés quatre vingt dix francs, ci 90

121.- Cinquante cinq paquets, environ de vingt cinq volumes chaque, volumes divers des Mémoires sur la révolution d'Espagne ${ }^{347}$ prisés deux cents francs, ci ......... 200

122.- Environ sept cents brochures, Compte rendu des Cortes, prisés vingt cinq francs, ci

Total du mobilier et des libres: 2.358 francs

340 Las palabras en negrita no van subrayadas en el documento.

341 S.-N.-H. LINGUET, Histoire impartiale des jésuites: depuis leur établissement jusqu'à leur première expulsion, sl: s.n., d'après Barbier, 17682 vols. in-12. - En 1824 Balzac publicará también sus páginas de Histoire impartiale des jésuites, que Llorente, naturalmente, ya no pudo leer. Pero se demuestra que el título de Linguet había tenido aceptación.

$342 \mathrm{El}$ resultado de la suma es de 2.033 y no de 2.017 , salvo error mío en el cálculo.

343 François-Joseph-Michel NOËL (1755-1841), hijo de un sencillo comerciante, estudió de favor en París en el mismo colegio en que lo hacía Robespierre. En su afán de salir adelante en la docencia llegó a recibir órdenes menores. Su enardecido sentimiento revolucionario le empujó a comprometerse en la política y, así, ocupó cargos de representación en la diplomacia de la República. Compilador y erudito, gramático y pedagogo, escribió muchas obras meritorias y, sobre todas ellas, diccionarios que merecieron el aprecio de la opinión francesa de su generación. F.J.M. NoËL, Dictionnaire de la Fable ou Mythologie grecque, latine, égyptienne, celtique, persanne, syriaque..., Paris: Le Normant, imprimeur et libraire, an. X (1801), 2 vols. $21 \mathrm{~cm}$. - En 1810 salía ya la tercera edición «rrevisada, corregida y considerablemente aumentada»-, también en 2 vols., $21 \mathrm{~cm}$., de Le Normant. - En 1815 apareció el Abrégé de la mythologie universelle: ou Dictionnaire de la fable, Paris: Le Normant, un solo tomo de VIII +661 pp., $17 \mathrm{~cm}$.

344 Charles-Victor D'HAUTEFORT, Coup d'œil sur Lisbonne et Madrid en 1814, suivi d'une Mémoire politique concernant la Constitution promulguée par les Cortes à Cadiz et d'une Notice sur l'Etat moderne des sciences mathématiques et physiques en Espagne, Paris: Delaunay, 1820, IV + 440 pp.

345 Las palabras en negrita no van subrayadas en el documento

346 Volúmenes sin vender todavía. Las Observaciones críticas habían salido a luz en 1822 en dos diversas ediciones: una en Madrid: Imprenta de T. Albán y Compañía; y otra en Paris: Imp. de Moreau. Parece claro, por tanto, que los ejemplares que había en la casa de Paris eran de la edición francesa.

347 Importante stock todavía sin vender. 


\section{Déclaration}

Déclare Madame ${ }^{348}$ María Nieves de Vinuesa ${ }^{349}$, veuve de M. Antonio Rubio qu'une partie de mobilier ci-dessus désigné lui appartient tant comme l'ayant payé de ses propres dîners, que comme lui ayant été abandonnés $\left(s i c^{350}\right)$ par le dit sieur Llorente, aussi qu'elle se réserve de les preuves lorsqu'elle en sera requise. ${ }^{351}$

Et $\mathrm{a}, \mathrm{M}^{\mathrm{e}}$. Rubio, signé en fin de sa déclaration, où il s'est trouvé dix mots rayés comme nuls.

(Firma y rúbrica de:) María Nieves de Vinuesa

Contre la quelle déclaration $M$. Ruidíaz a fait toutes protestations et réserves. Et a signé

(Firma y rúbrica de: $)^{352} \quad$ Ruidíaz

Déclare en outre M. Ruidíaz qu'il est ${ }^{353}$ réclamé contre la succession par le propriétaire de la maison où il est procédé neuf mois du loyer de l'appartement de $\mathrm{M}$. Llorente à raison de six cent soixante francs par an ${ }^{354}$.

Et qu'il a lui-même à réclamer le remboursement de diverses dépenses qu'il a faites pour la succession depuis le décès de $\mathrm{M}$. Llorente et dont il justifiera au besoin.

Il déclare en outre que M. Llorente avait remis ${ }^{355}$ à MM. Coreard, Pélissier, Rosa ${ }^{356}$

348 Sigue una palabra incompleta y tachada que probablemente es Doña.

349 Antonio Rubio está bien localizado desde el artículo que escribiera M. NúÑEZ ARENAS, Llorente en Burdeos en «Bulletin Hispanique» 30 (1928) 72-74. - Cfr. asimismo las interesantísimas noticias que sobre la Viuda de Rubio nos brinda G. DUFOUR, Llorente en France, c., 355-356. Parece que la sobrina de Llorente se hallaba bien metida en los manejos de la conspiración carbonaria y que poseía documentos políticos muy interesantes que habían pertenecido a su difunto tío. Por el año 1825 -antes, por tanto, del proceso de sucesión hereditaria a los bienes de Llorente- estaba deseosa de entrar en negociaciones con los libreros para sacarles partido económico. El sieur Robillot de que hablan los informes de la policía es a mi entender el propio Rubio, apellido mal entendido y mal transcrito por los agentes franceses.

350 Por abbandonée, concertando con partie.

351 Sigue aquí una línea y media tachada que decía por error: Contre la quelle déclaration Mr. Ruidiaz a fait toutes protestations, adelantando el texto posterior a la firma necesaria de María Nieves de Vinuesa.

352 Siguen tres palabras tachadas: Et a signé.

353 Siguen cuatro palabras tachadas: dû par la succession.

$354 \mathrm{El}$ propietario reclamaba contra la sucesión el cobro de 9 meses de alquiler. De hecho, como se puede ver posteriormente, esas mensualidades las había pagado Ruidíaz en su convicción de ser único heredero.

355 Sigue una palabra tachada.

$356 \mathrm{El}$ librero Rosa merece ser señalado porque fue él quien editó la traducción castellana de la célebre novela que escribió LOUVET DE COUPEURAY, Aventures du Baron de Faublas. Esta obra, abiertamente licenciosa, hizo todo el ruido que páginas de ese jaez suelen producir. La primera edición advertía que la traducción había sido realizada por D. Eugenio SANTOS GUTIÉRREZ, «Secretario de Juan S. (sic) Llorente» y aparecía bajo el título de Aventuras del Baroncito de Foblás, Paris 1820. Es más, el librero Rosa, en los catálogos de venta de sus libros en castellano, había deslizado la atribución a D.S.A. Llorente de la paternidad de la traducción de las escabrosas Aventuras. Las abreviaturas

Inquisidores contra la Inquisición

Hispania Sacra 55 (2003) 
et autres libraires, pour en faire la vente, de différens $\left(\right.$ sic $\left.{ }^{357}\right)$ exemplaires des Observations sur le Roman de Gil Blas, du produit desquels ils doivent tendre compte.

Enfin, qu'il est à la connaissance que $\mathrm{M}$. Llorente de $\mathrm{Cádiz}^{358}$ a fait l'avance d'une somme de trois mille francs environ pour les frais d'inhumation du défunt et qu'il dépend de la succession du défunt six cents francs de rente sur l'Etat dont les titres sont entre les mains de Madame Houllier.

Il a été vaqué à tout ce que dessus

(siguen a pie de esta plana recta del folio los "paraphes»)

/l

depuis la dite heure de neuf du matin jusqu'à celle de trois de relevée par double vacation tant à l'inventaire des objets ci dessus qu'à recevoir les déclarations des parties. Ce fait, ne s'étant plus rien trouvé à dire ni comprendre au présent inventaire, il a été tenu pour clos et arrêté. Et les objets ci dessus décrits sont restés en la garde et possession $^{359}$ du dit sieur Ruidíaz, qui le reconnaît et est en charge comme dépositaire de justice pour les représenter quant et à qui il appartiendra. Déclarant qu'il n'est pas à sa connaissance qu'il dépende aucune autre chose de la dite succession.

Et ont M. Ruidiaz, M. Delaunay, M. le commissaire priseur signé avec les notaires, la dite $\mathrm{D}^{\mathrm{e}}$. Dacier gardienne des scellés ayant déclaré ne savoir écrire ni signer, le tout après lecture

Fz. Ruidiaz

Delaunay

Martinet

Riant

Marchoux (Todas las firmas con sus respectivas rúbricas. Al margen aparece la advertencia debidamente paraphée:) Rayé vingt trois mots comme nuls ${ }^{360}$.

\footnotetext{
efectivamente no decían estrictamente que el eclesiástico español fuera el auténtico traductor; pero eran próximamente susceptibles de ser interpretadas contra Llorente. Porque Gutiérrez era -sí- el - secretario de Llorente. No hace falta ponderar cómo todo el mundo procura hilar fino en semejantes trances. Pero Llorente de momento no reaccionó: y era un asunto en que el que calla otorga. Sólo cuando Llorente pudo calcular el desdoro que se le venía encima por aquella conexión sugerida en el frontispicio del libro y más claramente achacada en los prospectos -, escribió en El Imparcial una carta desentendiéndose de tal vinculación y asegurando que «por eso he hecho al librero Rosa confesar que él hizo imprimir mi nombre en lugar del verdadero traductor por haberle parecido que así lograría mejor venta». En cualquier caso, está bien claro que Llorente había tardado más de un año en protestar. El libro había salido de las planchas de Rosa en agosto de 1820; la carta de Llorente apareció en El Imparcial el 19 de diciembre de 1821. Llorente continuó su amistad con Eugenio Gutiérrez y también sus negocios con el librero Rosa. Cfr. G. DUFOUR, Llorente en France, c., 294-295.

357 Por différents.

358 Cfr. sobre Juan Antonio Llorente (sobrino), E. DE LA LAMA, Llorente, un ideal de burguesia, c., 204-205 y 211-212.

359 Siguen varias palabras tachadas.

${ }^{360}$ Siguen dos líneas del registro tachadas, antes de la anotación válida del registro.
} 
Enregistré à Paris au Bureau $n^{\circ} 4$, le douze juin 1823 f $^{\circ} 2, n^{\circ}$ case 8 . Reçu huit francs, et quatre vingt centimes pour la dixième

$$
\text { Cruvy }^{361} \text { (con su rúbrica) }
$$

1.D. Minuta del «Procès verbal» de 16 de septiembre de 1826

\section{Registré $\mathrm{n}^{\circ} 3998^{362}$ \\ Fait expédition}

L'an mil huit cent vingt six le samedi ${ }^{363}$ seize septembre, heure de midi.

Par-devant $\mathrm{M}^{\mathrm{e}} 364$ Pierre Corbin ẹt son collègue, notaires de Paris soussignés, a comparu

M. Michel Barré, employé au Trésor Royal, demeurant à Paris, rue neuve $\mathrm{S}^{t}$ Roch $\mathrm{n}^{\circ} 8$ «agissant au nom et comme tuteur d'Antoinette Elisa Llorente, fille mineure naturelle et légalement reconnue de feu M. Jean Antoine Llorente, laquelle est en cette qualité habile à recueillir les trois quarts de la succession du dit sieur Llorente».

Le dit sieur Michel Barré, assisté de $\mathrm{M}^{\mathrm{e}}$ Darlu, avoué près le tribunal civil de première instance du Département de la Seine, demeurant à Paris, rue de Louvois $\mathrm{n}^{\circ} 4$, son conseil à ce présent.

Lequel a dit que, par exploit du ministère de Couturier, huissier à Paris, en date du quatorze septembre, présent mois, enregistré, il a fait faire sommation au sieur Alexandre Fernández Ruidíaz, négociant demeurant à Paris, rue Notre Dame des Victoires $\mathrm{n}^{\circ} 40$, de comparaître le jour et l'heure sus-dits en l'étude du dit $\mathrm{M}^{\mathrm{e}}$ Corbin, l'un des notaires soussignés, à l'effet d'y consentir la rectification de l'inventaire fait à la requête du dit Sieur Ruidíaz le neuf juin mil huit cent vingt trois après le décès de $M$. Jean Antoine Llorente par le ministère de $\mathrm{M}^{\mathrm{e}}$ Marchoux, prédécesseur du dit $\mathrm{M}^{\mathrm{e}}$ Corbin, dans lequel le dit sieur Ruidíaz a pris la qualité d'habile à se porter seul (siguen los "paraphes» de validación) // et unique héritier du feu sieur Llorente et de reconnaître par acte authentique les droits qui appartiennent à la mineure Antoinette Elisa Llorente dans la succession du dit défunt, comme étant sa fille naturelle légalement reconnue; et que faute par le dit sieur Ruidíaz de satisfaire à la dite sommation, le requérant se pourvoirait à telles fins que de droit dans l'intérêt de sa pupille.

Le dit sieur Barré, assisté comme dit est, a requis acte de sa comparution et dire et défaut contre le dit sieur Ruidíaz dans le cas où il ne comparaîtrait pas ni personne pour lui.

${ }^{361} \mathrm{Si}$ he interpretado bien los rasgos poderosos de la firma del receveur de droits d'Enregistrement, que asiste al proceso.

362 El papel es sellado -como de ley-.

363 Tachado: onze

${ }^{364}$ Abreviatura de Maitre, título reservado a los notarios, abogados o gentes de leyes.

Inquisidores contra la Inquisición

Hispania Sacra 55 (2003) 
Et à l'appui de son dire ci dessus M. Barré a représenté l'original de la sommation ci dessus énoncé, lequel est demeuré ci joint, après que dessus mention en a été faite par les dits notaires.

Et ont, le dit sieur Barré et $\mathrm{M}^{\mathrm{e}}$. Darlu, son avoué, signé après lecture faite.

(Firmas y rúbricas de:) Darlu

M Barré

Et à l'instant est comparu M. Ruidíaz, ci-dessus nommé, lequel, après avoir pris connaissance de l'acte de naissance de la mineure, a déclaré ne pas s'opposer à la rectification du dit inventaire sous toute réserve des droits. de qui il appartiendra.

Et a signé après lecture

(Firma y rúbrica de:) Ruidíaz

En conséquence le dit sieur Barré assisté, comme dit est, a requis les notaires soussignés de ne délivrer ni expédition //

ni extrait du dit inventaire sans y joindre expédition ou extrait du présent procès verbal pour la conservation des droits de sa pupille.

Dont acte fait et arrêté le présent procès verbal à Paris en l'Etude, les jours, mois et an ci-dessus, et les parties ont signé avec les notaires après lecture faite

(Al margen se hace constar:) Rayé dans le cours du présent procès verbal un mot comme nul. (y siguen las rúbricas de validación de dicha advertencia)

(Siguen las firmas y rúbricas de:) Darlu, M Barré, Ruidíaz

(y de los dos notarios:) Corbin

Vernois 365

Enregistré à Paris le vingt six septembre $1826, \mathrm{f}^{\mathrm{o}} 141-\mathrm{n}^{\circ} \mathrm{c}\left(\text { ase } 8^{\mathrm{e}}\right)^{366}$. Reçu deux francs et vingt centimes pour dixième

--- (Firma y rúbrica de:) Cruvy 367

365 Interpretación verosímil. De hecho, Vernois es el único notario que aparece en el elenco del Almanach Royal de 1828 -p.787-, con apellido concluido en el grupo ois, que es el más inequívoco de la firma.

366 Lo que va entre paréntesis, es lectura probable.

367 Lectura probable. Sería aventurado interpretar como lectura cierta y exacta algunos apellidos de oficiales del Registro, a no ser que vengan escritos v.g. en el Almanach Royal. Pero no he encontrado ningún apellido, siquiera aproximado, entre las listas de dicho Almanach. En cualquier caso, tal ausencia no es significativa: porque el carácter del Almanach es meramente informativo. 
1.E. «Exploit» del «Huissier» del Primer Tribunal Civil del Departamento del Sena comunicando a M. Barré que ha intimado la presencia de Alejandro Fernández Ruidiaz ante el Notario Corbin para rectificar el inventario y rectificar la partición de los bienes del finado Llorente

L'an mil huit-cent vingt six, quatorze ${ }^{368}$ septembre, à la requête de monsieur Michel Barré, employé au Trésor Royal, demeurant à Paris, rue neuve $\mathrm{S}^{\mathrm{t}}$ Roch $\mathrm{n}^{\circ} 8$, au nom et comme tuteur d'Antoinette Elisa Llorente, fille mineure naturelle reconnue de feu M. Jean Antoine Llorente, laquelle est en cette qualité habile à se porter héritière pour les trois quarts du dit sieur Llorente, par lequel requérant domicile est élu en l'étude de $\mathrm{M}^{\mathrm{e}}$ Darlu, avoué près le Tribunal de première instance de la Seine, demeurant à Paris, rue de Louvois $n^{\circ} 4$,

j'ai ${ }^{369}$-Gabriel Marie Couturier, huissier près le 1 Tribunal Civil du Département de la Seine, séant à Paris rue de la Jussienne $n^{\circ} 11$, patenté le 23 marc d'or $n^{\circ} 29,3^{\mathrm{e}}$ classe, soussigné- signifié et, avec celle ${ }^{370}$ des présentes, laissé copie au sieur Alexandre Fernández Ruidíaz, négociant, demeurant rue Notre Dame des Victoires $n^{\circ} 40$, en son domicile 371 en parlant à la portière de la maison nous a déclaré.

D'un acte dressé le vingt trois septembre mil huit cent vingt par le Maire du Premier Arrondissement de Paris constatant qu'Antoinette Elisa est née à Paris le vingt un du même mois, et que le sieur Jean Antoine Llorente l'a reconnue pour sa fille naturelle à ce que le susnommé n'en ignore.

Et à même requête que dessus, j'ai -huissier susdit et soussigné- fait faire sommation au sieur Ruidíaz de se trouver samedi prochain, seize septembre, heure de midi, en l'étude de $\mathrm{M}^{\mathrm{e}}$ Corbin, notaire à Paris, rue Vivienne $\mathrm{n}^{\circ} 6$, à l'effet d'y consentir la rectification de l'inventaire fait à sa requête, le neuf juin 1823, après le décès de $M$. Jean Antoine Llorente, par le ministère de $\mathrm{M}^{\mathrm{e}}$ Marchoux, prédécesseur du dit $\mathrm{M}^{\mathrm{e}}$ Corbin, dans lequel sieur Ruidíaz a pris la qualité d'habile à se porter seul et unique héritier du feu sieur Llorente; et de reconnaître par un acte authentique les droits que appartiennent à la mineure Antoinette Elisa Llorente dans la succession du dit défunt, comme // étant sa fille naturelle légalement reconnue déclarant au susnommé que, faute par lui de satisfaire à la présent sommation, le requérant se pourvoira à telles fins que de droits dans l'intérêt de sa pupille. - Et je lui ai, en parlant comme dessus, laissé en outre, copie du présent exploit, dont le coût compte six francs $65 \mathrm{c}$.

Original

(Firmado y rubricado:) Couturier

\footnotetext{
368 Aquí está plasmado el sello legal de 25 centimes en sus; seguidamente está tachada la palabra quatorze que había sido repetida.

${ }^{369} \mathrm{El}$ sentido es: J'ai signifié et laissé copie.

370 Se sobreentiende signature, es decir, con las firmas de los presentes.

371 Aquí está omitido el pronombre relativo que. La redacción del huissier es brusca y precipitada. Sería: que en parlant à la portière elle nous a déclaré. Es decir: interpelando a la portera, ella corroboró que aquel era el domicilio de Ruidíaz. Entonces el huissier dejó la copia del acte y la sommation.

Inquisidores contra la Inquisición

Hispania Sacra 55 (2003)
} 


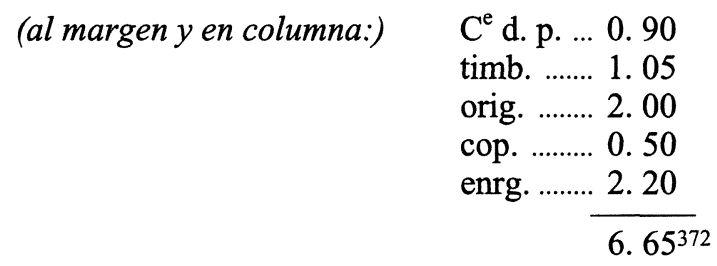

Enregistré à Paris le quinze septembre

Reçu deux francs, 20 dixième

(Firma y rúbrica de:) Bruny (i)

(A pie de página en el ángulo inferior derecho y escrito en sentido perpendicular a las líneas del cuerpo del documento, el nombre del avoué-conseil de M.Barré, destinatario del «exploit»: ) Darlu

${ }^{372}$ Las abreviaturas significan: Compte de paiement (?), timbre, original, copie, enregistrement. Hispania Sacra 55 (2003) 
Minutier Central des Notaires

87, Rue Vieille du Temple -Paris

Llorente, Jean Antoine

Homme de Lettres

Paris

Liquidation et partage

25 mai 1827

Corbin

Cote: ET/XCIII/471

\section{Carpeta, Cote: ET/XCIII/ 471}

25 mai 1827

Procès Verbal d'ouverture de la liquidation de la succession de M. Llorente

3 octobre 1827

Procès Verbal de liquidation et partage

16 janvier 1828

Dépôt d'homologation

6 mars 1828

Quittance à $\mathrm{M}^{\mathrm{e}}$ Marchoux

\section{A. Minuta del Procès Verbal d'ouverture de la Liquidation}

$\mathrm{N}^{\circ} 6008$

Registré ${ }^{373}$

Fait expédition

Fait expédition

${ }^{373} \mathrm{El}$ documento va en papel timbrado, por el valor de las tasas fiscales: uno de 75 céntimos y otro de 50 céntimos -timbre añadido de acuerdo con la ley de 1816-. Los timbres van en la parte superior de la plana recta de cada uno de los dos folios de que consta la minuta.

Inquisidores contra la Inquisición

Hispania Sacra 55 (2003) 
L'an mil huit cent vingt-sept, vendredi, vingt-cinq mai, heure de midi.

Par devant $\mathrm{M}^{\mathrm{e}}$ Corbin, notaire à Paris, soussigné, en l'étude sise à Paris, rue Vivienne $\mathrm{n}^{\mathrm{o}} 6 \mathrm{du}$ dit $\mathrm{M}^{\mathrm{e}}$ Corbin, commis à l'effet des opérations dont il va être parlé aux termes des jugement et ordonnance ci après énoncés.

Est comparu M Michel Barré, employé au Trésor Royal, demeurant à Paris, rue neuve $\mathrm{S}^{t}$ Roch $\mathrm{n}^{\circ} 8$, assisté de $\mathrm{M}^{\mathrm{e}}$ Pierre Darlu, avoué près le Tribunal de Première Instance du Département de la Seine demeurant à Paris, rue de Louvois $n^{\circ} 4$.

M. Barré, agissant comme tuteur d'Antoinette Elisabeth (sic) Llorente, fille naturelle mineure du sieur Jean Antoine Llorente décédé et de demoiselle Françoise Joséphine Houillier, nommé à ces fonctions qu'il a acceptées suivant délibération du conseil de famille de la dite mineure reçue par $\mathrm{M}^{\mathrm{e}}$ le Juge de Paix du canton de Neuilly, arrondissement de $\mathrm{S}^{\mathrm{t}}$ Dénis, Département de la Seine le six juillet mil huit cent vingt quatre, enregistrée.

Lequel a dit:

- que par jugement rendu le dix février mil huit cent vingt sept à sa requête et par défaut contre M. Alexandre Fernandez Ruidiaz demeurant à Paris, rue Notre Dame des Victoires $n^{\circ} 40$, héritier légitime de $M$. Llorente, le Tribunal a ordonné qu'il fût procédé au partage de la succession de $\mathrm{M}$. Llorente entre la dite mineure Antoinette -ayant droit à une portion de sa succession- et M. Ruidíaz -comme son héritier en la qualité susdite-; et ce par devant $\mathrm{M}^{\mathrm{e}}$ Naudin, juge au dit Tribunal, commissaire en cette partie, lequel renverrait les parties pour (esta plana recta el folio está debidamente "paraphée») //

les opérations de détail devant $\mathrm{M}^{\mathrm{e}}$ Corbin, notaire successeur de $\mathrm{M}^{\mathrm{e}}$ Marchoux, qui a dressé l'inventaire après le décès de $M$. Llorente,

- que par ordonnance du dix sept mai dernier M. Naudin a déclaré ouvert le Procès Verbal des opérations à lui déléguées par le dit jugement et a renvoyé les parties devant $\mathrm{M}^{\mathrm{e}}$ Corbin à l'effet de procéder devant lui comme il est ordonné aux articles huit cent vingt huit et suivants du Code Civil.

- Enfin que par exploit de Couturier, huissier à Paris, en date du vingt deux mai mil huit cent vingt sept, il a fait signifier à M. Ruidíaz l'ordonnance dont il s'agit et lui à un même tems (sic) ${ }^{374}$ fait sommation de comparaître aujourd'hui, à la dite heure de midi, en l'étude de $\mathrm{M}^{\mathrm{e}}$ Corbin à l'effet de procéder devant lui aux comptes, liquidation et partage de la succession de M. Llorente, ayant déclaré au dit sieur Ruidíaz que, faute par lui de comparaître aux dits an, jour et heure, il serait donné défaut contre lui et que le requérant se pourvoirait ensuite ainsi qu'il aviserait.

Â l'appui de son dire, $\mathrm{M}$. Barré a représenté à $\mathrm{M}^{\mathrm{e}}$ Corbin l'expédition de l'ordonnance précitée, ensuite de laquelle est l'original du dit exploit de signification et sommation; laquelle pièce est demeuré ci jointe après avoir été revêtue d'une mention d'annexe par le notaire soussigné.

En conséquence, $\mathrm{M}$. Barré a requis $\mathrm{M}^{\mathrm{e}}$ Corbin de lui donner acte de sa comparution et de son dire et de donner défaut contre M. Ruidíaz s'il ne comparait pas, ni personne pour lui, et a signé avec $\mathrm{M}^{\mathrm{e}}$ Darlu après lecture faite.

(Firma de:) Barré (Firma y rúbrica de:) Darlu

374 Por temps. 
et à l'instant

(Al margen izquierdo, escrito en líneas perpendiculares a las del cuerpo del documento, se lee:) Enregistré à Paris le quatre Juin 1827, $\mathrm{f}^{\mathrm{o}} 65, \mathrm{n}^{\circ}$ case $1^{\mathrm{er}}-$ Reçu deux francs et vingt centimes pour $10^{\mathrm{e}}$ (Firma y rúbrica de: ) Cruvy //

est intervenu M. Ruidíaz dont le prénom et demeure sont ci dessus indiqués,

Lequel a dit:

- qu'il se présente pour satisfaire à la sommation qui lui a été faite à la requête de $M$. Barré;

- que non seulement il ne s'oppose pas aux opérations dont il s'agit, mais qu'il requiert encore, en tant que de besoin, $\mathrm{M}^{\mathrm{e}}$ Corbin d'y procéder, se réservant au surplus le droit de faire dans le cours de ses opérations tous dires, réquisitions, protestations et réserves; et a signé après lecture.

(Firma y rúbrica de:) A. F. Ruidíaz

Par suite les comparants se sont d'une commune accord ajournés pour continuer et finir, s'il y a lieu, les dites opérations au trois octobre prochain, époque jusqu'à laquelle M. Corbin dressera sur les pièces et documents qu'ils lui fourniront l'état des comptes et liquidation dont il s'agit.

Dont acte fait et passé dans le lieu et les jour, mois et an sus indiqués et ont les parties et $\mathrm{M}^{\mathrm{e}}$ Darlu signé avec $\mathrm{M}^{\mathrm{e}}$ Corbin après lecture faite.

(Escrito al margen:) Rayé trois mots comme nuls (seguido de las rúbricas de validación)

(Firmas y rúbricas del acta:) Darlu, Ruidiaz, Barré, Corbin, Forqueray ${ }^{375}$

$\mathrm{Et}^{376} / /$

\section{B. Minuta del «Procès" Verbal de Liquidation et Partage»)}

(al comienzo del folio) Registré. No 7225

(al margen de la primera línea) portant la date de ce jour (siguen las rúbricas de validación)

(También al margen:) Fait expédition

Le trois octobre mil huit cent vingt sept, par-devant le dit $\mathrm{M}^{\mathrm{e}}$ Corbin, notaire à Paris, soussigné, commis à l'effet des présentes ainsi qu'il est énoncé au Procès Verbal qui précède,

Ont comparu

M. Michel Barré, assisté de $\mathrm{M}^{\mathrm{e}}$ Darlu, avoué à Paris, son conseil

375 Forqueray es notario de Paris y se puede encontrar noticia de ello en el Almanach del año 1828.

376 De este modo se indica que se anexa seguidamente otro documento.

Inquisidores contra la Inquisición

Hispania Sacra 55 (2003) 
Le M. Alexandre Fernández Ruidíaz, tous deux plus particulièrement dénommés au Procès Verbal du vingt cinq mai dernier, enregistré -dont la minute précèdeAgissant (sic) 377 dans les mêmes qualités que dans le Procès Verbal,

Lesquels ont dit qu'en exécution de l'ajournement pris par le Procès Verbal précédent, ils comparaissent à l'effet de prendre communication et lecture de l'état qu'a dû être dressé par $\mathrm{M}^{\mathrm{e}}$ Corbin des comptes, liquidation et partage de la succession de M. Jean Antoine Llorente.

Le dit $\mathrm{M}^{\mathrm{e}}$ Corbin leur ayant de suite donné lecture de cet état et liquidation, $\mathrm{M}$. Barré a déclaré l'approuver en toutes ses dispositions se réservant d'en poursuivre l'homologation devant le tribunal de première instance.

À l'égard de M. Ruidíaz, sans approuver ni contester le dit état de liquidation, il a déclaré qu'il ne s'opposait pas à ce que l'homologation en fût demandée.

Le dit état de liquidation écrit sur trois feuilles de papier au même timbre que le présent Procès Verbal est demeuré et annexé

(Se concluye esta plana recta del folio con las rúbricas de validación bien reconocibles como de Barré, Ruidias y Darlu) //

après avoir été signé et paraphé par les parties en présence du notaire soussigné.

Pour l'exécution des présentes, les parties élirent domicile en l'étude du dit $\mathrm{M}^{\mathrm{e}}$ Corbin. Dont acte fait et passé à Paris, en l'étude les jours mois et an ci dessus. Et ont les parties signé avec le dit $\mathrm{M}^{\mathrm{e}}$ Corbin après lecture faite.

(Siguen las firmas y rúbricas de:) Barré, Darlu, Ruidíaz, Corbin

Enregistré à Paris le onze octobre $1827, \mathrm{f}^{\mathrm{o}} 113, \mathrm{n}^{\circ}$ case 1-2-3-4-et 5, bureau ${ }^{378} 4^{\mathrm{e}}$. Reçu onze francs, dixième comprise, suivant le détail ci contre.

(Firmado y rubricado:) Cruvy

(Al margen, en columna, detalle de los derechos de registración:)

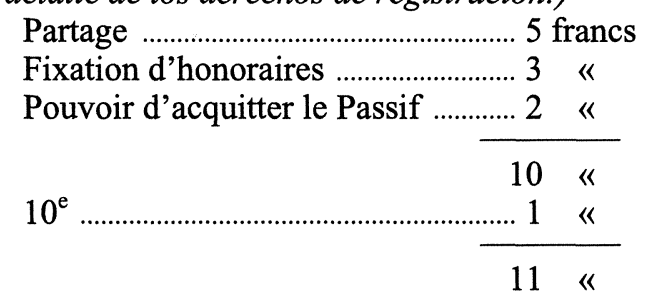

\footnotetext{
${ }^{377}$ Por agissants

${ }^{378}$ Interpreto la abreviatura $b^{a u}$ como bureau. Lo hago notar, porque mantengo todas las reservas que son del caso.
}

Inquisidores contra la Inquisición Hispania Sacra 55 (2003) 
Liquidation et partage de la succession de M. Jean Antoine Llorente, homme de Lettres, espagnol d'origine

(El documento se extiende sobre papel timbrado. Los timbres van sobre las páginas rectas de los tres primeros folios)

Fait expédition

Ces opérations seront dressées par $\mathrm{M}^{\mathrm{e}}$ Pierre Corbin, notaire à Paris, soussigné, commis à cet effet, tant par jugement rendu en la première chambre du Tribunal de première instance du Département de la Seine, le dix février mil huit cent vingt sept, enregistré, que par l'ordonnance de renvoi rendue le dix sept mai dernier, par M. Naudin, l'un des juges au même Tribunal, nommé pour les dites opérations.

Ces liquidation et partage auront lieu entre

$1^{\circ}$ Demoiselle Antoinette Elisabeth (sic) Llorente, mineure, demeurant à Paris, rue du Dauphin, $\mathrm{n}^{\circ} 16$,

fille naturelle légalement reconnue de $\mathrm{M}$. Llorente et, en cette qualité, ayant droit à sa succession pour les trois quarts en vertu de l'article 757 du Code Civil, au moyen de ce qu'elle concourt avec un cousin du défunt; la dite mineure Llorente représentée par M. Michel Barré, employé au Trésor Royal, demeurant à Paris, rue neuve Saint-Roch, $\mathrm{n}^{\circ}$ 8 , son tuteur.

$2^{\circ}$ Et M. Alexandre Fernández Ruidíaz, négociant, demeurant à Paris, rue Notre Dame des Victoires, $n^{\circ} 40$, seul héritier de $M$. Llorente, son cousin, et ayant droit à sa succession pour l'autre quart, ainsi qu'il résulte de l'inventaire et de l'acte rectificatif de cet inventaire, qui sont tout ci-après relatés.

Pour l'intelligence de ces opérations, elles seront précédées des observations suivantes.

Observations Préliminaires

Première Observation

Décès de M. Llorente. Inventaire. Vente d'une partie du mobilier

M. Llorente était venu se fixer à Paris en l'année mil huit cent douze ${ }^{379}$; en mil huit cent vingt trois, il retourna en Espagne, et il mourut à Madrid le cinq février de la même année.

(Siguen las rúbricas de validación de:) Corbin, Cruvy

(Sobre el margen izquierdo se hace la siguiente mención notarial acerca del presente documento:)

Signé et paraphé en présence du notaire à Paris, soussigné et annexé à la minute du procès verbal passé devant lui aujourd'hui trois octobre mil huit cent vingt sept. (Fir-

379 Recuérdese que Llorente sólo entró en Francia en 1813. Y no obtuvo licencia hasta bastante tiempo después para trasladarse a vivir en París.

Inquisidores contra la Inquisición Hispania Sacra 55 (2003) 
man y rubrican seguidamente al texto de la mención:) Barré, Darlu, Ruidiaz, Corbin, Morisseau $380 / /$

(al margen superior izquierdo se lee la siguiente mención notarial:) mil huit cent vingt $\operatorname{six}^{381}$ (Y siguen los «paraphes» de validación de Corbin, Morisseau yCruvy. Seguidamente continúa el tenor de la «première observation»)

L'inventaire des biens qu'il possédait en France fut fait par $\mathrm{M}^{\mathrm{e}}$ Marchoux, prédécesseur immédiat du dit $\mathrm{M}^{\mathrm{e}}$ Corbin qui en a gardé la minute, et son collègue, le neuf juin suivant, à la requête de $\mathrm{M}$. Ruidíaz, qui y a agi comme seul et unique héritier de $\mathrm{M}$. Llorente, son cousin germain.

M. Ruidíaz a depuis déclaré qu'il n'entendait prendre cette qualité que sous bénéfice d'inventaire, suivant un acte fait au Greffe du Tribunal de Première Instance de Paris le vingt quatre septembre dernier.

Le mobilier prisé en cet inventaire, à l'exception de la bibliothèque, a été vendu après affiches et publications par le ministère de M. Déa ${ }^{382}$, commissaire priseur à Paris, suivant Procès Verbal en date dix neuf août mil huit cent vingt trois, enregistré, dont le produit s'en est élevé à la somme de trois cent six francs dix neuf centimes, déduction faite de tous frais ${ }^{383}$.

Quant à la bibliothèque, M. Ruidíaz en resta dépositaire jusqu'au moment où elle a été vendue ainsi qu'on le verra ci-après.

Deuxième Observation

Pétition d'hérédité de la part de la mineure Llorente et rectification de l'inventaire en sa faveur

Ainsi qu'on vient de le dire, l'inventaire après le décès de $\mathrm{M}$. Llorente a été fait à la requête de $M$. Ruidíaz, comme seul héritier; mais il existait un enfant naturel de $M$. Llorente légalement reconnu, Antoinette Eliza Llorente, née de lui et de Françoise Joséphine Houllier, demeurant à Paris, ainsi qu'il résulte de l'acte de naissance de cet enfant, dressé sur les registres de l'état civil de la Mairie du premier arrondissement de Paris, le vingt trois septembre mil huit cent vingt, sur la déclaration de M. Llorente luimême, et duquel acte un extrait délivré par le Maire de cet arrondissement le dix septembre mil huit cent vingt-un, est demeuré ci-annexé après que dessus il en a été fait mention par le notaire soussigné.

Dans l'intérêt de sa pupille et par exploit de Couturier, huissier à Paris, en date du quatorze septembre mil huit cent vingt six, enregistré, $M$. Barré ci dessus nommé, fit sommation à $M$. Ruidíaz de se trouver le seize du dit mois de septembre en l'étude du dit $\mathrm{M}^{\mathrm{e}}$ Corbin, à l'effet de consentir la rectification de l'inventaire sus daté.

\footnotetext{
${ }^{380}$ A Morisseau se le encuentra en el Almanach Royal de 1828, p. 787, en la lista de los notarios

381 Señala, según parece, a la atención del lector que el dato se había considerado ya en el año anterior durante el procès verbal de septiembre de 1826.

382 Déa aparece asimismo en el Almanach de 1828 entre los comissaires-priseurs-vendeurs

383 En el documento se hallan aquí dos líneas en blanco y rayadas de un margen a otro con sendos
} de París. trazos ondulados. 
//

M. Ruidíaz, pour satisfaire à cette sommation, se présenta le jour indiqué par-devant le dit $\mathrm{M}^{\mathrm{e}}$ Corbin et, après avoir pris connaissance de l'acte de naissance de la mineure Llorente, déclara ne pas s'opposer à la rectification demandée, sous toutes réserves des droits de qui il appartiendrait, ainsi qu'il résulte du Procès Verbal qui en a été dressé le même jour, en suite de l'inventaire.

\section{Troisième Observation}

Vente de la bibliothèque

La bibliothèque que $M$. Ruidiaz avait conservé a été vendue en présence et du consentement de M. Barré, par le ministère de M. Gallimard ${ }^{384}$, commissaire priseur à Paris, suivant Procès Verbal en date au commencement du premier février mil huit cent vingt sept; le produit net de cette vente s'est élevé à la somme de dix huit cent trente soixante six francs quatre vingt quinze centimes, déduction faite des frais, ainsi qu'il résulte 385 du compte que $M$. Gallimard en a rendu le vingt six du dit mois de février mil huit cent vingt sept, dont la minute enregistrée est ensuite de celle du Procès Verbal de vente.

Quatrième Observation

Compte de M. (sic) Marchoux

M. (sic) Marchoux ancien notaire à Paris a touché les deux semestres qui ont suivi le décès de $\mathrm{M}$. Llorente, des arrivages des rentes en son nom; sur cette recette, il a avancé la somme de cent cinquante francs à la mineure Llorente, et il a retenu les frais d'actes qui lui étaient dûs.

Son compte est dressé de la manière suivante.

Les deux semestres de rente touchés par $\mathrm{M}^{\mathrm{e}}$ Marchoux s'élèvent à six cents francs, ci

$(+)$ 600. «

Sur cette somme $\mathrm{M}^{\mathrm{e}}$ Marchoux a retenu pour frais d'actes à lui dûs par la succession Llorente, suivant son mémoire approuvé par M. Ruidíaz et M. Barré, celle de cent quatre vingt-dix francs quarante-cinq centimes, ci

$(-) 190.45 \ll$

Et il a avancé à la mineure Llorente, suivant les quittances de M. Barré, cent francs le dix novembre mil huit cent vingt six, et cinquante francs le seize mars mil huit cent vingt-sept, ci $(-) 150$. «

Total à déduire 340.45. « $-.340 .45 \ll$

$259.55 \ll$

(La plana concluye con las rúbricas de validación reconocibles como de Corbin, Cruvy) $/ 1$ 259 francs, 55 centimes.

${ }^{384}$ Aparece en el Almanach de 1828 entre los commissaires-priseurs.

${ }^{385} \mathrm{El}$ texto repite qu'il résulte

Inquisidores contra la Inquisición

Hispania Sacra 55 (2003) 
En sorte que ( sic $\left.^{386}\right)$ M. Marchoux n'est pas comptable que de deux cents cinquante neuf francs cinquante centimes, ci $259 \mathrm{f}, 55$.

Cinquième Observation

Demande en partage formée par M. Barré

Sur la demande en partage formée par M. Barré, est intervenu au Tribunal de Première Instance de Paris le jugement du six février dernier déjà énoncé, qui a ordonné que par-devant $\mathrm{M}^{\mathrm{e}}$ Naudin ${ }^{387}$, l'un des Juges au dit Tribunal -lequel renverrait les parties devant $\mathrm{M}^{\mathrm{e}}$ Corbin notaire-, il serait procédé au compte, liquidation et partage de la succession de $\mathrm{M}$. Llorente; et en exécution de l'ordonnance de renvoi rendue par $\mathrm{M}^{\mathrm{e}}$ Naudin le dix sept mai dernier, le dit $\mathrm{M}^{\mathrm{e}}$ Corbin a procédé, ainsi qu'il suit, aux opérations qui lui ont été confiées.

\section{Masse Active}

La masse active se compose

$1^{\circ}$ De la somme de trois cent six francs dix neuf centimes, produit de la vente du mobilier meublant, fait immédiatement après le décès de $M$. Llorente, ci

306.19

$2^{\circ}$ De celle de mille huit cent soixante six francs quatre-vingt-quinze centimes, restant net de la vente de la bibliothèque, déduction faite des frais, ci $1.866,95$

$3^{\circ}$ De douze mille deux cent seize francs, formant le capital de rente perpétuelle sur l'Etat, cinq par cent consolidés, existant au nom de $\mathrm{M}$. Llorente et compris en quatre inscriptions au grand livre de la Dette Publique, l'une de cent quatre-vingt-dix-sept francs, $\mathrm{N}^{\circ} 36170$; la seconde de trois cent trois francs, $\mathrm{N}^{\circ} 36200$; et les deux autres de cinquante francs chacune, $\mathrm{N}^{\circ} 40383$ et 41140 , ci $12.216 \ll$ $4^{\circ}$ De deux mille quatre cents francs, montant des arrivages de ces rentes dûs par l'État depuis le vingt-deux septembre mil huit cent vingt-trois jusqu'au vingt-deux septembre dernier $2.400 \ll$

$5^{\circ}$ Des cent cinquante francs qui ont été avancés à la mineure Llorente par $\mathbf{M}^{\mathrm{e}}$ Marchoux ainsi qu'on le voit dans la quatrième observation, et dont elle fait le rapport, ci ....... 150 « $6^{\circ}$ Et de deux cent cinquante neuf francs cinquante cinq centimes, formant le reliquat du compte rendu par $\mathrm{M}$.

. (suma total de las cantidades consignadas hasta aqui en la masa activa: ) 16.939 f. 14 //

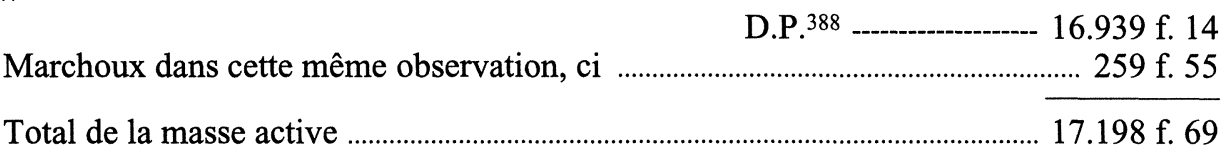

\footnotetext{
386 Por de sorte que o en sorte de que

387 Aparece en el Almanach entre los jueces miembros del Tribunal de première instance de Paris.

388 Dernière Page, es decir, suma de la página anterior.
} 


\section{Masse Passive}

La majeure partie du passif se compose des sommes ci-après, qui ont été acquittées par M. Ruidíaz, soit comme mandataire de M. Llorente et de son vivant ${ }^{389}$, soit comme ayant eu depuis son décès la gestion des affaires de la succession; et à l'appui des paiements par lui faits, M. Ruidíaz a produit des renseignements, notes et quittances qui les justifient; ces dépenses se composent des articles ci-après.

Montant des paiements faits par M. Ruidíaz pour compte de la succession de feu Llorente, depuis son départ de Paris, et antérieurement

(1822, diciembre)

Payé le quatorze décembre mil huit cent vingt-deux, pour un sac de voyage acheté le jour du départ de Paris de M. Llorente, trois francs cinquante centimes, ci... 3 f. 50 Payé le même jour pour un porte-feuille en maroquin ${ }^{390}$, sept francs, ci .. 7 « Payé le même jour pour quelques petits objets de voyage, deux francs trente centimes,

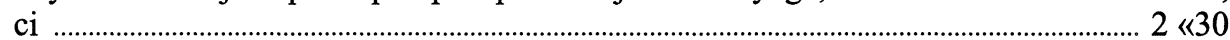
Payé le même jour pour quatre paires de bas ${ }^{391}$ en coton noir, vingt deux francs, ci ...... 22 « Payé le même jour pour deux paires de bas ${ }^{392}$ en soie noire, quatorze francs, ci ..... 14 « Payé le même jour pour une casquette ${ }^{393}$ de voyage en peau fine, vingt deux francs ..... 22 « Payé le même jour pour arrhes ${ }^{394}$ de deux places à la diligence pour Bordeaux, soixan-

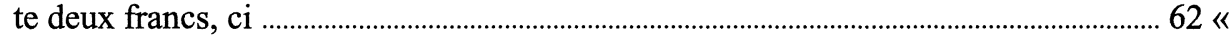

Payé le dix sept du même mois à M. Sepé pour un toupet ${ }^{395}$, vingt francs, ci .......... 20 «

Payé le vingt-un du même mois, pour un compte de relieur de livres ${ }^{396}$, douze francs soixante quinze centimes, ci $12 \ll 75$

Payé le même jour à $\mathrm{M}$. Fernel, pour billet à l'ordre ${ }^{397}$ du vingt-cinq octobre, cent francs, ci $100 \ll$

Payé le vingt-trois du même mois à Madame Houlier, de l'ordre de M. Llorente, cinquante francs, ci ... $50 \ll$

$315 \ll 55$

(concluye esta plana con las rúbricas de validación reconocibles como de Corbin y Cruvy) /l

\footnotetext{
389 Mientras vivía.

390 Tan significativo era el portafolios de marroquinería que el término maroquin -por sí solo- ya se usa en francés para indicar una cartera ministerial: obtenir un maroquin.

${ }^{391}$ Medias negras de algodón

392 Medias negras de seda

393 Gorra de viaje

394 Adelanto para dos billetes de diligencia.

395 Una media peluca para la parte superior de la cabeza.

396 Factura del encuadernador.

397 Un pagaré.

Inquisidores contra la Inquisición

Hispania Sacra 55 (2003)
} 
D.P.

315 f. 55 c.

Payé le même jour de l'ordre de M. Llorente, un bon ${ }^{398}$ de M. Emmanuel Llorente du vingt-cinq novembre, soixante francs, ci ......................................................................... 60 « Payé le même jour un autre bon du vingt-cinq décembre, soixante francs, ci ........... 60 «

(1823, enero)

Payé le premier janvier mil huit cent vingt trois à Madame Houlier trois francs, ci .......... 3 « Payé le même jour à $\mathrm{M}$. Théault, suivant ordre de $\mathrm{M}$. Llorente, cinquante francs, ci ..... 50 « Payé le même jour a M. Joachim, aussi suivant ordre de M. Llorente, dix francs, ci ...... 10 «

Payé le dix du même mois à M. Santibánez, pour corrections et traductions d'ouvrages, quatre-vingt-un francs, ci $81 \ll$

Payé le treize du même mois à Madame Houlier mois courant, soixante quinze francs, ci $75 \ll$

Payé le quinze du même mois à $\mathrm{M}$. Fernel un billet de $\mathrm{M}$. Llorente du vingt octobre, cent francs, ci $100 \ll$

Payé le vingt-huit du même mois à Madame Houlier deux francs, ci $2 \ll$

Payé le trente-un du même mois à $\mathrm{M}$. Chovel tailleur ${ }^{399}$, pour fournitures faites à $\mathrm{M}$. Llorente, deux cent vingt-deux francs, ci $222 \ll$

(1823, febrero)

Payé le quatre février de la même année, à Madame Houlier, pour sa dépense cent francs, ci $100 \ll$

Payé le six du même mois à M. Santibánez, pour corrections d'après convention, qua-

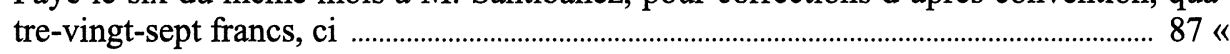

Payé le douze du même mois à Madame Houlier, pour sa dépense en frais de maladie, cent francs, ci $100 \ll$

\footnotetext{
398 Un bono: título de deuda expedido y firmado de ordinario por un ente público; o, también, por un simple particular en orden a garantizar dentro de un plazo determinado un pago que se retrasa de mutuo acuerdo.

${ }^{399}$ Sastre. Llama la atención la magnitud de la suma gastada en fournitures -aderezos, complementos, cosas hechas por el sastre o cortador con la tela que se le lleva-. Tal vez aquí Llorente está pagando algunos regalos. De hecho en su casa de París -visto el ajuar del inventaire- no aparecen cosas que justifiquen tales gastos. Pudo llevárselas a Madrid metidas en los baúles que se le enviaron tras su precipitado viaje. Pero, en cualquier caso, queda fuera de cualquier elucubración la elevada suma pagada al sastre.
} 
Payé le treize du même mois à Madame Houlier, pour solde de janvier, aussi (?) cinq francs, ci

Payé le même jour à la même, pour sa dépense, cinquante francs, ci ........................... 50 «

Payé le même jour aussi à la même, mois de février, quatre francs .............................. 4 «

Payé le même jour, pour frais d'emballage de divers objets appartenant à M. Llorente, et une malle pour M. Guttiérrez (sic)son secrétaire, quarante-un francs, ci ............... 41 « Payé le même jour à la direction de la Revue Encyclopédique pour diverses exemplaires de la notice sur $\mathrm{M}$. Llorente, quarante francs, ci $40 \ll$ (1823, marzo)

Payé le trente mars de la même année à Madrid, à $\mathrm{M}$. Gutiérrez, pour son entretien et pour le mois de février, cinquante francs, ci

(1823, abril)

P.D.

Payé le premier avril de la même année, pour solde du comte $\left(s i c^{400}\right)$ de M. Llorente avec M. Sarvy de Bayonne, arrêté le cinq mars, cinq cent soixante neuf francs vingt centimes, ci $569 \ll 20 \mathrm{c}$

Payé le même jour à $M$. Fernel pour solde de son compte avec M. Llorente, et suivant l'ordre de ce dernier, quatre cent soixante deux francs cinquante centimes, ci ....... 462 «50 c Payé a M. Gutiérrez, secrétaire de M. Llorente, pour ses appointements des mois de mars et avril, cent francs, ci $100 \ll$

(1823, mayo)

Payé le trois mai suivant à Madame Houlier, pour sa dépense, cent francs, ci ....... 100 « Payé le même jour a la même, avril et mai, huit francs, ci

(1823, junio)

Payé le vingt juin suivant, pour loyer du premier janvier au premier octobre, de l'appartement rue du Faubourg Saint Honoré $n^{\circ} 47$, quatre cent quatre vingt-seize francs cinq centimes, ci $496 \ll 05 \mathrm{c}$

Payé le même jour pour contributions de l'année, trente-un francs soixante centimes,

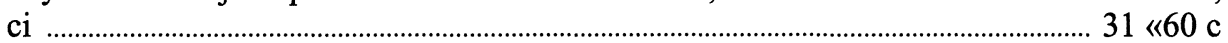
Payé le même jour, pour apposition des scellés, cinq francs cinquante centimes,

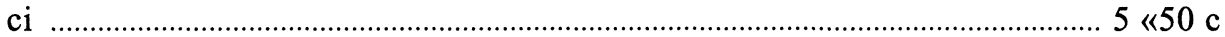
Payé le même jour, pour garde des scellés du dix sept février au sept avril, soixante six

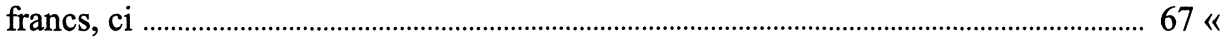
Payé le même jour, pour garde des scellés du sept avril au dix juin, soixante quatre francs, ci $64 \ll$ Payé le même jour a M. le Juge de Paix, suivant mémoire, cent douze francs quarante centimes, ci $112 \ll 40 \mathrm{c}$

400 Por compte. Saldo de cuenta. Se trata de un pago para satisfacer el saldo negativo y liquidar la cuenta (arrêter le compte).

Inquisidores contra la Inquisición

Hispania Sacra 55 (2003) 
Payé le même jour, pour caisses et emballage des livres de la bibliothèque, cent seize francs quinze centimes, ci............................................................................................ Payé le même jour, pour achat de cordes et journée de trois hommes de peine ${ }^{401}$ qui ont descendu les livres, cinquante trois francs, ci ............................................................ 53 « Payé pour caisses d'occasion pour les livres en emballage, cinquante sept francs, ci ......57 « Payé aux garçons pour le placement des livres en magasin, le même jour quatorze francs cinquante centimes, ci $14 \ll 50 \mathrm{c}$ Payé pour transport des livres, paquets et planches, le même jour, et pour gratifications, trente francs, ci .................................................................................................. 30 « Payé à la portière le même jour, pour avoir nettoyé l'appartement, dix francs, ci ......... 10 « Payé le même jour à $M$. Delaunay libraire, pour quatre vacations á l'inventaire des livres de feu M. Llorente, quarante francs, ci $40 \ll$ Payé le même jour à M. Marchoux notaire, suivant

(Total de la página:)

(Concluye la plana con las rúbricas de validación reconocibles como de Corbin y Cruvy) /l

mémoire, cent soixante deux francs cinq centimes, ci

D.P. 3.792 f. $45 \mathrm{c}$ $162 \ll 05 \mathrm{c}$

Payé le trente juin suivant, à M. Gutiérrez, pour ses appointements mai et juin, cent francs, ci $100 \ll$

(1823, julio)

Payé le trente juillet suivant au même pour le mois courant cinquante francs, ci .... 50 «

(1823, agosto)

Payé le trente août suivant au même, aussi pour le mois courant, cinquante francs, ci .. 50 « Payé le même jour, suivant l'ordre de M. Llorente, un bon de M. Emmanuel Llorente, soixante francs, ci $60 \ll$

. (1823, septiembre)

Payé le trente septembre de la même année à $\mathrm{M}$. Herran, pour pareille somme comptée a M. Llorente, à son passage à Miranda, suivant lettre, cinquante francs, ci ............ 50 « Payé le même jour, à M. Gutiérrez, pour ses appointements des mois de septembre et octobre, cent francs, ci $100 \ll$

(1823, diciembre)

Payé le trente-un décembre suivant, au même pour les mois de novembre, décembre et janvier, cent cinquante francs, ci 150 «

401 Tres mozos de cuerda. 
(1824, agosto)

Payé le vingt-quatre août mil huit cent vingt quatre à $M$. Verdière, pour loyer des livres déposés chez lui, soixante-quinze francs, ci ................................................................. 75 « Payé le même jour, pour frais de transport des livres, vingt huit francs soixante quinze centimes, ci $28 \ll 75 \mathrm{c}$

\section{(1825, enero)}

Payé le vingt-cinq janvier mil huit cent vingt cinq, à $M$. Remon, entre les mains de $M$. Arnao, la somme de cent francs pour pareille somme qui lui était due pour loyer d'une chaise de poste de Bordeaux à Victoria ( sic $\left.^{402}\right)$, ci $100 \ll$ Payé le même jour à $M$. Poisson, pour réparations faites à l'appartement de feu $M$. Llorente, rue du Faubourg Saint-Honoré $n^{\circ} 47$, quarante neuf francs soixante cinq centimes, ci $49 \ll 65 \mathrm{c}$ Payé le même jour à Madrid, pour frais des funérailles de M. Llorente, suivant mémoire, sept-cent quatre- vingt-dix-sept francs vingt cinq centimes, ci $797 \ll 25 \mathrm{c}$

(1827, junio)

Intérêts à raison de cinq pour cent par an des sommes ci dessus, du jour de paiement au trente juin mil huit cent vingt-sept, mille quatre vingt francs dix centimes, ci $1.080 \ll 10 \mathrm{c}$

Ces intérêts sont dûs à Mr. (sic) Ruidíaz aux termes de l'article 2001 du Code Civil. Ports de lettres ${ }^{403}$ dans cette liquidation jusqu'à ce jour, deux cent vingt-huit francs soixante-dix centimes, ci $6.883 \mathrm{f.} 95 \mathrm{c}$ //

D.P. $6.883 \mathrm{f} .95 \mathrm{c}$

Payé pour frais de transport des livres chez M. Silvestre, emballage et cetera, cent quinze francs, ci .................................................................................................................... 115 « Payé à la direction de l'enregistrement, pour les droits de succession, quatre-vingt-dixsept francs quatre vingt-dix centimes, ci $97 \ll 90 \mathrm{c}$

Total des sommes payés par $\mathrm{M}$. $7.086 \ll 85 \mathrm{c}$

La masse passive se compose encore,

$1^{\circ}$ De la somme de deux cent vingt francs trente centimes, montant des frais réclamés par M. Darlu, pour la pétition d'hérédité formée par la mineure Llorente et la demande en partage, ci $220 \ll 30 \mathrm{c}$ $2^{\circ}$ Et de celle de trois cents francs trente centimes, pour le coût de la présente liquidation, compris deux expéditions et les frais de timbre et enregistrement, évalués à cent francs, ci $300 \ll$

Total de la masse passive $7.607 \ll 15 \mathrm{c}$

402 Por Vitoria

403 Port es el precio del transporte de una carta o de un paquete.

Inquisidores contra la Inquisición

Hispania Sacra 55 (2003) 
Balance

La masse active est de 17.198 f. $69 \mathrm{c}$

La masse passive est de 7.607 f. $15 \mathrm{c}$

Par tant, il reste dans la succession, la somme de 9.591 f. 54

Les trois quarts de cette somme revenant à la mineure Llorente sont de sept mille cent quatre-vingt-seize francs soixante-six centimes, ci

$7.193 \mathrm{f} .66$

Et le quart revenant â M. Ruidíaz est de deux mille trois cent quatre-vingt-dix-sept francs quatre-vingt-huit centimes, ci 2.397 f. $88 \mathrm{c}$ Ajoutant à ses droits la somme de sept mille six cent sept francs quinze centimes, montant de la masse passive qu'il a acquittée ou acquittera, ci . $.7 .607 \mathrm{f} .15 \mathrm{c}$

Ensemble $10.005 \mathrm{f} .03 \mathrm{c}$ $10.005 \mathrm{f} .03 \mathrm{c}$

On a un total égal à la masse brute de la somme de 17.198 f. $69 \mathrm{c}$

Abandonnements

Mineure Llorente

Pour fournir à la mineure Llorente les sept mille cent quatre-vingt-seize francs soixante-six centimes qui lui reviennent

Elle aura et il lui est abandonné, (concluye esta plana con las rúbricas de validación reconocibles como de Corbin y Cruvy) //

$1^{\circ}$. Trois cents francs à prendre dans les rentes portées article trois de la masse active, représentés par un capital de six mille huit cent huit francs au cours actuel, ci ....... 6.108 « $2^{\circ}$. La somme six cent soixante-seize francs onze centimes, à prendre dans les arrivages des rentes portées article quatre, ci $676 \ll 11 \mathrm{c}$ $3^{\circ}$. La somme de deux cent cinquante neuf francs cinquante cinq centimes, formant le reliquat de M. Marchoux, porté article six, ci $259 \ll 55 \mathrm{c}$ Enfin, la dite mineure confondra en elle-même les cent cinquante francs qui ont été 'touchés pour elle par M. Barré, ci $150 \ll$

Somme égale à ses droits 7.193 f. $66 \mathrm{c}$

\section{Ruidíaz}

Pour fournir à M. Ruidíaz les dix mille cinq francs trois centimes qui lui reviennent, Il lui est fait abandon

$1^{\circ}$. De la somme de trois cent six francs dix neuf centimes montant de la vente du mobilier porté article premier de la masse active, ci $306 \ll 19 \mathrm{c}$

$2^{\circ}$. De la somme de mille huit cent soixante six francs quatre-vingt-quinze centimes, produit de la vente de la bibliothèque portée article deux, ci $1.866 \ll 95 \mathrm{c}$ $3^{\circ}$. De trois cents francs à prendre dans les rentes portées article trois de la masse, représentés par un capital de six mille cent huit francs au cours actuel, ci $6.108 \ll$ 
$4^{\circ}$. Et de celle de dix sept cent vingt-trois francs quatre-vingt-neuf centimes à prendre dans les arrivages de rente portés article quatre, ci 1.723 f. 89 c

Somme égale à ses droits 10.005 f. $03 \mathrm{c}$

Jouissance

La mineure Llorente et $\mathrm{M}$. Ruidiaz jouiront et disposeront respectivement des sommes comprises en leurs abandonnements, à compter du vingt-deux septembre mil huit cent vingt sept.

Condition

La garantie ordinaire aura lieu telle qu'elle est de droit /l en fait de partage.

$\mathrm{M}^{\mathrm{e}}$ Corbin est autorisé à délivrer aux parties les certificats de propriété nécessaires pour faire immatriculer à leur nom les inscriptions abandonnées à chacune d'elles.

C'est ainsi que le tout a été dressé par le dit $\mathrm{M}^{\mathrm{e}}$ Corbin en sa qualité de notaire commis à cet effet, comme il a été expliqué.

$\mathrm{Au}$ moyen de tout ce qui précède, la succession de $\mathrm{M}$. Llorente se trouve liquidée et partagée, sous toutes réserves et sauf erreurs, omissions ou doubles emplois.

Fait et rédigé à Paris, le trois octobre mil huit cent vingt sept

(Hay una nota al margen que dice:) Approuvé le bâtonnement ${ }^{404}$. Deux lignes entières en blanc ${ }^{405}$ etc. Rayé dix mots comme nuls (y siguen tres rúbricas reconocibles como de Corbin, Morisseau y Cruvy)

(Siguen, por fin, las firmas y rúbricas de:) Morisseau, Corbin.

Enregistré à Paris le onze octobre 1827, folio $113, \mathrm{n}^{\circ}$ case 5 . Reçu un franc et dix centimes pour la dixième

(firma y rúbrica de:) Cruvy

\footnotetext{
404 Faire le bâton, se dice de los estudiantes que preparan su caligrafia con dos líneas paralelas que faciliten luego la regularidad de la escritura. Bâtonnement es una palabra usada aquí por el grefier y que tiene que ver con el bâton estudiantil. Se refiere sin duda a las diversas rectas que -cuando es oportuno-completan las líneas hasta el margen de la plana, para que no quede espacio en blanco, impidiendo así posibles añadiduras.

405 Ya se señaló en su lugar, Primera Observación ad finem
}

Inquisidores contra la Inquisición

Hispania Sacra 55 (2003) 


\section{C. Acta de nacimiento de Antoinette Elise}

Lorente (sic) Fait expédition ${ }^{406} \quad$ Enregistrement

(Impreso en ángulo superior izquierdo:)

No. 1 .

État Civil

(sigue a mano:) R-51, No-285

(Impreso en cabecera del folio:) Préfecture du Département de la Seine. Ville de Paris. (Hay dos timbres de 50 y de 75 céntimos respectivamente) (A mano:) $1^{\mathrm{er}}$ Mairie ( $y$ continúa el impreso) Extrait du Registre des Actes de Naissance de l'an (concluye aqui la letra impresa. El año va escrito a mano) 1820

Du vingt trois septembre mil huit cent vingt à deux heures un quart du soir

Par-devant nous, Claude Antoine Thory, adjoint au Maire du premier arrondissement de Paris, est comparu sieur Jean Antoine Lorente, homme de Lettres, âgé de soixante ans, demeurant rue du Faubourg $S^{t}$ Honoré $n^{\circ} 41$, lequel nous a présenté un enfant du sexe féminin, qu'il nous a déclaré être né de lui et de Dame Françoise Josephine Houllier, fruitière, âgée de trente trois ans, demeure susdite, le vingt un du présent à quatre heures du matin, les dites non mariés, auquel enfant naturel il a donné les prénoms de Antoinette Elisa.

La dite déclaration faite en présence des sieurs Jean Joseph Houllier, âgé de soixante quatre ans, menuisier ${ }^{407}$, demeurant à Bicètre, père de la mère de l'enfant, Joseph Philippe Houllier, fournier ${ }^{408}$, âgé de vingt neuf ans, passage de Venisse $n^{\circ} 4$, frère de la mère, et ont le père et les témoins signé avec nous après lecture faite.

Signé: Jean Antoine Lorente, Houllier, Houllier et Thory

Délivré pour extrait conforme, par Nous, Maire.

Paris le 10 septembre 1821

\footnotetext{
- 406 En efecto, el acta de nacimiento de Antoinette Elise transcrita es un "extrait authentique» («Un extrait -dice el Elsevier's Lexikon $\mathrm{n}^{\circ} 30$ - est une copie textuelle de certains éléments d'un document. - De même que la copie, l'extrait peut recevoir une marque d'autenticité. Il est alors dit: extrait authentique) du Registre des Actes de Naissance de l'an 1820. Este extrait authentique obra, en la Greffe de la notaría -como minuta adjuntada al expediente de sucesión- de la cual se hacen expediciones notariales a las partes. De ahí, la anotación fait expédition. Por la nota marginal validada por la firma y rúbrica de dos notarios -Corbin y Morisseau- adquiere rango de autenticidad. - De este extrait authentique se sacó el 25 de noviembre de 1872, en exécution de la loi de 12 février 1872 - promulgada para reparar los daños producidos por los incendios de la Commune en 1870- la reconstitution de l'Acte de Naissance de Antoinette Elisa Lorente (sic), expédié et collationné por Delapalme, notaire de Paris, que obra en el Archivo de la Préfecture du Département de la Seine, Ville de Paris, $1^{\text {ere }}$ Mairie, Registre des Actes de Naissance de 1820. Etat Civil, R-51, $\mathrm{n}^{\circ} 285$. También de este Acte reconstitué por Delapalme conservo copia, pero -como es natural- no añade nada a la ya transcrita. 407 Carpintero

408 Hornero
}

Inquisidores contra la Inquisición Hispania Sacra 55 (2003) 
(Firma ilegible. Hay un sello de la Mairie du premier arrondissement de Paris) (Al margen izquierdo de la primera página se lee) Annexé à l'état de liquidation et partage de la succession de $\mathrm{M}$. Llorente dressé par le notaire à Paris soussigné, commis à ces effets ce-jourd'hui, trois octobre mil huit cent vingt sept ${ }^{409}$.

(Siguen las firmas y rúbricas de) Corbin, Morisseau

(Acompaña también un sello de la «Mairie du premier arrondissement de Paris»)

(El documento concluye con la nota del registro: ) Enregistré à Paris le 10 septembre 1821 , fol. $173, \mathrm{~N}^{\circ}$. Case ---. Reçu cinq francs 50 centimes pour la dixième

(Hay firma y rúbrica del «huissier» del registro)

2.D. Extracto auténtico de las minutas que obran en la Escribanía del Tribunal Civil de Primera Instancia del Departamento del Sena ${ }^{410}$

17 mai 1827

(Dos timbres de 75 y 50 céntimos respectivamente)

Renvoi devant Notaire

Barré

G(reffe) R(egistre $)^{411}$

Extrait des minutes du Greffe du Tribunal Civil de première instance du Département de la Seine séant au Palais de Justice à Paris. L'an mil huit cent vingt sept et le jeudi dix-septième jour du mois de mai, une heure de relevée 412 .

En la Chambre du Conseil de la Première Chambre du Tribunal Civil de première instance du Département de la Seine

Et par-devant nous, Jean Charles Naudin ${ }^{413}$, juge au dit tribunal, commissaire

\footnotetext{
409 Hay otra nota marginal, de contenido análogo a la transcrita, que afirma que el presente extrait du Registre des Actes de Naissance estuvo anexada a un anterior Procés Verbal. Está tachada con gruesos bâtons y por eso su lectura no es totalmente posible.

$410 \mathrm{El}$ «Tribunal de Première Instance, séant au Palais de Justice», ha surgido de la «Cour Royale de Paris». Tiene por tanto un rango de principalidad. Está compuesto de 42 Jueces -entre los que se cuenta el Presidente-; 7 vicepresidentes; 10 jueces de instrucción, 14 jueces suplentes -4 de los cuales cumplen habitualmente funciones de jueces de instrucción-. Se divide en 7 cámaras (chambres) integradas cada una de ellas de 6 jueces y 2 suplentes. 5 de estas cámaras están dedicadas a asuntos civiles; la $6^{\mathrm{a}}$ y la $7^{\mathrm{a}}$ a asuntos de policía correccional. - Hay además ante este Tribunal un Procurador del Rey, 15 sustitutos del Procurador del Rey, un escribano jefe, siete escribanos oficiales jurados para el servicio de las audiencias, uno para la cámara del Consejo, uno para las ventas y transacciones «sub hasta», uno para los depósitos, y 14 para el servicio de los jueces de instrucción. Cfr. Almanach Royal 1828, p. 771

411 Resolución medianamente probable de las abreviaturas G. $R$.

412 Una de la tarde

413 Cfr. Almanach Royal 1828, p. 771.
}

Inquisidores contra la Inquisición

Hispania Sacra 55 (2003) 
(Al margen izquierdo de la página se leen las notas del costo de expedición de este «renvoi devant notaire»: )

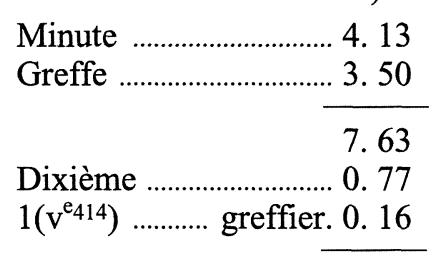

8. 56

(Seguidamente, también al margen izquierdo, se lee: ) Le dix neuf mai $1827 \mathrm{f}^{\circ} 46$, case 7. Reçus quatre francs, dixième compris pour droits de greffe. (firma y rúbrica de:) Maire

(A continuación, en el mismo margen):

D 8.56

1.50

3.75

0.14

0.95

14. 90

$20\left(v^{\mathrm{me}_{415}}\right)$

15. 10

(Por fin, en el ángulo inferior izquierdo se lee el número del documento y el nombre del peticionario: ) $\mathrm{n}^{\circ} 544$ Darlu

/I

en cette partie, assisté de maître Foutete ${ }^{416}$, commis greffier assermenté,

est comparu maître Pierre Louis Darlu, avoué en ce tribunal et celui du sieur Michel -Barré417, employé du Trésor Royal, demeurant à Paris, rue neuve Saint Roch, numéro huit -le dit sieur Barré agissant comme tuteur de la mineure Antoinette Llorente aux termes d'une délibération du conseil de famille de la dite mineure prise le six juillet mil huit cent vingt quatre sous la

414 Vingtième. Así lo leo, e interpreto que es un derecho a cobrar por el greffier. «Il y a vint «sous à la livre, et le sol pour livre était l'impot du vingtième prélevé sur la vente des marchandises». Gaston CAIROU, Le français classique. Lexique de la langue du XVII Siècle, Didier, Paris 1948, 804. -Sol y sou es lo mismo y siempre se pronuncian como sou. Sobre la importancia de una economía paralela basada en el sou, cfr. Guy THUILLIER, La monnaie en France au début du XXIX $X^{e}$ Siècle, Droz, Genève $1983,215-223,265-268$.

$415 \mathrm{Cfr}$. nota precedente.

416 Transcripción probable del apellido del greffier del Tribunal.

417 Abogado en este tribunal y celui, es decir, abogado también de M. Barré.

Inquisidores contra la Inquisición Hispania Sacra 55 (2003) 
//

(hay sendos timbres uno de 75 céntimos y otro de 50 céntimos a pagar en «sus») présidence du Juge de Paix du Canton de Neuilly-.

Lequel ${ }^{418}$ nous a dit que le sieur Barré a formé dans l'intérêt de sa pupille une demande en compte, liquidation et partage de la succession du sieur Jean Antoine Llorente contre le sieur Ruidíaz, son héritier légitime, demeurant à Paris, rue Notre Dame des Victoires, numéro quarante et que par un jugement rendu par défaut contre le dit sieur Ruidíaz le dix février dernier en la Première Chambre de ce Tribunal, il a été ordonné qu'il serait

//

procédé par-devant nous aux comptes, liquidation et partage de la dite succession et que nous renverrions les parties pour les opérations de détail devant maître Corbin notaire à Paris successeur de maître Marchoux qui a dressé l'inventaire, que le jugement a été signifié le deux mars dernier au sieur Ruidíaz qui n'y a point formé opposition.

Que le sieur Barré pour procéder en exécution du dit jugement nous a présenté les frais mai courant en requête tendante à obtenir l'auto-

//

risation d'appeler devant nous le sieur Ruidíaz pour voir renvoyer les parties devant maître Corbin.

Et que par notre ordonnance en date de huit du même mois, rendue au bas de la dite requête et dûment enregistrée, nous avons indiqué jour au dix-sept mai, mil huit cent vingt sept une heure de relevée pour le comparution ${ }^{419}$ des parties.

Qu'en vertu de la dite ordonnance et par exploit de sieur huissier audiencier par nous commis à cet effet en date

/l

du quatorze mai courant, le sieur Barré a fait faire sommation au sieur Ruidíaz de comparaître par-devant nous à les jour, lieu et heure pour voir renvoyer les parties devant maître Corbin.

Que le dit maître Darlu comparait au désir de cette sommation et qu'il requiert qu'il nous plaise donner défaut contre le sieur Ruidíaz en cas de non-comparution de sa part et, dans tous les cas, ouvrir le procès verbal de nos opérations et prononcer le renvoi dont il s'agit.

/l

Et a, le dit maître Darlu, signé -après qu'il nous a en représenté- notre ordonnance du huit mai courant et l'original de la sommation ci dessus datés, lesquelles lui ont été remises de suite par nous.

Signé Darlu sur et en pareil endroit de la minute des présentes.

Desquelles comparution dire et réquisition, nous, Juge commissaire, avons donné acte au dit maître Darlu.

Et, attendu que le sieur Ruidíaz ne s'est pas présenté ni personne pour

/I

418 Maître Darlu, que es quien comparece en primer término.

419 Comparecencia

Inquisidores contra la Inquisición

Hispania Sacra 55 (2003) 
lui, nous avons donné défaut contre le dit sieur Ruidíaz, avons déclaré ouvert le procès verbal des opérations qui nous sont déléguées par le jugement du dix février mil huit cent vingt sept et avons en outre renvoyé les parties devant maître Corbin, notaire à Paris, à l'effet de procéder devant lui comme il est ordonné aux articles huit cent vingt huit et suivants du Code Civil, et nous avons signé notre présent procès verbal avec le greffier.

Signé Naudin et

/I

(hay dos timbres: el de 75 y el de 50 céntimos «en sus» según la ley de 1816) Fautete $\mathrm{e}^{420}$

Enregistré à Paris le dix neuf mai mil huit cent vingt sept folio 46 case 7 . Reçus quatre francs -centimes dixième compris

Signé Maire

Collationné (rubricado por Gautier)

Pour expédition

(Firma y rúbrica de) Gautier

(Sigue inmediatamente el «Exploit» del Hussier Couturier)

L'an mil huit cent vingt sept, le vingt deux mai, à la requête du sieur Michel Barré, employé au Trésor Royal ${ }^{421}$, demeurant à Paris, rue neuve $\mathrm{S}^{\mathrm{t}}$ Roch $\mathrm{n}^{\circ} 8$, lequel fait élection de domicile en l'étude de $\mathrm{M}^{\mathrm{e}}$ Darlu, avoué près le Tribunal de première instance de la Seine, sise à Paris rue de Louvois $n^{\circ} 4$;

Le dit sieur Barré, agissant au nom et comme tuteur de la mineure Antoinette Elisa Llorente, fille naturelle reconnue du feu sieur Jean Antoine Llorente, j'ai -Gabriel Marie Couturier, huissier près le Tribunal Civil de première instance du Département de la Seine séant á Paris rue de la Jussienne $n^{o} 11$, patente de 29 marc d'or $n^{o} 293^{e}$ classe, soussignét 422

/l

ai signifié et, avec celle des présentes, laissé copie au sieur Alexandre Fernández Ruidí$\mathrm{az}$, négociant, demeurant à Paris, rue Notre Dame des Victoires $\mathrm{n}^{\circ} 40$, en son domicile, en parlant à-u portier de la dite maison ainsi déclarée ${ }^{423}$, d'un procès verbal dressé le dix sept mai présent mois, par Monsieur Naudin, juge au Tribunal de première instance de la Seine, lequel contient une ordonnance qui renvoie le sieur Barré, au noms ${ }^{424}$, et le sieur Ruidíaz, devant $\mathrm{M}^{\mathrm{e}}$ Corbin, notaire à Paris, pour procéder devant lui aux compte,

\footnotetext{
${ }^{420}$ Transcripción muy probable del apellido del greffier.

${ }^{421}$ Estas palabras, employé au Trésor Royal, son añadidas al margen: como siempre con las rúbricas de validación.

422 Las palabras en cursiva van escritas en el documento no de mano del greffier, sino de mano del propio huissier Couturier. El greffier ha extendido el documento que luego ha sido completado por el huissier.

${ }^{423}$ Lo que va en cursiva es de la mano de Couturier. Habla del portier de la maison, aunque sabemos que era una portière.

${ }^{424}$ Lectura probable.
} 
liquidation et partage de la succession du sieur Jean Antoine Llorente à ce que du contenus au dit procès verbal le sus-nommé n'ignore.

Et à même requête, j'ai -huissier susdit- fait sommation au dit sieur Ruidíaz de comparaître le vingt cinq mai courant, heure de midi, en l'étude de $\mathrm{M}^{\mathrm{e}}$ Corbin, notaire à Paris, sise en cette ville, rue Vivienne $\mathrm{n}^{\circ} 6$, à $1^{\prime}$ effet de procéder devant cet officier, aux compte, liquidation et partage de la succession du sieur Jean Antoine Llorente, ainsi qu'il est expliqué aux articles 828 et suivants du Code Civil; lesquelles opérations ont été commises $^{425}$ au dit $\mathrm{M}^{\mathrm{e}}$ Corbin, par un jugement du Tribunal de première instance de la Seine, en date du dix février 1827; déclarant au sieur Ruidíaz que, faute par lui du comparaitre aux dits lieu, jour et heure, il sera donné défaut contre lui, et que le requérant se pourvoira ensuite ainsi qu'il avisera.

À ce que le sus-nommé n'en ignore, je lui ai en outre laissé copie du présent exploit, dont le coût est de sept francs 25 centimes.

Deux mots rayés nuls

(Al margen izquierdo:)

orig $^{1}$

copie

2.

$\mathrm{C}^{\mathrm{ie}}$.d.p. 0.50

Timb

1. 50

enreg $^{\mathrm{e}}$

\section{25}

(Sigue la firma y rúbrica de:) Couturier

Enregistré à Paris le vingt trois mai 1827. Reçu deux frans 20 centimes (Firma ilegible y rúbrica del contador del registro)

Annexé à la minute du procès verbal d'ouverture de la liquidation de la succession de $\mathrm{M}$. Llorente dressé par $\mathrm{M}^{\mathrm{e}}$ Corbin, notaire à Paris, soussignés ${ }^{426}$ commis à cet effet en date du vingt cinq mai mil huit cent vingt sept.

(Firma y rúbrica de:) Forqueray, Corbin

2.E. Acta de entrega por parte de Michel Barré -Tutor de la niña Antoinette Elise Llorente- de la copia auténtica del Juicio desarrollado en el Tribunal de Primera Instancia del Departamento del Sena, el 4 de enero de 1828

${ }^{425}$ La palabra commises sustituye - mediante nota al margen y con las debidas rúbricas de validación- dos palabras tachadas en el tenor del documento.

426 Parece que vastaba con el singular soussigné. Pero el plural concuerda con la realidad de que son dos los que firman.

Inquisidores contra la Inquisición

Hispania Sacra 55 (2003) 
(Membrete a imprenta, que dice:) Corbin $\mathrm{N}(\mathrm{otai})^{\mathrm{re}}$

$\mathrm{N}^{\circ} 7982$ Registré

(Se advierte la presencia de un sello, incompleto, en el que se lee) Royal

Et le seize janvier mil huit cent vingt huit par-devant $\mathrm{M}^{\mathrm{e}}$ Pierre Corbin et son collègue notaire à Paris, soussignés

Fut présenté

M. Michel Barré, employé au Trésor Royal, demeurant à Paris, rue neuve $\mathrm{S}^{t}$ Roch $\mathrm{n}^{\circ} 8$ ci-devant ${ }^{427}$ et actuellement rue du Dauphine $\mathrm{n}^{\circ} 14$,

Lequel a déposé pour minute à dit $\mathrm{M}^{\mathrm{e}}$ Corbin la grosse $\mathrm{e}^{428} \mathrm{~d}$ 'un jugement rendu en la chambre du Conseil de la première Chambre du Tribunal civil de première instance du Département de la Seine le quatre de ce mois, enregistré, contenant homologation du Procès Verbal de liquidation de la succession de M. Jean Antoine Llorente, dressé par le dit $\mathrm{M}^{\mathrm{e}}$ Corbin le trois octobre mil huit cent vingt sept, enregistré et annexé à un acte reçu par le dit $\mathrm{M}^{\mathrm{e}}$ Corbin le même jour, dont la minute enregistrée est une de celles qui précèdent.

En conséquence cette grosse, ensuite de laquelle est la signification qui en a été faite, à la requête du comparant, à $\mathrm{M}$. Alexandre Fernández Ruidíaz, négociant, demeurant à Paris rue Notre Dame des Victoires $\mathrm{n}^{\circ}$ 40, par exploit de Couturier, huissier à Paris, in date du douze de ce mois, est demeure ci-jointe, après avoir été certifié véritable, signé par le comparant et revêtue d'une mention d'annexe

Dont acte

Fait et passé à Paris en l'étude

Les dits jour, mois et an sus-indiqués et a le comparant signé avec les notaires, après lecture

(Firmas y rúbricas de:) Barré, Leroux, Corbin

(Está también presente la rúbrica de:) Cruvy

\section{F. Acta de «Homologation» ${ }^{429}$}

4 janvier 1828

(Están los dos timbres legales) Homologation

Llorente

G(reffe) R(egistr)é 430

(Continuando siempre al margen izquierdo se lee:)

\footnotetext{
427 Anteriormente. Barré, por lo tanto había mudado de domicilio.

428 Grosse: copia o traslado de un documento público.

429 Homologation es tanto como la confirmación judicial o administrativa de los resultados finales de un proceso

430 Interpretación medianamente probable de la abreviatura G.R.
}

Inquisidores contra la Inquisición Hispania Sacra 55 (2003) 


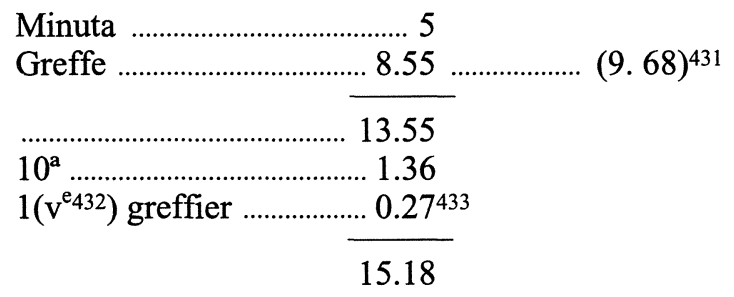

(Otra nota al margen dice:)

Le huit janvier 1828 fol.6 case $1^{\text {ère }}$. Reçu pour Greffe neuf francs 68 centimes, tout compris. (Firma y rúbrica de:) Maire

(Otra anotación al margen recoge:)

D $\quad 15.18$

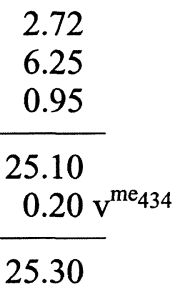

(Por fin, en el ángulo inferior izquierdo se lee el número del documento y el nombre del peticionario: ) $\mathrm{n}^{\circ} 228$. Darlu

(El tenor del documento es como sigue:)

Charles, par la grâce de Dieu, Roi de France et de Navarre;

A tous ceux qui ces présentes verront,

Salut

Le Tribunal Civil de première instance du Département de la Seine, séant au Palais de Justice à Paris, a rendu en la Chambre du Conseil de la première Chambre, le jugement dont la teneur suit:

Sur le rapport

/I

fait en la Chambre du Conseil de la première Chambre du Tribunal Civil de première instance du Département de la Seine par monsieur Naudin, l'un des juges de celui, de

${ }^{431}$ Como se ve seguidamente, este es el total recibido por la Greffe. El paréntesis no es mío: está en el documento.

432 Interpretación probable. Cfr. nota análoga en documento anterior.

${ }^{433}$ Como se ve se trata en realidad de un 20 por ciento de la décima Cfr. Un asiento semejante en las cuentas del documento del 17 mai, Renvoi devant Notaire.

${ }^{434}$ Recuérdense notas análogas anteriores

Inquisidores contra la Inquisición

Hispania Sacra 55 (2003) 
la requête présenté par le sieur Michel Barré, signée par maître Darlu, avoué, et dont suit la teneur:

(Rapport de Barré/Darlu) «A messieurs les Président et Juges composant le Tribunal Civil de première instance du Département

/I

(los dos timbres legales) de la Seine, séant au Palais de Justice à Paris.

Monsieur Michel Barré, employé au Trésor Royal, demeurant à Paris, rue neuve Saint Roch numéro huit, agissant au nom et comme tuteur de Antoinette Elisabeth (sic) Llorente, fille naturelle, mineure, du sieur Jean Antoine Llorente, décédé et de la demoiselle Françoise-Josephine Houillier (sic), nommé à ces fonctions qu'il a acceptées, suivant délibération de conseil de famille de la dite

(Hay al margen izquierdo una mención notarial que se refiere al tenor de la presente requête, $y$ que dice:) Certifié véritable signé et déposé pour minute a $\mathrm{M}^{\mathrm{e}}$ Pierre Corbin l'un des notaires à Paris sous-signés, par acte passé devant lui et son collègue a jourd'hui seize janvier mil huit cent vingt huit.

(Siguen las firmas y rúbricas de:) Barré, Corbin, Leroux

//

mineure, reçue par monsieur le Juge de Paix du Canton de Neuilly, arrondissement de Saint Denis, Département de la Seine, le six juillet mil huit cent vingt-quatre, duement $\left(\right.$ sic $\left.{ }^{435}\right)$ enregistrée;

ayant le dit sieur Barré maître Darlu pour avoué, a l'honneur de vous exposer:

que par Jugement rendu en la première Chambre du Tribunal Civil de première instance du Département de la Seine le dix février mil

/I

(dos timbres legales) huit cent vingt-sept, enregistré, entre lui et le sieur Alexandre Fernández Ruidíaz, demeurant à Paris rue Notre Dame des Victoires, numéro quarante, héritier légitime de feu sieur Llorente, par défaut contre le dit sieur Ruidíaz, le Tribunal a ordonné qu'il serait procédé aux opérations de comptes, liquidation et partage de la succession du sieur Jean Antoine Llorente par-devant monsieur Naudin, juge en ce Tribunal, que le Tribunal a commis à cet effet; lequel renverrait pour les opérations de

$.1 /$

partage devant maître Corbin, notaire à Paris, dépens réservés; et que par ordonnance rendue sur requête le dix-sept mai mil huit cent vingt-sept, duement (sic) enregistrée, monsieur Naudin a déclaré ouvert le Procès Verbal des opérations à lui déléguées par le sus-dit jugement et a renvoyé les parties devant maître Corbin à l'effet de procéder devant lui, ainsi qu'il est ordonné par les articles huit cent vingt huit et suivants, du Code Civil.

Que suivant procès verbal dressé par

II

(dos timbres legales) le dit maître Corbin et son collègue notaires à Paris, les vingtcinq mai et trois octobre mil huit cent vingt sept, il a été procédé, en exécution de la dite ordonnance, à la liquidation de la succession du feu sieur Llorente; et que cet acte

435 Por dûment

Inquisidores contra la Inquisición Hispania Sacra 55 (2003) 
de liquidation est régulier en la forme, et juste au fonds; que il s'agit aujourd'hui de le faire homologuer;

Pour quoi il requiert qu'il vous plaise, messieurs, vu l'article neuf cent quatre-vingt et un du //

du $\left(\operatorname{sic}^{436}\right)$ Code de Procédure Civile, homologuer sur ce rapport de monsieur Naudin, juge commissaire, le dit acte de liquidation pour être exécuté dans toutes ses parties selon sa forme et teneur; et l'autoriser à employer en frais privilégiés de poursuite de liquidation ceux par lui faits, y compris les dépens réservés par le jugement du dix février mil huit cent vingt-sept pour être remboursé du montant d'iceux ${ }^{437}$ par privilège, sur l'actif de la dite succession du feu sieur Llorente;

//

Et vous ferez justice.

Ainsi il est signé au bas de la dite requête, Darlu.

(Designación de Naudin para consultar al Procurador del Rey)

Vu par le Tribunal la dite requête et la demande y contenue; l'ordonnance de monsieur Farry en date du vingt décembre dernier, portant ${ }^{438}$;

$\mathrm{Vu}$ la présente requête, le jugement du dix février mil huit cent vingt sept ensemble à l'acte de liquidation ci-joint;

Disons que les pièces seront communiquées

//

à monsieur procureur du Roi et commettons monsieur Naudin, juge, pour faire son rapport au premier jour.

Fait en la Chambre du Conseil le vingt décembre mil huit cent vingt sept.

Ainsi il est signé au bas de la dite ordonnance, Farry.

(Respuesta del Procurador del Rey)

Et les conclusions par écrit de monsieur le procureur du Roi, en date du vingt deux du même mois de décembre ainsi conçues;

Le Procureur du Roi, considérant que l'opération est régulière en //

la forme et juste au fonds n'empêche l'homologation demandée, à la charge toutefois de la faire prononcer contradictoirement avec le sieur Ruidíaz, qui sans ${ }^{439}$ contester la liquidation lors de sa comparution ne l'a pas non plus approuvée.

Paris, ce vingt deux décembre mil huit cent vingt sept.

Ainsi il est signé au bas des dites conclusions,

Debelleynce

(Sentencia de homologación) Vu également par le Tribunal, la liquidation dont l'homologation est demandée;

//

\footnotetext{
436 Repetida la palabra $d u$.

${ }^{437}$ Plural de icelui, icelle $=$ celui, celle .

438 Correspondiente. Requête et demande-ordonnance portant (la reponse)

439 Tachada del tenor del documento la palabra sera, una llamada remite al margen del documento donde se lee sans, corrección debidamente validada por la rúbrica de Gautier.
}

Inquisidores contra la Inquisición

Hispania Sacra 55 (2003) 
ouis monsieur Naudin, juge, en son rapport; maître Darlu, avoué, dans sa demande; ensemble monsieur le Procureur du Roi, en ses conclusions; tout vu et considéré; et après qu'il en a été délibéré conformément à la loi;

le Tribunal jugeant en première ressort;

attendu que le sieur Ruidíaz a comparu par-devant maître Corbin, notaire, pour prendre connaissance du Procès Verbal de

/I

liquidation par lui dressé;

attendu qu'après la lecture par lui, qui lui a été donnée par le notaire, le dit sieur Ruidíaz a déclaré que sans approuver ni contester le dit Procès Verbal de

/I

liquidation, il ne s'opposait pas à ce que l'homologation en fut demandée et qu'il a signé ce Procès Verbal;

attendu qu'aux termes des articles huit cent trente sept du Code Civil, et neuf cent soixante et dix-sept du Code de Procédure Civile les dires et difficultés que les parties peuvent élever contre la liquidation doivent

II

l'être par-devant le notaire qui doit en rédiger le Procès Verbal, pour être par lui déposé au Greffe du Tribunal;

attendu que quand il ne s'est élevé aucunes difficultés, le notaire doit, suivant les dispositions de l'article neuf cent quatre-vingt et un du Code de Procédure Civile, remettre le Procès Verbal à la partie la plus diligente pour en poursuivre l'homologation;

que la loi ne prescrit d'appeler les parties intéressées à l'homologation, que dans le cas où /I

elles n'ont pas comparu à la clôture du procès verbal chez le notaire;

qu'ainsi, il n'y pas lieu à appeler le sieur Ruidiaz, qui a comparu et qui a signé le procès verbal sans élever contestations;

attendu que l'opération est régulière en la forme et conforme aux droits respectifs des dites parties;

homologué le procès verbal de liquidation de la succession du sieur Llorente, dressé par maître Corbin, notaire;

.ordonne

II

en conséquence qu'il sera exécuté suivant sa forme et teneur.

Fait et jugé par messieurs Moreau, président, Guillon d'Assas et Naudin, juges, le quatre janvier mil huit cent vingt huit.

Mandons et ordonnons à tous huissiers sur ce requis, de mettre le dit jugement à exécution; à nos procureurs généraux et à nos procureurs près les tribunaux civils de première instance, d'y tenir la main à tous commandans $\left(\right.$ sic $\left.{ }^{440}\right)$ et officiers de la force publique de prêter main forte lorsque ils

/I

(dos timbres legales) en seront légalement requis.

${ }^{440}$ Por commandants 
En foi de quoi la minute du dit jugement a été signée par le Président, le Juge rapporteur et le Greffier.

Enregistré à Paris le huit janvier mil huit cent vingt huit, folio six, case $1^{\text {er }}$. Reçu cinq francs 10 centimes, dixième compris.

Ainsi signé,

Collationné, Maire

Rayé deux mots nuls (sigue a esta advertencia la rúbrica de validación de Gautier)

Par le Tribunal

(firma y rúbrica de:) Gautier

\section{G. Minuta del «Exploit» del «huissier» Couturier}

L'an mil huit cent vingt sept huit le douze Janvier à la requête de $\mathrm{M}^{\mathrm{r}}$ Michel Barré, employé au Trésor Royal, deméurant à Paris, rue neuve Saint Roch ${ }^{\circ} 8$ (llamada que remite al margen), ci devant et actuellement rue du Dauphine, $\mathrm{n}^{\circ} 14$ (concluye la añadidura al margen con las dos rúbricas de validación), agissant au nom et comme tuteur de demoiselle Antoinette Elisa Llorente, fille mineure naturelle du feu sieur Jean Antoine Llorente décédé à Madrid en Espagne dans le $10^{441}$ mars de $1822(\mathrm{sic})^{442}$, qualité à laquelle il a été nommé par délibération du conseil de famille de la dite mineure, reçu par $\mathrm{M}^{\mathrm{e}}$ le Juge de Paix du Canton de Neuilly le six janvier 1824, pour lequel sieur Barré domicile est élu en l'étude de $\mathrm{M}^{\mathrm{e}}$ Darlu près le Tribunal de première instance du Département de la Seine séant à Paris, y sise rue Sainte Anne $n^{\circ} 13, j^{\prime}$ 'ai Gabriel Marie Couturier, huissier près le Tribunal Civil du Département de la Seine séant à Paris, y dans rue de la Jussienne $n^{o} 11$, patenté le 29, Marc d'or $n^{0} 29,3^{e}$ classe $^{443}$, soussigné, signifié et, avec celle des présentes, laissé copie a $\mathrm{M}^{\mathrm{r}}$ Alexandre Fernández Ruidíaz, négociant demeurant à Paris, rue Notre Dame des Victoires $n^{\circ} 40$, en son domicile en parlant à la portière de la dite maison ainsi déclarée $e^{444}$, d'un jugement rendu par la Chambre du Conseil de la première Chambre du Tribunal Civil de première instance du Département de la Seine, séant au Palais de Justice à Paris, le quatre janvier, présent mois, dûment en forme exécutoire, enregistré. Le dit jugement contenant homologation du procès verbal, de liquidation de la succession du sieur Llorente dressé par $\mathrm{M}^{\mathrm{e}}$ Corbin, notaire à Paris les vingt cinq mai, et trois octobre mil huit cent vingt sept.

À ce que du contenu au dit jugement le dit sieur Ruidíaz n'ignore, je lui ai, étant et parlant comme dit est, laissé copie tant du dit jugement que du présent dont le coût est de deux francs non compris copie de pièces et déboursés.

\section{(Al margen) Original}

${ }^{441}$ La pequeña cifra es dudosamente legible.

442

443 Las palabras en cursiva están escritas en el texto de la misma mano de Couturier.

${ }^{444}$ Escritas de la mano de Couturier.

Inquisidores contra la Inquisición Hispania Sacra 55 (2003) 


\section{(Firma y rúbrica de:) Couturier}

Enregistré à Paris le quatorze janvier 1828. Reçu deux francs vingt centimes (Firma y rúbrica de): Bruny

\section{H. Acta de pago al Notario Marchoux}

Et le vingt sept février mil huit cent vingt huit

Par-devant $\mathrm{M}^{\mathrm{e}}$ Corbin et son collègue, notaires à Paris, soussignés, est comparu $\mathrm{M}^{\mathrm{r}}$ Michel Barré employé demeurant à Paris rue neuve Saint Roch $\mathrm{n}^{\circ} 8$, agissant comme tuteur de la mineure Antoinette Elisabeth (sic) Llorente

lequel a reconnu avoir reçu de M. Louis Auguste Marchoux, ancien notaire à Paris y demeurant rue de la Chaussée d'Antin $\mathrm{n}^{\mathrm{O}} 3$, la somme de deux cent cinquante neuf francs cinquante cinq centimes formant le reliquat du compte des rentes et dépenses faites par M. Marchoux pour la succession de feu M. Jean Antoine Llorente; laquelle somme a été abandonnée à la dite mineure aux termes du partage de cette succession fait par $\mathrm{M}^{\mathrm{e}}$ Corbin comme à cet effet le trois octobre mil huit cent vingt sept approuvé par les parties suivant procès verbal dressé le même jour par le dit $\mathrm{M}^{\mathrm{e}}$ Corbin le tout enregistré et homologué. (Al pie de la página está presente la rúbrica de Gruvy) // Dont quittance

Fait et passé à Paris en l'étude les jour, mois et an sus dits et a signé avec les notaires après lecture faite

(Nota al margen) Rayé trois mots comme nuls (siguen las rúbricas de validación de Corbin, Morineau, Barré y Cruvy)

(Firman y rubrican alfinal del documento:) Barré, Corbin, Morineau

Enregistré à Paris le quatorze mars 1828 folio $21, \mathrm{~N}^{\circ}$ Case 1 et 9 (?) Reçu un franc . quarante trois centimes dixième compris

(Firma y rúbrica de:) Cruvy

(Al margen, la suma del costo y de la décima:)

1.30

0.13

445 La abreviatura Rep está en imprenta con tipos de elegante letra inglesa. La abreviatura $M^{x}$ (lectura dudosa) ha sido escrita a mano. Quizás la abreviatura signifique: Repayement Marchoux 